\title{
AVALIAÇÃO DO DESENVOLVIMENTO DE LEVEDURAS CONTAMINANTES DE PROCESSOS DE PRODUÇÃO DE ETANOL POR PARÂMETROS NÃO CONVENCIONAIS
}

\author{
MARIA ESTELA DA SLVA \\ Bióloga
}

Orientador: Prof. Dr. ANTONIO JOAQUIM DE OLIVEIRA

Dissertação apresentada à Escola Superior de Agricultura "Luiz de Queiroz", da Universidade de São Paulo, para obtenção do título de Mestre em Agronomia, Área de Concentração: Microbiologia Agrícola.

P IR A C I C A B A

Estado de São Paulo - Brasil

Agosto - 1994 
Ficha catalagrafica preparada pela Seçáa de Livros da Divisào de Biblioteca e Documentạ̧a - FCLQ/USF

\section{Silva, Maria Estela da}

$5586 a$ Avaliaça da desenvolvimento de leveduras contami
nantes de processos de producto de etanol por parame tros năo convencionais. Firacicaba, 1994. $70 \mathrm{p}$. ilus.

Diss. (Mestre) - ESALQ

Eibliagrafia.

1. Etanal 2. Fermentaçăa etambica 3. Levedura I. Escola Superior de Agricultura Luiz de Gueiroz, Firacicaba 


\section{AVALIAČ̃̃ DO DESENVOLVIMENTO DE LEVEDURAS CONTAMINANTES DE PROCESSOS DE PRODUÇÃO DE ETANOL POR PARÂMETROS NÃO CONVENCIONAIS}

MARIA ESTELA DA SILVA

Aprovada em: 30.09.1994

Comissão Julgadora:

Prof. Dr. Antonio Joaquim de Oliveira ESALQ/USP

Prof. Dr. Luiz Gonzaga do Prado Filho ESALQ/USP

Profa . Dra ${ }^{\mathrm{a}}$. Dejanira de Franceschi de Angelis IB/UNESP

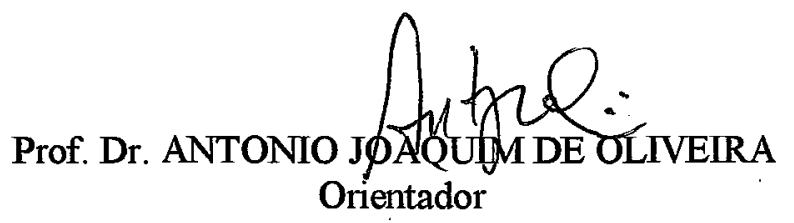


Los meus pais,

\title{
Paulo a Antonia
}

\author{
e especialmente meu tio, \\ Antonio Carlos
}

Qferecgo

"É muito methor arriscar coisas grandiosas, alcancar triunfos e glórias, mesmo expondo-se à derrota, do que formar fila com os polures de espírito que nem gozam muito, nem sofrem muito porque vivem nessa penumbra ausente que não conhece vitória nem derrota."

A todos agueles que não têm oportunidade de estudar

Dedico 


\section{AGRADECIMENTOS}

- Ao Dr. Antonio Joaquim de Oliveira, pela oportunidade, orientação e amizade durante a realização deste trabalho.

- À bióloga Maria da Graça S. Andrietta pela colaboração na elaboração deste projeto.

- Ao Departamento de Ciência e Tecnologia Agroindustrial da ESALQ/USP.

- A FERMENTEC S/C Ltda. por ceder as culturas.

- Aos professores: Dr. Jorge Horii, Dra. Aline Pizzirani-Kleiner e Dra. Siu Mui Tsai Saito pela atenção e valiosas sugestões.

- À CAPES pelo auxílio financeiro.

- À Assessoria Estatística do Depto. de Matemática da ESALQ/USP, na pessoa do Prof. Dr. Décio Barbin e Marcelo Correa Alves (CIAGRI) pela orientação nas análises estatísticas.

- À bióloga Silvana Furlan pelo auxílio nas fases iniciais deste trabalho.

- Aos colegas Cleomar, Carlos Eduardo, Valmir e Silvana Albertini, pela amizade, colaboração e valiosa convivência.

- Ao Departamento de Química, nas pessoas do Prof. Dr. Luiz Carlos Basso, Luis Lucatti e Admir de Almeida Campos, pela orientação nas análises.

- À Bibliotecária Beatriz Helena Giongo pela atenção prestada à revisão bibliográfica.

- Aos colegas, professores e funcionários do curso de microbiologia agrícola, pela atenção, amizade e contribuição à minha formação profissional.

- Ao Coordenador do Curso de Microbiologia Agrícola, Prof. Dr. Luiz Gonzaga do Prado Filho, pela amizade e incentivo durante o curso.

- À Copersucar, na pessoa do Sr. Luiz Hiroshi Koshimizu.

- À Vera Maria Queccini, pela colaboração na tradução do resumo.

- A amiga Rosilene Naves Domingos, por tornar nossas horas mais alegres e ao amigo Ivo Mottin Demiate pelo incentivo.

- A todos que direta ou indiretamente contribuiram na execução deste trabalho.

- A Deus, por permitir que tudo fosse realizado. 


\section{SUMÁRIO}

Página

LISTA DE TABELAS.................................................................................

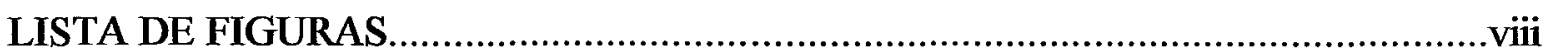

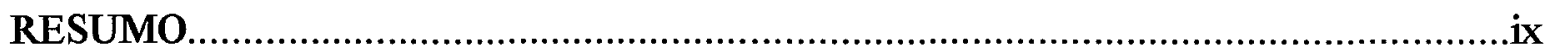

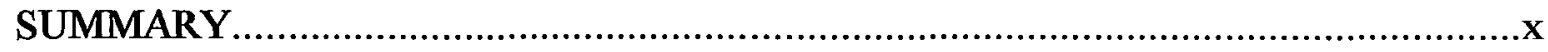

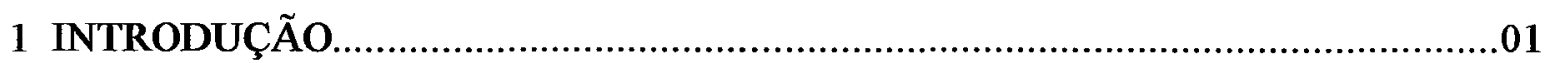

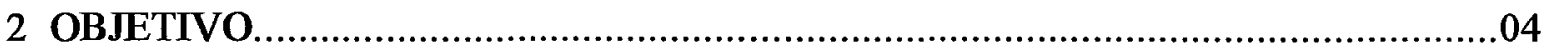

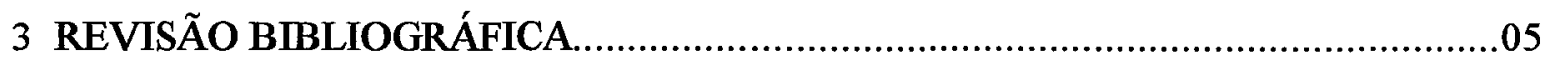

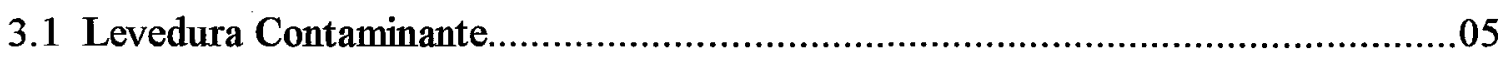

3.2 Estudo do comportamento de várias leveduras............................................06

3.3 Métodos para detecção de levedura contaminante...........................................07

3.3.1 Meios diferenciais.................................................................... 07

3.3.2 Assimilação e fermentação de carbono................................................ 08

3.3.3 Fator killer.......................................................................... 08

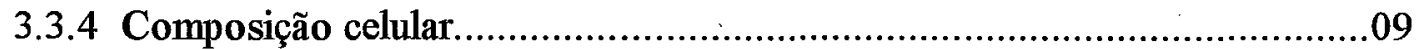

3.4 Cinética de Crescimento..................................................................... 10

3.4.1 Análise dos dados de crescimento.............................................. 11

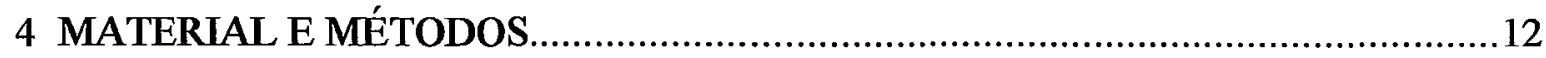

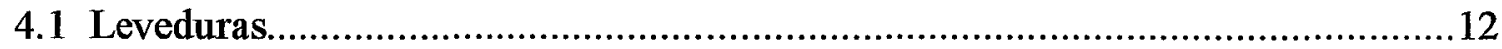

4.2 Meios de propagação e fermentação.........................................................12

4.2.1 Composição meio sintético - meio 1 ................................................. 12

4.2.2 Composição meio de HTM - meio 2 .................................................. 12

4.2.3 Composição meio de HTM - meio 3.............................................. 13

4.3 Determinação de ART no HTM, no mosto e no vinho.....................................13

4.4 Determinação do pH no mosto............................................................ 13

4.5 Determinação da viabilidade celular........................................................... 13

4.6 Determinação do teor alcoólico no vinho...................................................... 13

4.7 Determinação de parâmetros cinéticos (rendimento de biomassa e etanol)...........14

4.7.1 Propagação.......................................................................... 14

4.7.1.1 Método para determinação da massa seca...............................14

4.7.2 Fermentação..............................................................................15

4.7.3 Determinação da massa de açúcar consumida na fermentação (MACF).....16 
4.7.4 Determinação da massa de etanol produzida na fermentação (MEPF)......17

4.7.5 Determinação da massa celular produzida na fermentação (MCPF)...........19

4.7.6 Determinação do rendimento em etanol ........................................19

4.7.7 Determinação do rendimento em massa celular.....................................19

4.8 Determinação da velocidade específica de crescimento máxima...........................20

4.8.1 Curva de calibração utilizada nos ensaios para determinação da massa seca............................................................................22

4.9 Delineamento Experimental e Análise Estatística.........................................24

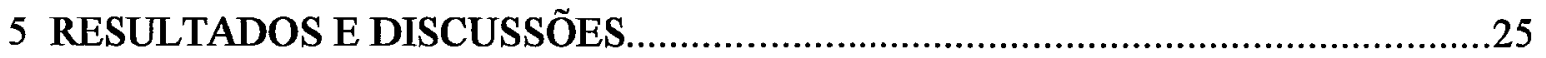

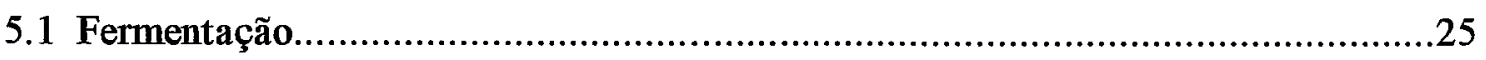

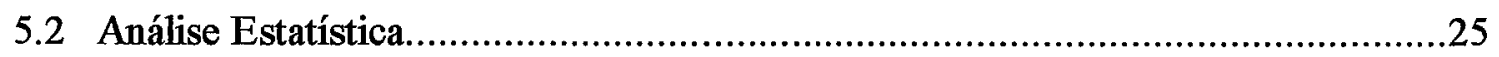

5.3 Cinética de Crescimento Celular................................................................... 31

6 CONCLUSÕES.................................................................................41

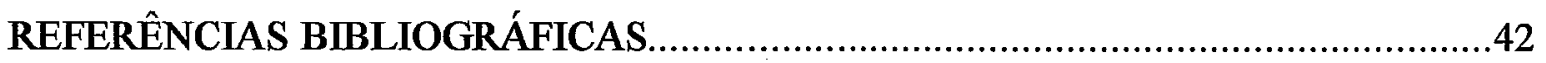

APÊNDICE 1 - Curvas de Calibração utilizadas nos ensaios de crescimento celular........50

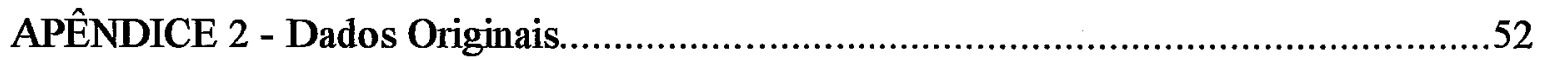

APÊNDICE 3 - Dados de Crescimento Celular.........................................................67 
1 Valores médios dos ensaios de fermentação: massa celular (g), massa de etanol $(\mathrm{g})$, rendimento celular $(\mathrm{g} / \mathrm{g})$, rendimento em etanol (g/g), pH final, viabilidade celular (\%), ART meio $3(\%)$, açúcar consumido (\%).

2 Teste Tukey para médias dos valores do consumo de açúcar durante os ensaios de fermentação (\%).

Teste Tukey para médias dos valores da formação de massa de etanol $(\mathrm{g})$.

Análise da Variância dos valores médios de formação de massa de etanol.

Teste Tukey para médias dos valores da formação de massa celular (g).

7 Análise da Variância dos valores médios da formação de massa celular.

8 Teste Tukey para médias dos valores do rendimento em etanol (g/g).

9 Análise da Variância dos valores médios do rendimento em etanol.

10 Teste Tukey para médias dos valores do rendimento celular (g/g).

11 Análise da Variância dos valores médios do rendimento celular. .30

12 Velocidade específica de crescimento máxima ( $\left.\mu_{\operatorname{máx}}\right)$ 


\section{LISTA DE FIGURAS}

Número

Título

Página

1 Esquema do procedimento experimental para determinação dos rendimentos em etanol e biomassa. 18

2 Curva de crescimento microbiano, onde a inclinação da parte linear $(\mathrm{m})$ é o valor de $\mu_{\text {máx }}$

3 Esquema do procedimento experimental para determinação de $\mu_{\text {máx }}$

4 Curva de crescimento celular Tratamento 1

5 Curva de crescimento celular Tratamento 2 .33

6 Curva de crescimento celular Tratamento 3. 34

7 Curva de crescimento celular Tratamento 4 34

8 Curva de crescimento celular Tratamento 5. .35

9 Curva de crescimento celular Tratamento 6. 35

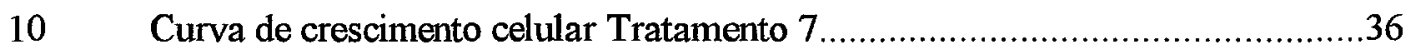

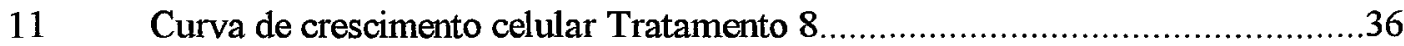

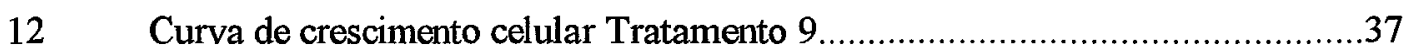

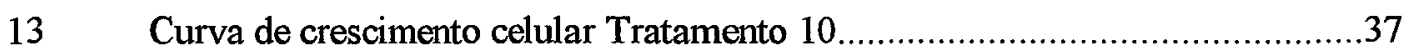

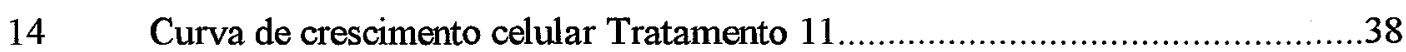

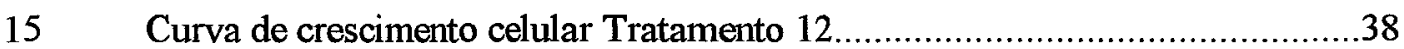

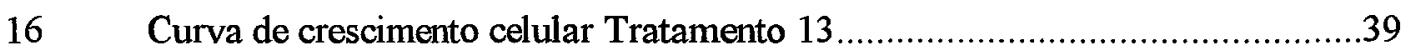

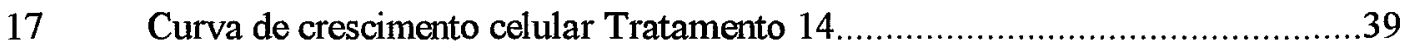

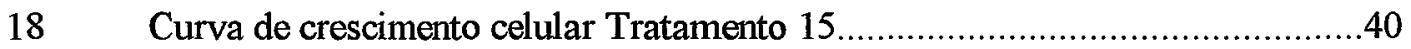




\title{
AVALIAÇÃO DO DESENVOLVIMENTO DE LEVEDURAS CONTAMINANTES DE PROCESSOS DE PRODUÇÃo DE ETANOL POR PARÂMETROS NÃO CONVENCIONAIS
}

\author{
Autora: MARIA ESTELA DA SILVA \\ Orientador: Prof. Dr. ANTONIO JOAQUIM DE OLIVETRA
}

\section{RESUMO}

O presente trabalho foi realizado com o objetivo de acompanhar por parâmetros não convencionais, como velocidade específica de crescimento máxima, rendimento de biomassa e rendimento em etanol, durante a fermentação, sob as mesmas condições de temperatura, agitação, pH e concentração de sacarose, as características do comportamento de quatro linhagens de leveduras, em condições de laboratório. As leveduras foram multiplicadas em meio anaeróbio, em mosto de HTM (High Tests Molasses), empregando-se Saccharomyces cerevisiae (fermento prensado Fleischmann), Saccharomyces cerevisiae M-300-A (TA), Saccharomyces uvarum IZ-1904 e Candida krusei. Para avaliar o comportamento das leveduras, após cada ensaio de fermentação e propagação, foram retiradas amostras para determinações de $\mathrm{pH}$, viabilidade celular, açúcares redutores totais (ART), etanol e massa celular. Dos resultados obtidos, observouse que a levedura Candida krusei apresentou menor formação de massa de etanol, como também menor consumo de açúcar, indicando não ser uma boa levedura para fermentações industriais. Quanto ao rendimento em etanol não houve diferença significativa entre nenhum tratamento. A levedura Candida krusei apresentou um maior rendimento de células, podendo estar relacionado com a pouca formação de massa de etanol. Para a velocidade específica de crescimento máxima, constatou-se ser possível verificar a presença de leveduras contaminantes durante o processo de fermentação, em apenas 5 horas. 
THE CONTAMINATING YEAST GROWTH EVALUATION, IN THE ETHANOL PROCESSING BY NON-CONVENTIONAL PARAMETERS

Author: MARIA ESTELA DA SILVA

Adviser: Prof. Dr. ANTONIO JOAQUIM DE OLIVEIRA

\section{SUMMARY}

The actual work has been carried out aiming to follow the behavior characteristics of four yeast strains under laboratory conditions by non-conventional parameters like: maximum specific growth rate, biomass and ethanol yielding, during the fermentation under the same temperature, steering, $\mathrm{pH}$ and sucrose concentration conditions. The yeasts have been grown on anaerobic media, on must from HTM (High Test Molasses), using Saccharomyces cerevisiae (pressed Fleischmann ferment), Saccharomyces cerevisiae M-300-A (TA), Saccharomyces uvarum IZ-1904 and Candida krusei. In order evaluate the yeasts behavior, samples have been taken after each fermentation on propagation assay to determine $\mathrm{pH}$, cellular viability, total reducing sugars (TRS), ethanol and cell mass. From the results, it has been observed that the yeast Candida krusei showed the lowest ethanol production, as well as the lowest sugar consumption, proving not to be a suitable yeast for industrial fermentations. As for as ethanol yielding has been concerned, there has been no significant difference among the trials. The yeast Candida krusei had the largest biomass cell yield, so that it could be related with the low ethanol mass production. It has been possible to verify the presence of contaminating yeasts during the fermentation process by the maximum specific growth rate within only five hours. 


\section{INTRODUÇÃO}

A fermentação etanólica é um processo microbiológico, que pode ser conduzido por diferentes microrganismos, denominados taxonomicamente como leveduras. As operações de fabricação de etanol estão sujeitas a problemas tecnológicos, assim como problemas de natureza microbiana. No Brasil, o etanol é produzido por via fermentativa, e as indústrias alcooleiras empregam a prática da utilização de inóculos nos processos fermentativos industriais, onde a partir disto, observou-se a ocorrência de microrganismos indesejáveis para o processo. É prática comum, em indústrias cervejeiras, o uso de inóculos selecionados para as fermentações (STANBURY \& WHITAKER, 1984), porém, segundo estes autores, os perigos inerentes nesta prática são a introdução de contaminantes e a degeneração de linhagens, sendo a mais comum, uma mudança no grau de floculação e capacidade de atenuação das leveduras.

Em geral, pode-se dizer que qualquer espécie de microrganismo pode vir a contaminar fermentações alcoólicas durante as operações de processamento, mas somente algumas espécies são capazes de nelas se desenvolverem. $\mathrm{Na}$ indústria alcooleira, ao iniciar-se cada safra, o levedo é submetido a um processo de multiplicação e revigoramento no sentido de se obterem quantidades adequadas à condução do processo.

O desenvolvimento de microrganismos contaminantes de fermentação depende de vários fatores, como $\mathrm{pH}$, falta de assepsia nos equipamentos, temperatura, entre outros e segundo SHEHATA (1960) a quantidade de leveduras presentes na fermentação é elevada e diversificada e muitas destas leveduras podem ser consideradas contaminantes e se fazem presente no processo como um todo.

A contaminação é normal na indústria alcooleira, porque não se trabalha em condições assépticas, mas mesmo assim, as fermentações são produtivas e eficientes. Os problemas surgem quando leveduras estranhas, ocorrem em proporções elevadas e não contribuem para o bom funcionamento da fermentação. 
Após a criteriosa escolha e preparo inicial, o levedo sofre inúmeras reciclagens, durante as quais está sujeito a sofrer contaminações por outros microrganismos, tornando necessário o permanente monitoramento microbiológico. Com a adoção desta prática de fermentação inoculada, surgiu um novo conceito, o de levedura contaminante, que é aquela que pode ou não contribuir para o bom funcionamento da fermentação.

A identificação de leveduras consiste em caracterizá-las de forma inequívoca e as distinguir, mesmo quando suas células estão misturadas. As metodologias aplicadas à identificação, tem a finalidade principal de classificar taxonomicamente as espécies e envolvem procedimentos como o isolamento do ambiente, determinação de propriedades morfológicas e fisiológicas, descrição e comparação com organismos padrões, e ocasionalmente, avaliação de propriedades tecnológicas.

As limitações metodológicas da classificação, que impõe rígida observância das condições em que se avaliam as propriedades das leveduras, podem produzir resultados insatisfatórios. Por este motivo deve-se considerar que qualquer variabilidade de resultados, obtidos pela técnica usada ou pela variação de linhagens, podem resultar em identificação equivocada. Assim, existem espécies antes distintas e que atualmente, com base em critérios genéticos, são consideradas a mesma espécie.

Devido às limitações metodológicas, multiplicaram-se os sistemas de identificação, onde os métodos compreendem desde simples observações visuais e testes bioquímicos padrões, até o uso de técnicas sofisticadas. Citam-se a sorologia (TSUCHIYA et $a l, 1965$ ), conteúdo de bases nitrogenadas e hibridização de DNA (KURTZMAN \& PHAFF, 1987), análise da parede celular por ressonância nuclear magnética (GORIN \& SPENCER, 1970), análise do sistema de coenzima $Q$ (YAMADA et al, 1976), propriedades de ácidos graxos (BENDOVÁ et al, 1991), movimento de prótons e transporte de açúcares (KILIAN et al, 1991), separação de cromossomos por eletroforese (SHEEHAN \& WEISS, 1991), bioluminescência (MILLER \& GALSTON, 1989), efeito inibitório de diferentes compostos (SIMPSON et al, 1992), propriedades genéticas modificáveis (THORNTON \& BUNKER, 1989), métodos eletrônicos, onde é possível fazer o controle de qualidade com quantidades mínimas de amostras de vinho, podendo-se detectar leveduras contaminantes (HENSCHKE \& THOMAS, 1988; DAY, 1987), etc. 
A eliminação de contaminantes requer muita pesquisa no sentido de se descobrir as fontes de contaminação e depende também da experiência e bom senso do microbiologista. A indústria alcooleira, apesar da importância cada vez maior dada ao fermento, ressente-se da falta de metodologias adequadas à identificação rápida e precisa. De acordo com TAVARES (1992), é imprescindível a manutenção da pureza dos inóculos industriais, fator relevante para a qualidade do produto e produtividade. A partir disto, a Engenharia Genética vem desenvolvendo novas linhagens de leveduras, as quais tornam a fermentação mais eficiente (HINCHLIFFE, 1992; TAVARES, 1992; STEELE \& STOWERS, 1991).

Considerando estes fatos, o presente trabalho visou avaliar comparativamente a produção de massa de etanol, massa celular formada, consumo de açúcar e rendimento de etanol e células, e também a velocidade específica de crescimento máxima, de quatro leveduras, partindo de culturas puras e mistas, sob as mesmas condições de concentração de açúcares redutores totais, temperatura, agitação, pH e nutrientes. 


\section{OBJETIVO}

Este trabalho teve como objetivo acompanhar por parâmetros, como velocidade específica de crescimento máxima, rendimento de biomassa e rendimento em etanol, as características do comportamento de quatro linhagens de leveduras em cultura pura e mista, em condições de laboratório, para assim, determinar a presença de leveduras contaminantes. 


\section{REVISÃo BIBLIOGRÁFICA}

\subsection{Levedura Contaminante}

Leveduras contaminantes são causas de "defeitos" na fermentação. A contaminação por leveduras é um fato na maioria das indústrias produtoras de álcool e que pode ser agravado dependendo da maneira de se conduzir o processo operacional. Suas propriedades bioquímicas causam problemas no sabor, floculação e turbidez, dificultando a fermentação e algumas vezes acompanhada por vigorosa pósfermentação. Pode ocorrer também, a formação de uma película superficial, devido à contaminação por Pichia e Candida, alterações no sabor e aroma, devidas à produção de ácidos, particularmente por Brettanomyces, e a super-atenuação, causada especialmente por Saccharomyces diastaticus (OLIVEIRA, 1987). PHAFF et al (1978) descreveram leveduras contaminantes como organismos que produzem mudanças indesejáveis no produto durante o processo de fermentação.

Conforme TAVARES (1992), levedura selvagem é aquela que, em geral, pertencente a certa espécie, ocorre em proporção elevada chegando, inclusive, a dominar o fermento original. $O$ mesmo autor relata que inexistem medidas preventivas, ou de controle de contaminação por leveduras e os métodos disponíveis, como modificações de procedimentos operacionais e emprego de antissépticos, são ineficazes para conter a sua proliferação sem que seja afetado o fermento propagado.

Os gêneros de leveduras que podem estar associados à selvagem nos processos fermentativos para a produção de etanol, são segundo VAN OEVELEN $e t$ al (1977): Brettanomyces sp, Candida, Debaryomyces, Hansenula, Pichia, Schizosaccharomyces, Torulopsis e Dekkera e BARNETT et al (1983) incluem ainda os gêneros Hanseniaspora, Saccharomyces e Zigosaccharomyces.

GILLILAND (1971) explica que no processo de fermentação com cultura pura e cana esterilizada, a levedura pode sofrer mutação e tornar a fermentação 
contaminada. Segundo este autor, o mutante difere da cultura inicial na capacidade de flocular e se esta diferença der ao mutante a vantagem seletiva, então pode ocorrer uma mudança gradual das características da fermentação, sendo que o mutante aumenta em proporção a cada fermentação.

CAMPBELL (1987a), relata que o inóculo isolado de equipamentos da indústria cervejeira, e outras leveduras que aparecem no processo devido à chance de contaminação, podem não ser prejudiciais à fermentação.

\subsection{Estudo do comportamento de várias leveduras}

Diversos trabalhos tem sido realizados para se estudar as características e o comportamento das várias leveduras utilizadas para fermentação industrial, que pode ser influenciado por fatores genéticos e ambientais (HARRISON, 1971; FREDRICKSON, 1977), assim como a composição química da levedura é sensível à ambientes químicos e físicos nos quais as células estão crescendo (WILSON \& McLEOD, 1976).

HAUKELI \& LIE (1971) estudaram fatores de crescimento para seis linhagens de leveduras, GUINARD \& LEWIS (1993) verificaram o fenômeno de aglomeração na levedura Saccharomyces cerevisiae, WALSH \& MARTIN (1977), compararam o crescimento de Saccharomyces cerevisiae e Saccharomyces uvarum sob o efeito da temperatura, VISSER et al (1990) estudaram a capacidade das leveduras crescerem em condições anaeróbias, HARALDSON \& BJÖRLING (1981) separaram vinte linhagens e observaram o efeito da temperatura sobre a produtividade e níveis não-inibitórios de etanol, GUTIERREZ (1989), comparou o desempenho da levedura Saccharomyces uvarum IZ-1904, e das linhagens de $S$. cerevisiae M-300-A, Fleischmann, IZ-270 e Itaiquara, em diferentes condições de temperatura, concentração de sacarose, pH, fontes de nitrogênio e na presença de inibidores 2,4dinitrofenol, isoniazida e arsenito de sódio, ALVES (1993) avaliou o comportamento de várias leveduras com relação a diversos fatores como temperatura, $\mathrm{pH}$, teores excessivos de potássio, diferentes condições de substrato e diferentes fontes nitrogenadas, e muitos outros trabalhos vêm sendo realizados para que se conheça melhor o desempenho de tais leveduras durante o processo fermentativo. 


\subsection{Métodos para deteç̧ão de levedura contaminante}

\subsubsection{Meios diferenciais}

A contagem em placas, apesar de ser um método mais sensível e acusar apenas os organismos viáveis, possui uma série de dificuldades, entre as quais a deteç̧ão de proporções relativamente pequenas de outros organismos na presença de grande número de cultura de leveduras. Sendo assim, desenvolveram-se métodos de contagem em placas usando meios diferenciais e técnicas que suprimissem o crescimento de cultura de leveduras e, ao mesmo tempo, não afetassem o crescimento de contaminantes.

Quando são utilizados meios de cultivo seletivos, esses possuem propriedades que vão inibir ou selecionar determinado tipo de levedura. Segundo CAMPBELL (1987b), os meios mais utilizados para este fim são: a) meios inibidores, onde as leveduras selvagens crescem, ficando a levedura de processo inibida, sendo mais utilizados os meios contendo cristal violeta, actidiona, fucsina e sulfito e b) meios seletivos, onde são adicionados ao meio fontes de carbono que apenas as leveduras contaminantes são capazes de utilizar como amido ou xilose por exemplo.

RODRIGUEZ (1987), sugere para identificação de leveduras selvagens quatro diferentes meios de cultivo sendo esses adicionados de lisina, actidiona e cloreto de sódio e o último livre de pantotenato.

Alguns métodos permitem reconhecer leveduras contaminantes, como o método da "colônia gigante", onde pode-se observar a morfologia da colônia (RICHARDS, 1967; GILLILAND, 1971) e o método de coloração de colônias (HALL, 1971). Pela morfologia das colônias também pode-se distingüir linhagens de leveduras em cultura mista (HOWARD, 1971). Segundo DAY \& MEYLING (1983), muitos métodos são propostos, porém, poucos tem aplicação prática. Cada novo método tem sua limitação e alguns não são adequados à laboratórios de controle de qualidade. 


\subsubsection{Assimilação e fermentação de carbono}

Assimilação e fermentação de fontes de carbono são comumente utilizadas na identificação de leveduras (BARNETT et al, 1983; QUAIN, 1986), entretanto esse teste envolve grande quantidade de fontes a serem testadas o que o torna inviável como prática de rotina nas unidades industriais.

GRIFFITHS (1981), sugere uma metodologia alternativa que envolve um número menor de fontes de carbono a serem testadas que os métodos convencionais, e pode-se diferenciar, pelo menos a nível de gênero, em aproximadamente 72 horas.

DEGRÉ et al (1989), testaram a utilização de um "kit" disponível no mercado, onde uma série de açúcares podem ser testados simultaneamente, o que facilita o emprego desta técnica.

CAMPBELL (1987b), cita o uso de meios seletivos com ágar citrato, ágar xilose, etc., para leveduras capazes de utilizar somente fontes de carbono suplementadas.

\subsubsection{Fator Killer}

A denominação levedura "killer" é dada a leveduras capazes de produzir e excretar no meio uma toxina, inócua a elas mas que pode matar leveduras sensíveis presentes no meio (WOODS \& BEVAN, 1968; SOMERS \& BEVAN, 1969). Existem ainda as leveduras denominadas neutras, as quais não produzem esta toxina, mas que entretanto são indiferentes a ela (SOMERS \& BEVAN, 1969).

A caracterização de leveduras que apresentam fator "killer" positivo tem importância nas unidades industriais, e de acordo com BUSSEY (1981), as toxinas "killer" são secretadas durante a fase exponencial de crescimento da levedura, e apenas níveis de $6 \times 10^{3}$ são suficientes para matar células sensíveis. MAULE \& THOMAS (1973) acreditam que leveduras selvagens as quais são "killer" positivas podem apresentar problemas em fermentações contínuas, uma vez que a atividade máxima da toxina é alcançada em $\mathrm{pH}$ de 3,8 à 4,2 , situação esta que é encontrada neste tipo de processo. 
SATO et al (1993), sugerem como metodologia para se testar leveduras selvagens quanto ao fator "killer", a utilização de um método modificado, onde baseiase na técnica de azul de metileno-ágar e uma linhagem conhecidamente sensível a este fator.

Um outro teste seria o uso de linhagens "killer" marcadas, numa cultura mista, que quantifica o efeito de toxinas "killer" em linhagens sensitivas (PETERING et al, 1991).

\subsubsection{Composição celular}

Técnicas modernas, onde padrões determinados de composição celular das diferentes espécies de leveduras são utilizados, permitem a identificação de leveduras através da comparação de sua composição com estes padrões.

TREDOUX et al (1987), sugerem técnica baseada na composição de ácidos graxos. Através da análise via cromatografia gasosa, esses autores separaram as leveduras associadas a indústria produtora de vinho em três grupos e sugerem este tipo de análise como substituta dos métodos convencionais, uma vez que após isolada a levedura, a resposta da análise é obtida na metade do tempo das convencionais. DEGRE et al (1989), colocam como restrição à utilização deste método as condições de crescimento destas células, uma vez que se não houver uma padronização destas o resultado fica comprometido.

VAN VURREN \& MEER (1988), utilizaram padrões de proteínas, e através deste puderam separar leveduras provenientes de cervejarias em três grupos de Saccharomyces cerevisiae. Esta técnica foi testada também por DEGRÉ et al (1989) para leveduras isoladas de fermentações para produção de vinho e por TAVARES et al (1992) para leveduras isoladas de unidades produtoras de álcool.

O material genético, isto é, o DNA tem sido utilizado como recurso para identificação de levedura selvagem. Os métodos mais utilizados são: eletroforese de cromossomos e DNA "fingerprint". Segundo DEGRÉ et al (1989), a técnica "fingerprint" é mais promissora quando comparada a de análise do DNA cromossomal, isto porque com esta primeira técnica é possível especificar a sequência de DNA e a análise de DNA cromossomal fornece apenas o tamanho dos cromossomos. 
TAVARES et al (1992), identificaram leveduras rotineiramente utilizadas como inóculo para fermentação alcoólica utilizando técnicas de eletroforese de proteína e DNA "fingerprint" e concluiu que os dois métodos complementam as técnicas que apenas permitem identificar leveduras de espécies diferentes, abrindo a possibilidade de se distinguir variações do próprio fermento, ou aquelas devido a contaminação, mesmo devido a leveduras com morfologia similar.

\subsection{Cinética de Crescimento}

Quando um microrganismo é introduzido num meio de cultura apropriado, são observadas inúmeras reações, como o consumo de parte ou do total do substrato e dos nutrientes disponíveis no meio, o aumento, por reprodução celular, da massa de microrganismos presentes no meio e, a formação de produtos do metabolismo celular.

Segundo LEVEAU \& BOUIX (1985) este estudo consiste em seguir, em função do tempo (t), a evolução da concentração celular $(X)$, (número de células por unidade de volume) ou biomassa ( $\mathrm{g}$ de matéria seca/unidade de volume) conforme o tipo de microrganismo (unicelular ou filamentoso) e o tipo de método escolhido para seguir o fenômeno, ele desenvolve aí uma atividade relacionada com sua composição e com as condições que o rodeiam.

Pequenas diferenças na composição do meio, variação de temperatura, suplemento de oxigênio e alteração no comportamento de linhagens de leveduras, podem exercer efeitos significantes no crescimento de leveduras durante o processo de fermentação (HAUKELI \& LIE, 1971).

O efeito de nutrientes minerais e vitaminas sobre o crescimento de leveduras foi estudado por NORDSTRÖM $(1963 ; 1964)$ que verificou que quando o crescimento celular foi inibido, o mesmo ocorreu com a formação de éster. 


\subsubsection{Análise dos dados de crescimento}

Quando os valores do logarítimo neperiano da concentração celular são colocados em função do tempo, observa-se que o trecho linear da curva, corresponde à fase exponencial de crescimento, e pode ser representado pela equação:

$$
\begin{aligned}
& \ln X=\ln X_{0}+\text { at } \\
& \text { onde: } \begin{aligned}
X_{0} & =\text { concentração celular no início da fase log } \\
a & =\text { coeficiente angular da reta } \\
t & =\text { tempo }
\end{aligned}
\end{aligned}
$$

ou seja, o coeficiente angular da reta é igual à velocidade específica de crescimento e a tangente à curva, é, em qualquer ponto, igual à velocidade específica de crescimento $\mathrm{e}$ que, na fase exponencial esta tangente é constante e tem seu valor máximo ( $\left.\mu_{\text {máx }}\right)$ (PIRT, 1975; STANBURY \& WHITAKER, 1984). 


\section{MATERIAL E MÉTODOS}

\subsection{Leveduras}

Foram utilizadas quatro linhagens de leveduras nos ensaios de propagação e fermentação: Saccharomyces cerevisiae (fermento prensado Fleischmann), S. cerevisiae M-300-A (TA), S. uvarum IZ-1904 e Candida krusei, todas multiplicadas em laboratório, pertencentes à coleção da FERMENTEC S/C Ltda.

\subsection{Meios de propagação e fermentação}

\subsubsection{Composição meio sintético (meio 1)}

Glicose. $40,0 \mathrm{~g}$

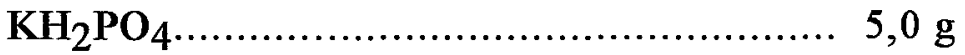

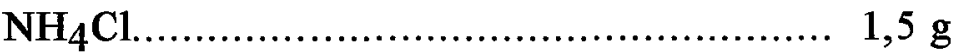

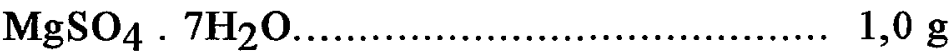

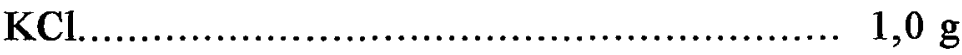

Extrato de levedura.............................. 2,0 g

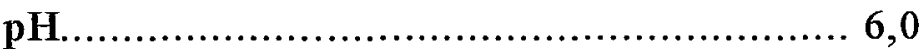

Água destilada q.s.p...............................1.000 ml

Fonte: RODRIGUES (1989)

\subsubsection{Composição meio de HTM (High Test Molasse) (meio 2) - por litro \\ HTM................................................. $140 \mathrm{~g}$ \\ Extrato de levedura.................................. $3 \mathrm{~g}$}




\subsubsection{Composição meio de HTM (High Test Molasse) (meio 3) - por litro}

HTM...........................................200 g

Extrato de levedura.............................. $3 \mathbf{g}$

\subsection{Determinação de ART no HTM, no mosto e no vinho}

O ART dos meios fermentativos foi determinado pelo método de Somogyi e Nelson, adaptado por AMORIM et al (1982).

\subsection{Determinação do pH no mosto}

O pH foi medido em pHmetro modelo Digimed DMPH-2.

\subsection{Determinação da viabilidade celular}

A viabilidade celular foi calculada conforme PIERCE (1970).

\subsection{Determinação do teor alcoólico no vinho}

Para esta determinação, $25 \mathrm{ml}$ do vinho centrifugado foram destilados em microdestilador Kjeldahl adaptado para álcool e a densidade do destilado medida em densímetro digital Anton-Paar modelo DMA-46, segundo AMORIM et al (1982). O teor alcoólico da amostra foi determinado utilizando-se tabelas de correspondência densidade $/ \%$ álcool, à $20^{\circ} \mathrm{C}$, e expresso em álcool \% peso $(\mathrm{p} / \mathrm{p})$. 


\subsection{Determinação de parâmetros cinéticos (rendimento de biomassa e rendimento em etanol)}

Todo o procedimento foi aplicado a cada um dos tratamentos.

\subsubsection{Propagação}

O mosto utilizado para propagação foi preparado à partir de HTM cedido pela Copersucar com uma concentração de Açúcares Redutores Totais (ART) de 75\%. O HTM foi diluído às concentrações de 13 à $15 \%$ de ART (g/100 ml), suplementado com extrato de levedura conforme meio 2. Estes mostos foram esterilizados em autoclave à $1,0 \mathrm{~atm}$ de pressão, à $121^{\circ} \mathrm{C}$ durante 20 minutos. As culturas foram propagadas em frascos de Erlenmayers de $500 \mathrm{ml}$, contendo $200 \mathrm{ml}$ de meio 2 , por incubação em "shaker" à $35 \pm 1^{\circ} \mathrm{C} / 24 \mathrm{hs}$.

Esta fase se dividiu em duas etapas. Primeiro, o "slant" foi transferido para sete tubos de ensaio contendo $5 \mathrm{ml}$ de meio 1 . Estes foram incubados a $35 \pm^{0} \mathrm{C} / 24$ h. A partir disto, cinco destes tubos foram transferidos para Erlenmayer de $500 \mathrm{ml}$ previamente pesado (EPV - para se determinar a massa final de meio fermentado) contendo $200 \mathrm{ml}$ de meio 2. Este foi incubado em "shaker" à $35^{\circ} \mathrm{C} / 24 \mathrm{~h}$. Em seguida, pesou-se o Erlenmayer (EPF - para a determinação da massa final de material fermentado). Ao final, foram retiradas 2 amostras de $10 \mathrm{~g}$ cada para determinação da concentração de massa seca (item 4.7.1.1). O material contido no Erlenmayer foi transferido para tubos de centrífuga e centrifugado à $4000 \mathrm{~g}$ por cinco minutos. $O$ sobrenadante foi coletado e nele determinados as concentrações de ART e etanol, de acordo com item 4.3 e 4.6, e o material sedimentado foi utilizado para fermentação posterior.

\subsubsection{Método para determinação da massa seca}

Foram transferidas com uma pipeta, $10 \mathrm{~g}$ de amostra de vinho proveniente do Erlenmayer de propagação, para tubos de centrífuga e pesadas em balança com quatro dígitos decimais. Centrifugou-se a amostra por cinco minutos à $4000 \mathrm{~g}$. 
O sobrenadante foi descartado e o material sedimentado foi ressuspenso em água destilada e centrifugado novamente por cinco minutos à $4000 \mathrm{~g}$. Esta operação repetiu-se por três vezes.

Após a última centrifugação, descartou-se o sobrenadante, ressuspendeuse o sedimentado com o mínimo possível de água destilada e este foi transferido para uma placa de Petri $(100 \times 20 \mathrm{~mm})$, previamente seca e tarada.

Lavou-se bem o tubo de centrífuga com água destilada, para certificar-se que toda a massa contida neste foi transferida para a placa de Petri, a qual foi levada à estufa sem circulação de ar, por 24 horas à $80^{\circ} \mathrm{C}$. Após retirá-la da estufa, deixou-se esfriar em dessecador até peso constante e pesou-se em balança analítica.

$$
\begin{aligned}
& \text { Cálculo: } \quad \mathrm{MS}=(\mathrm{PA}-\mathrm{PV}) / 10 \\
& \text { onde : } \quad \text { MS = massa seca } \mathrm{em} \mathrm{g} / \mathrm{g} \text { de material fermentado } \\
& \text { PA = peso da placa mais amostra seca } \\
& \mathrm{PV}=\text { peso da placa }(\text { tara })
\end{aligned}
$$

Foram realizadas duas repetições para cada tratamento.

\subsubsection{Fermentação}

As fermentações foram realizadas em frascos de Erlenmayer de $500 \mathrm{ml}$, à temperatura de $35 \pm 1^{\circ} \mathrm{C}$, conduzidas em "shaker". Para Erlenmayer previamente pesado (EFV - para a determinação da massa inicial de meio e massa final de material fermentado), foram transferidos $100 \mathrm{ml}$ de meio 3. Após esterilização e resfriamento até temperatura ambiente, este Erlenmayer foi novamente pesado (EFM - determinação da quantidade de açúcar inicial). Um Erlenmayer extra, nas mesmas condições, foi preparado e esterilizado, e após resfriado, seu conteúdo foi coletado e deste determinado a concentração de ART.

A massa celular obtida na propagação (item 4.7.1) após ressuspensão com parte do mosto de fermentação, foi totalmente transferida para o Erlenmayer de fermentação, o qual foi novamente pesado para se determinar a massa de inóculo (EFI). 
Após a inoculação, o Erlenmayer foi incubado em "shaker" a $35 \pm 1{ }^{\circ} \mathrm{C} / 24$ h. Ao final deste tempo, o Erlenmayer foi pesado (EFF - para determinação do peso final do material fermentado). Foram retiradas 2 amostras de $10 \mathrm{~g}$ cada para a determinação de massa seca (conforme item 4.7.1.1). O restante do material foi centrifugado e o sobrenadante coletado para análise de ART e de etanol e o precipitado descartado.

Ao final de cada ensaio de propagação e fermentação foram coletadas amostras para as seguintes determinações:

- $\mathrm{pH}$

- Concentração de Açúcares Redutores Totais

- Concentração de Etanol

- Concentração da Massa Celular

O procedimento para determinação dos rendimentos em etanol e biomassa encontra-se esquematizado na Figura 1.

\subsubsection{Determinação da massa de açúcar consumido na fermentação (MACF)}

A massa de açúcar consumida é dada por:

MASSA DE AÇÚCAR INICIAL - MASSA DE AÇÚCAR FINAL

Assim, a massa de açúcar consumido será calculado pela relação que se

segue:

$$
\text { MACF }=[(E F M-E F V) \times \text { ARTFI }]-[(E F F-E F V) \times \text { ARTFF }]
$$

onde:

MACF - Massa de açúcar consumido.

ARTFF - Concentração de açúcares redutores totais do Erlenmayer de fermentação após a incubação.

ARTFI - Concentração de açúcares redutores totais do meio 3.

EFF - Peso do Erlenmayer de fermentação após a incubação.

EFV - Peso do Erlenmayer de fermentação vazio.

EFM - Peso do Erlenmayer de fermentação após esterilização 


\subsubsection{Determinação da massa de etanol produzida na fermentação (MEPF)}

A massa de etanol produzida é dada por:

\section{MASSA DE ETANOL FINAL - MASSA DE ETANOL INICIAL}

Assim, a massa de etanol produzida será calculada pela relação que se segue:

$$
\mathrm{MEPF}=[(\mathrm{EFF}-\mathrm{EFV}) \times \mathrm{ETFF}]-[(\mathrm{EFI}-\mathrm{EFM}) \times 0,7 \times \mathrm{ETPF}]
$$

onde:

MEPF - Massa de etanol produzida.

ETFF - Concentração de etanol no Erlenmayer de fermentação após incubação.

ETPF - Concentração de etanol no Erlenmayer de propagação após incubação.

EFF - Peso do Erlenmayer de fermentação após a incubação.

EFV - Peso do Erlenmayer de fermentação vazio.

EFM - Peso do Erlenmayer de fermentação após esterilização.

EFI - Peso do Erlenmayer de fermentação após inoculação.

Para esta determinação, foi assumido que a concentração de etanol contido no líquido remanescente na massa celular precipitada na centrifugação do conteúdo do Erlenmayer de propagação é igual à do líquido sobrenadante. Assume-se que a biomassa úmida contem $70 \%$ de líquido. 


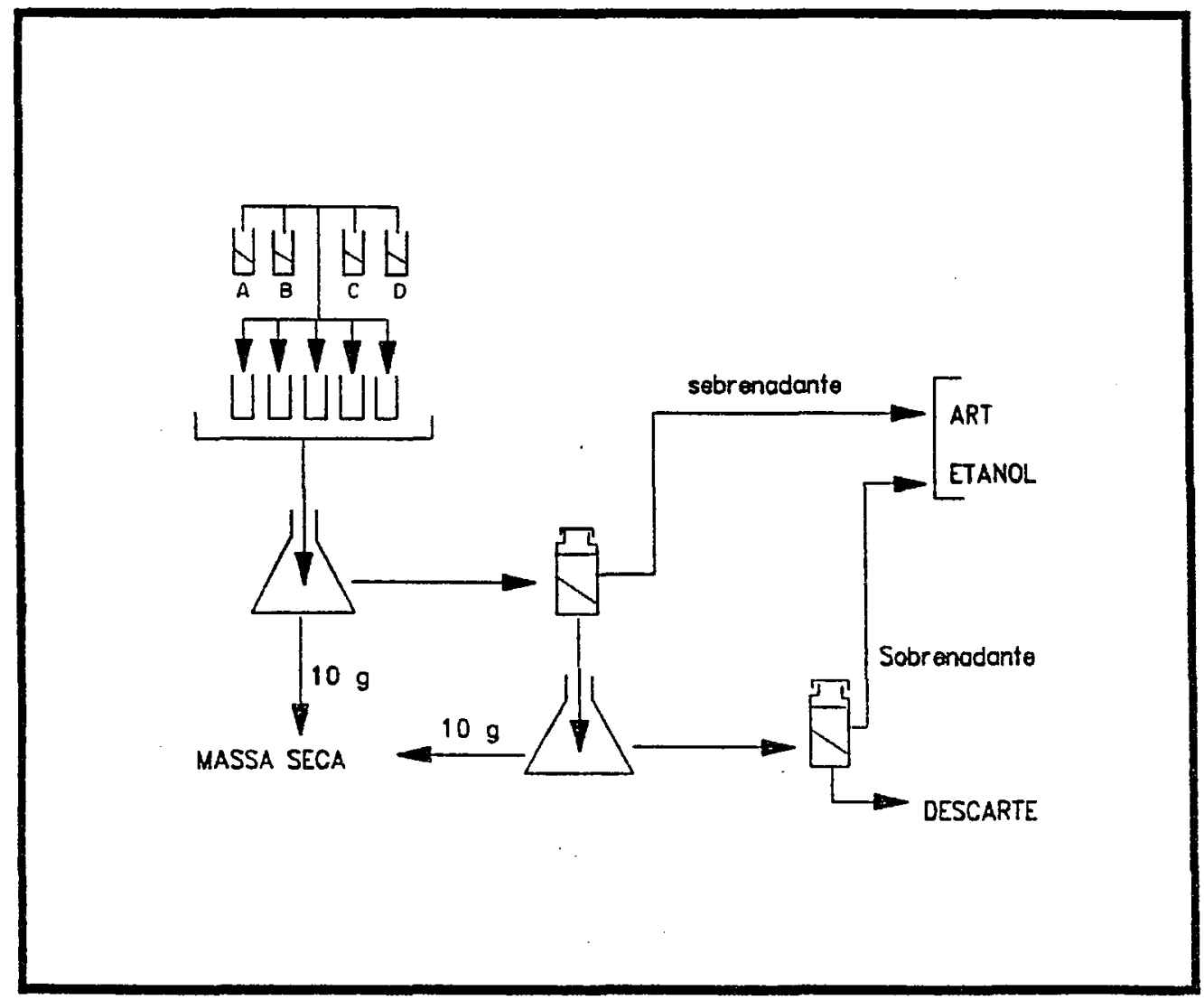

Figura 1. Esquema do procedimento experimental para determinação dos rendimentos em etanol e biomassa. 


\subsubsection{Determinação da massa celular produzida na fermentação (MCPF)}

A massa celular produzida é dada pela seguinte relação:

MASSA CELULAR FINAL - MASSA CELULAR INICIAL

$\mathrm{MCPF}=[(\mathrm{EFF}-\mathrm{EFV}) \times \mathrm{MSFF}]-[(\mathrm{EPF}-\mathrm{EPV}) \times \mathrm{MSPF} / 10]$

onde:

MCPF - Massa celular produzida.

MSFF - Concentração celular (massa seca) no Erlenmayer de fermentação após incubação.

MSPF - Concentração celular (massa seca) no Erlenmayer de propagação após incubação.

EFF - Peso do Erlenmayer de fermentação após a incubação.

EPV - Peso do Erlenmayer de propagação vazio.

EPF - Peso do Erlenmayer de propagação após a incubação.

4.7.6 Determinação do rendimento em etanol $\left(Y_{p / s}\right)$

$$
\mathrm{Y}_{\mathrm{p} / \mathrm{s}}=\frac{\text { MEPF }}{-------}
$$

onde: MEPF - Massa de Etanol Produzida na Fermentação

AIM3 - Açúcar Inicial Meio 3

\subsubsection{Determinação do rendimento em massa celular} $\left(Y_{x / s}\right)$

MCPF

$$
\mathbf{Y}_{\mathrm{X} / \mathrm{s}}=\mathbf{- - - - - - -}
$$

onde: MCPF - Massa Celular Produzida na Fermentação ACFMC - Açúcar Consumido para Formação de Massa Celular 


\subsection{Determinação da velocidade específica de crescimento máxima $\left(\mu_{\max }\right)$}

A determinação da velocidade específica de crescimento máxima $\left(\mu_{\max }\right)$ pode ser um instrumento importante no reconhecimento das leveduras instaladas no processo, uma vez que é específica para cada microrganismo (RODRIGUES, 1989). Segundo este mesmo autor, o aumento da população microbiana está relacionado com a quantidade populacional e uma constante de proporcionalidade $\mu$ (velocidade específica de crescimento), ou seja:

$$
\stackrel{d X}{---}=\mu X
$$

onde:

$\mu$ - velocidade específica de crescimento

$\mathrm{t}$ - tempo

$\mathrm{dX} / \mathrm{dt}$ - velocidade de produção de massa celular que integrada fornece:

$$
\begin{gathered}
X \\
\ln ---=\mu t \\
X_{0}
\end{gathered}
$$

onde:

$X$ - Concentração de células no tempo $t$

$\mathrm{X}_{0}$ - Concentração de células no tempo 0

$\boldsymbol{\mu}$ - Velocidade específica de crescimento

t - Tempo

Conforme Figura 2, observa-se um gráfico de $\ln \left(X / X_{0}\right)$ versus $t$ onde, obtém-se uma curva e o valor de $\mu_{\max }$ (velocidade específica de crescimento máxima) é dado pela inclinação da fase linear da curva. 


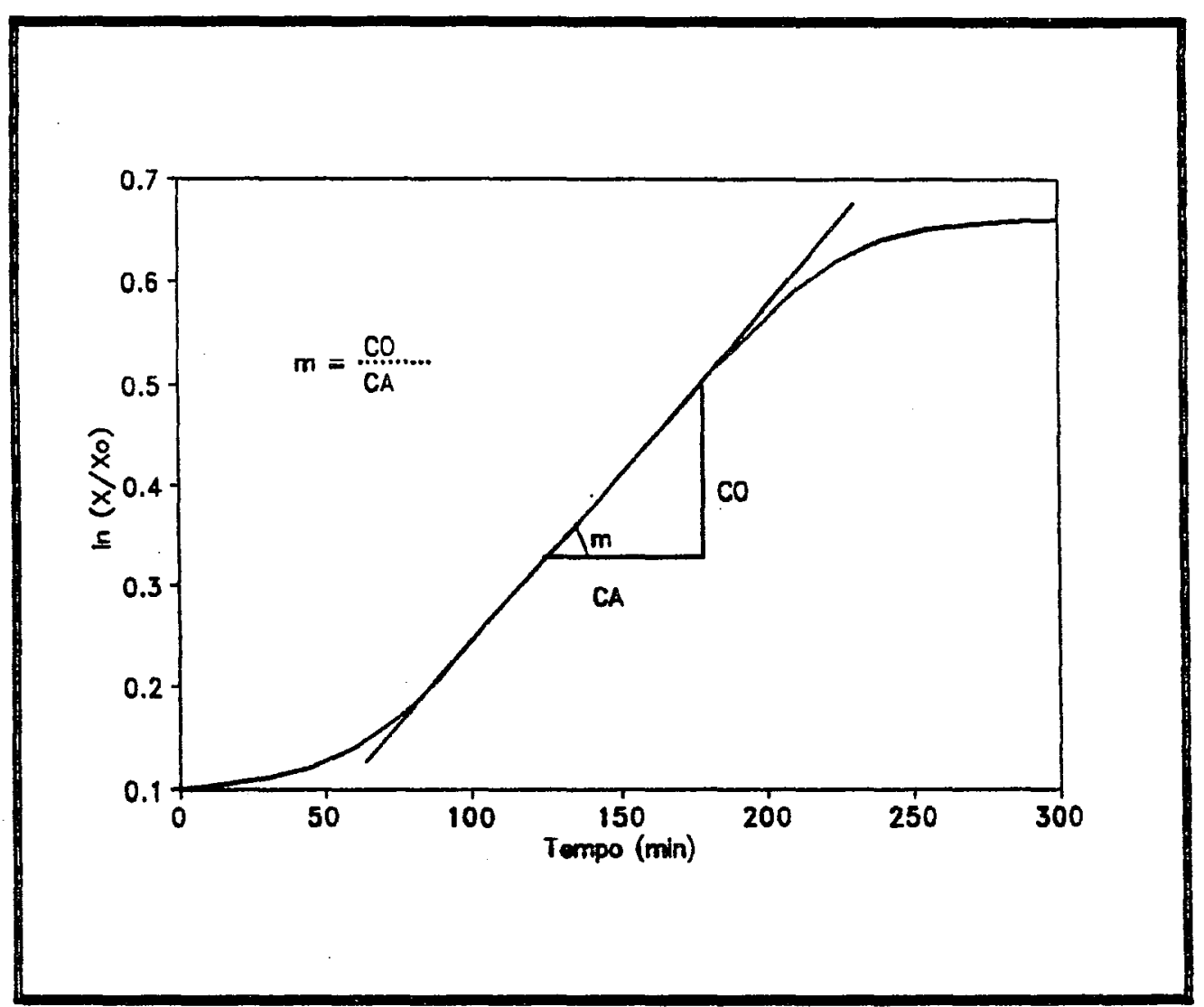

Figura 2. Curva de crescimento microbiano, onde a inclinação da parte linear (m) é o valor de $\mu_{\text {máx }}$ (RODRIGUES, 1989). 
A determinação desta constante foi realizada segundo RODRIGUES (1989):

Foram utilizados $300 \mathrm{ml}$ de meio 2 em Erlenmayer de $1000 \mathrm{ml}$, o qual recebeu dois dos tubos descritos em 4.8.1. Este foi incubado a $35 \pm 1^{\circ} \mathrm{C}$ em "shaker" . A partir da inoculação amostras de $2 \mathrm{ml}$ foram retiradas no tempo 0 , e a partir disto em intervalos de 15 minutos até a quinta hora.

A leitura de absorbância foi feita em espectrofotômetro a $620 \mathrm{~nm}$ contra um branco constituído de água destilada. A concentração celular foi calculada segundo uma curva de calibração previamente estabelecida (APÊNDICE 1). Com esses dados foi construída a curva de ln da densidade ótica (D.O.) versus tempo, onde o $\mu_{\max }$ foi obtido na fase linear da curva de crescimento, determinando-se sua inclinação $(\operatorname{tg} \alpha)$.

O esquema completo encontra-se na Figura 3.

\subsubsection{Curva de calibração utilizada nos ensaios para determinação da massa seca}

Centrifugou-se $75 \mathrm{ml}$ de meio de cultura conforme item 4.9 , à $4000 \mathrm{~g}$ por 15 minutos. Com o material precipitado fez-se a ressuspensão com água destilada e diluições em balões volumétricos. Com esta diluição, fez-se a determinação de massa seca por filtração em membrana Millipore $0,22 \mu(\emptyset=47 \mathrm{~mm})$ e posterior secagem em estufa à $105^{\circ} \mathrm{C}$ até peso constante. $\mathrm{E}$ também, com este material foi feita a leitura de absorbância à $620 \mathrm{~nm}$ de todas as diluições e relacionou-se com a concentração celular obtida por massa seca. Este método foi realizado para cada tratamento e obteve-se assim uma curva de calibração utilizada para cada tratamento. (APÊNDICE 1) 


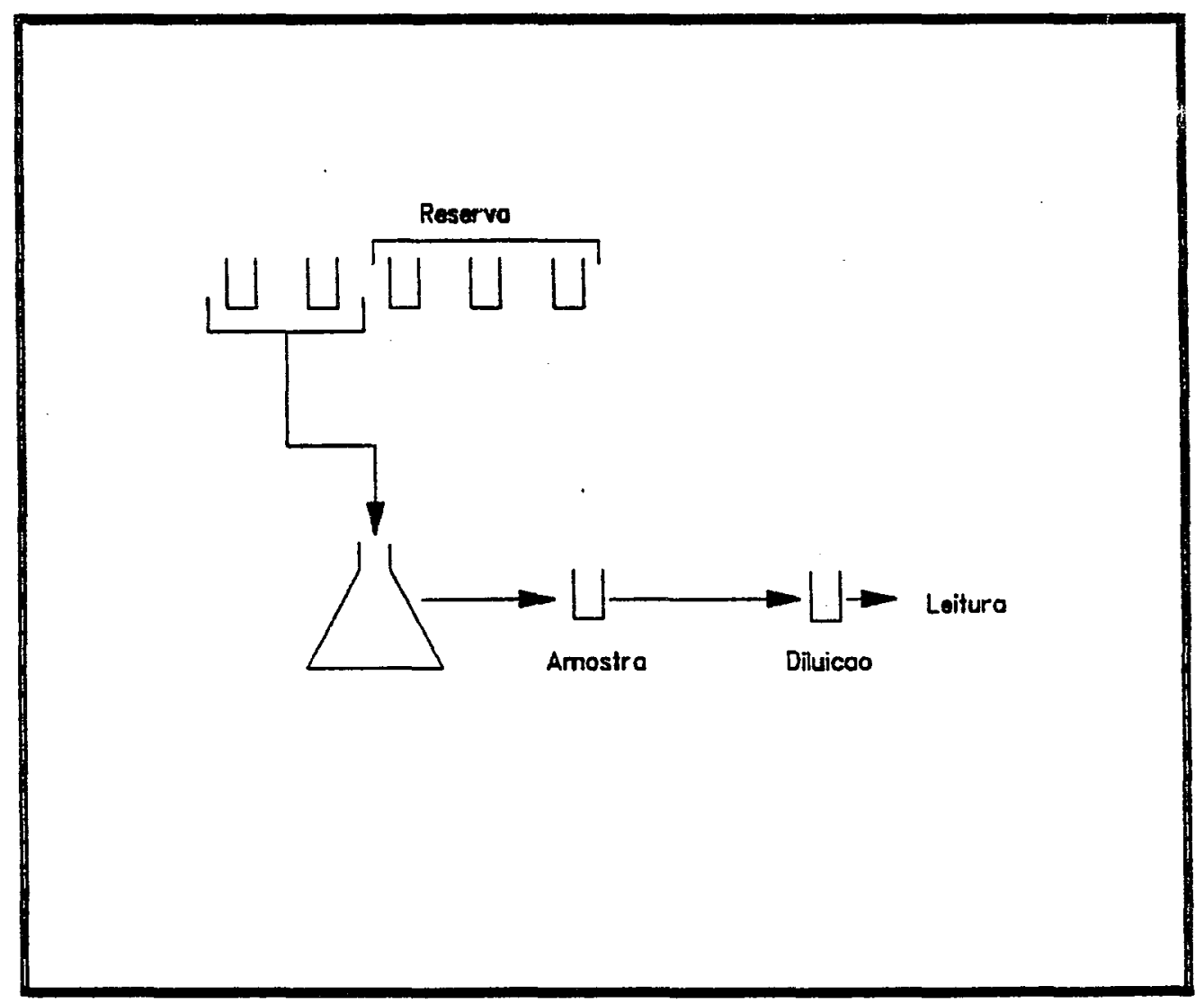

Figura 3. Esquema do procedimento experimental para determinação de $\mu_{\text {máx. }}$ 


\subsection{Delineamento Experimental e Análise Estatística}

A análise estatística dos dados obtidos foi realizada segundo o modelo matemático para o delineamento em blocos incompletos descrito por COCHRAN \& COX (1957). Um total de 15 tratamentos foram desenvolvidos como descritos a seguir:
A = Candida krusei
$\mathrm{B}=$ Saccharomyces cerevisiae (fermento prensado Fleischmann)
$\mathrm{C}=$ Saccharomyces cerevisiae (M-300-A)
$\mathrm{D}=$ Saccharomyces uvarum IZ-1904

TRATAMENTOS LEVEDURAS

$\begin{array}{rr}1 & \text { A } \\ 2 & \text { B } \\ 3 & \text { C } \\ 4 & \text { D } \\ 5 & \text { AB } \\ 6 & \text { AC } \\ 7 & \text { AD } \\ 8 & \text { BC } \\ 9 & \text { BD } \\ 10 & \text { CD } \\ 11 & \text { ABC } \\ 12 & \text { ABD } \\ 13 & \text { BCD } \\ 14 & \text { ACD } \\ 15 & \text { ABCD }\end{array}$

A análise dos dados foi realizada com o auxílio do programa Statistical Analysis System - SAS. 


\section{RESULTADOS E DISCUSSÃo}

\subsection{Fermentação}

A fim de avaliar as características importantes para a fermentação como produção e rendimento em etanol e biomassa, para as leveduras $S$. cerevisiae (Fleischmann), S. cerevisiae (TA), S. uvarum IZ-1904 e Candida krusei, em cultura pura e mista, foram conduzidos um total de 15 tratamentos com 8 repetições cada, os quais estão sumarizados na tabela 1. Os dados originais encontram-se no APÊNDICE 2.

Tabela 1. Valores médios* dos ensaios de fermentação: massa celular (g), massa de etanol $(\mathrm{g})$, rendimento celular $(\mathrm{g} / \mathrm{g})$, rendimento em etanol $(\mathrm{g} / \mathrm{g}), \mathrm{pH}$ final, viabilidade celular (\%), ART meio 3 (\%), açúcar consumido (\%).

\begin{tabular}{|c|l|l|l|l|l|l|l|l|}
\hline $\begin{array}{l}\text { Trata- } \\
\text { mento }\end{array}$ & $\begin{array}{l}\text { Massa } \\
\text { celular }\end{array}$ & $\begin{array}{l}\text { Massa de } \\
\text { etanol }\end{array}$ & $\begin{array}{l}\text { Rend. } \\
\text { celular }\end{array}$ & $\begin{array}{l}\text { Rend. } \\
\text { etanol }\end{array}$ & $\begin{array}{l}\text { pH } \\
\text { final }\end{array}$ & $\begin{array}{l}\text { Viab. } \\
\text { celular }\end{array}$ & $\begin{array}{l}\text { ART meio } \\
3\end{array}$ & $\begin{array}{l}\text { Açúcar } \\
\text { consumido }\end{array}$ \\
\hline 1 & 0.6394 & 3.033 & 0.2894 & 0.2231 & 4.87 & 98.90 & 13.6702 & 8.5191 \\
2 & 0.8377 & 4.689 & 0.2119 & 0.3389 & 3.86 & 98.51 & 13.9062 & 13.5832 \\
3 & 0.9029 & 4.759 & 0.2486 & 0.3425 & 3.94 & 98.01 & 13.9371 & 13.5444 \\
4 & 0.7065 & 4.810 & 0.1745 & 0.3464 & 3.83 & 98.38 & 13.9125 & 13.6051 \\
5 & 0.8204 & 4.802 & 0.2367 & 0.3548 & 3.99 & 98.15 & 13.5644 & 13.2341 \\
6 & 0.8197 & 4.655 & 0.2097 & 0.3433 & 4.00 & 98.16 & 13.6218 & 13.2586 \\
7 & 0.6641 & 4.742 & 0.1657 & 0.3434 & 4.23 & 98.69 & 13.8177 & 13.3509 \\
8 & 0.8303 & 4.733 & 0.2357 & 0.3499 & 3.88 & 97.34 & 13.5799 & 13.2200 \\
9 & 0.8674 & 4.790 & 0.2130 & 0.3464 & 3.82 & 98.27 & 13.8379 & 13.4903 \\
10 & 0.8832 & 4.587 & 0.2129 & 0.3374 & 3.82 & 98.45 & 13.6152 & 13.2348 \\
11 & 0.8284 & 4.687 & 0.2206 & 0.3479 & 3.98 & 97.61 & 13.5077 & 13.1538 \\
12 & 0.7926 & 4.751 & 0.2092 & 0.3502 & 3.99 & 97.70 & 13.5774 & 13.2092 \\
13 & 0.8518 & 4.733 & 0.2226 & 0.3492 & 3.81 & 97.71 & 13.5843 & 13.2391 \\
14 & 0.8073 & 4.728 & 0.2112 & 0.3477 & 4.03 & 97.93 & 13.6426 & 13.2765 \\
15 & 0.8492 & 4.889 & 0.2081 & 0.3484 & 3.96 & 98.23 & 14.0424 & 13.7141 \\
\hline
\end{tabular}

* Os valores apresentados são médias de 8 repetições.

\subsection{Análise Estatística}

Através da tabela 2, observa-se que o tratamento 1 compreendido pela levedura Candida krusei, foi o que menos consumiu açúcar quando comparado com os 
demais tratamentos e de acordo com a análise da variância (Tabela 3), houve diferença significativa ao nível de $1 \%$ para os tratamentos. Nota-se ainda um grupo de tratamentos ( 5 ao 14) com associação de 2 e 3 linhagens de leveduras, sendo:

- tratamento 5: C. krusei e Fleischmann

- tratamento 6: C. krusei e M-300-A

- tratamento 7: C. krusei e $S$. uvarum

- tratamento 8: Fleischmann e M-300-A

- tratamento 9: Fleischmann e $S$. uvarum

- tratamento 10: M-300-A e S. uvarum

- tratamento 11: C. krusei, Fleischmann e M-300-A

- tratamento 12: C. krusei, Fleischmann e S. uvarum

- tratamento 13: Fleischmann, M-300-A e $S$. uvarum

- tratamento 14: C. krusei, M-300-A e S. uvarum

que não diferem significativamente entre si. A massa de açúcar consumida na fermentação foi maior para o tratamento 15 onde estão presentes as quatro leveduras.

Tabela 2. Teste Tukey para médias dos valores do consumo de açúcar durante os ensaios de fermentação (\%).

\begin{tabular}{|c|c|c|c|c|}
\hline Tratamento & Média & Repetição & \multicolumn{2}{|c|}{ Teste Tukey } \\
\hline 15 & 13.7141 & 8 & $a$ & \\
\hline 4 & 13.6051 & 8 & b & \\
\hline 2 & 13.5832 & 8 & $\mathrm{~b}$ & c \\
\hline$\overline{3}$ & 13.5444 & 8 & b & c \\
\hline 9 & 13.4903 & 8 & $\mathrm{~b}$ & c \\
\hline 7 & 13.3509 & 8 & $\mathbf{a}$ & c d \\
\hline 14 & 13.2765 & 8 & b & c d \\
\hline 6 & 13.2586 & 8 & b & c d \\
\hline 13 & 13.2391 & 8 & $\mathrm{~b}$ & c d \\
\hline 10 & 13.2348 & 8 & b & c d \\
\hline 5 & 13.2341 & 8 & b & c d \\
\hline 8 & 13.2200 & 8 & b & c d \\
\hline 12 & 13.2092 & 8 & & c d \\
\hline 11 & 13.1538 & 8 & & $\mathrm{~d}$ \\
\hline 1 & 8.5191 & 8 & & $\mathrm{e}$ \\
\hline
\end{tabular}

Médias seguidas por letras distintas diferem entre si ao nível de $5 \%$ de significância. 
Tabela 3: Análise da Variância dos valores médios do consumo de açúcar

\begin{tabular}{|l|c|c|c|c|l|}
\hline $\begin{array}{l}\text { Causa de } \\
\text { Variação }\end{array}$ & $\begin{array}{l}\text { Graus de } \\
\text { Liberdade }\end{array}$ & $\begin{array}{l}\text { Soma dos } \\
\text { Quadrados }\end{array}$ & $\begin{array}{l}\text { Quadrado } \\
\text { Médio }\end{array}$ & Valor F & Prob.>F \\
\hline Modelo & 28 & 234.451 & 8.373 & 167.62 & 0.0001 \\
Resíduo & 91 & 4.546 & 0.049 & & \\
Total & 119 & 238.997 & & & \\
Bloco & 14 & 55.615 & 3.972 & 79.52 & 0.0001 \\
Tratamento & 14 & 158.263 & 11.304 & 226.30 & 0.0001 \\
\hline
\end{tabular}

Coeficiente de variação: $1,71 \%$

Observando-se o quadro que compara as médias pelo teste de Tukey (tabela 4), pode-se constatar que a levedura Candida krusei (tratamento 1), apresentou menor formação de massa de etanol e a presença desta levedura em associação com outras, não afetou significativamente os demais tratamentos. A maior formação de massa de etanol ocorreu no tratamento 15 onde estão presentes as quatro leveduras. Comparando as leveduras $S$. uvarum e $S$. cerevisiae $\mathrm{M}-300-\mathrm{A}$, observa-se uma maior formação de massa de etanol pela levedura $S$. uvarum, seguida da M-300-A, o que codiz com a literatura (GUTIERREZ, 1994). Este autor relacionou a baixa viabilidade celular com uma maior formação de etanol pela levedura $S$. uvarum, e devido a todos os tratamentos não apresentarem diferença significativa quanto a viabilidade, conforme Tabela 1, não foi possível identificar esta mesma relação.

Tabela 4. Teste Tukey para médias dos valores da formação de massa de etanol (g)

\begin{tabular}{|c|c|c|c|}
\hline Tratamento & Média & Repetição & Teste Tukey \\
\hline 15 & 4.889 & 8 & $\mathrm{a}$ \\
4 & 4.810 & 8 & $\mathrm{a}$ \\
5 & 4.802 & 8 & $\mathrm{a}$ \\
9 & 4.790 & 8 & $\mathrm{a}$ \\
3 & 4.759 & 8 & $\mathrm{a}$ \\
12 & 4.751 & 8 & $\mathrm{a}$ \\
7 & 4.742 & 8 & $\mathrm{a}$ \\
8 & 4.733 & 8 & $\mathrm{a}$ \\
13 & 4.733 & 8 & $\mathrm{a}$ \\
14 & 4.728 & 8 & $\mathrm{a}$ \\
2 & 4.689 & 8 & $\mathrm{a}$ \\
11 & 4.687 & 8 & $\mathrm{a}$ \\
6 & 4.655 & 8 & $\mathrm{a}$ \\
10 & 4.587 & 8 & $\mathrm{~b}$ \\
1 & 3.033 & 8 & $\mathrm{~g}$ \\
\hline
\end{tabular}

Médias seguidas por letras distintas diferem entre si ao nível de $5 \%$ de significância. 
Tabela 5: Análise da Variância dos valores médios da formação de massa de etanol

\begin{tabular}{|c|c|c|c|c|c|}
\hline $\begin{array}{ll}\text { Causa } & \text { de } \\
\text { Variação } & \end{array}$ & $\begin{array}{l}\text { Graus de } \\
\text { Liberdade }\end{array}$ & $\begin{array}{l}\text { Soma dos } \\
\text { Quadrados }\end{array}$ & $\begin{array}{l}\text { Quadrado } \\
\text { Médio }\end{array}$ & Valor F & Prob. $>\mathrm{F}$ \\
\hline Modelo & 28 & 24.694 & 0.882 & 10.13 & 0.0001 \\
\hline Resíduo & 91 & 7.920 & 0.087 & & \\
\hline Total & 119 & 32.614 & & & \\
\hline Bloco & 14 & 2.383 & 0.170 & 1.96 & 0.0303 \\
\hline Tratamento & 14 & 22.014 & 1.572 & 18.07 & 0.0001 \\
\hline
\end{tabular}

Coeficiente de variação: $6,38 \%$

Com relação à formação de massa celular (tabela 6), nota-se que o tratamento 3 (M-300-A), obteve o maior valor, porém, através da análise da variância, observa-se que os tratamentos 1, 4, e 7 compreendidos pelas leveduras Candida krusei, Saccharomyces uvarum e Candida krusei + Saccharomyces uvarum, respectivamente, diferem dos demais, indicando que a cultura pura das leveduras Candida krusei e S. uvarum possuem o mesmo desempenho da cultura mista destas mesmas leveduras.

Tabela 6. Teste Tukey para médias dos valores da formação de massa celular (g).

\begin{tabular}{|c|c|c|c|c|}
\hline Tratamento & Média & Repetição & \multicolumn{2}{|c|}{ Teste Tukey } \\
\hline 3 & 0.9029 & 8 & $a$ & \\
\hline 10 & 0.8831 & 8 & a & \\
\hline 9 & 0.8674 & 8 & a & \\
\hline 13 & 0.8518 & 8 & a & \\
\hline 15 & 0.8492 & 8 & a & \\
\hline 2 & 0.8377 & 8 & a & \\
\hline 8 & 0.8303 & 8 & $\mathbf{a}$ & \\
\hline 11 & 0.8284 & 8 & $\mathbf{a}$ & \\
\hline 5 & 0.8204 & 8 & a & \\
\hline 6 & 0.8197 & 8 & a & \\
\hline 14 & 0.8073 & 8 & $\mathbf{a}$ & \\
\hline 12 & 0.7926 & 8 & $\mathbf{a}$ & \\
\hline 4 & 0.7065 & 8 & $b$ & c \\
\hline 7 & 0.6641 & 8 & & $\mathrm{c}$ \\
\hline 1 & 0.6394 & 8 & & c \\
\hline
\end{tabular}

Médias seguidas por letras distintas diferem entre si ao nível de $5 \%$ de significância. 
Tabela 7: Análise da Variância dos valores médios da formação de massa celular

\begin{tabular}{|l|c|c|c|c|l|}
\hline $\begin{array}{l}\text { Causa de } \\
\text { Variação }\end{array}$ & $\begin{array}{l}\text { Graus de } \\
\text { Liberdade }\end{array}$ & $\begin{array}{l}\text { Soma dos } \\
\text { Quadrados }\end{array}$ & $\begin{array}{l}\text { Quadrado } \\
\text { Médio }\end{array}$ & Valor F & Prob.>F \\
\hline Modelo & 28 & 1.547 & 0.055 & 12.76 & 0.0001 \\
Resíduo & 91 & 0.394 & 0.004 & & \\
Total & 119 & 1.941 & & & \\
Bloco & 14 & 0.879 & 0.063 & 14.49 & 0.0001 \\
Tratamento & 14 & 0.487 & 0.035 & 8.04 & 0.0001 \\
\hline
\end{tabular}

Coeficiente de variação: $8,16 \%$

Pode ser visto na Tabela 8, que quanto ao rendimento em etanol, a presença da levedura Candida krusei não afetou significativamente a atividade de outras leveduras, como tem ocorrido em condições industriais. Isto pode ser explicado pelo fato de que estes ensaios foram realizados com apenas um ciclo de fermentação, e portanto, a levedura Candida krusei não aumentou sua massa celular o suficiente para interferir no rendimento em etanol das outras culturas.

Tabela 8. Teste Tukey para médias dos valores do rendimento em etanol $(\mathrm{g} / \mathrm{g})$.

\begin{tabular}{|c|c|c|c|}
\hline Tratamento & Médias & Repetição & Teste Tukey \\
\hline 5 & 0.3548 & 8 & $a$ \\
\hline 12 & 0.3502 & 8 & a \\
\hline 8 & 0.3499 & 8 & a \\
\hline 13 & 0.3492 & 8 & a \\
\hline 15 & 0.3484 & 8 & a \\
\hline 11 & 0.3479 & 8 & $\mathrm{a}$ \\
\hline 14 & 0.3477 & 8 & $\mathrm{a}$ \\
\hline 9 & 0.3464 & 8 & a \\
\hline 4 & 0.3464 & 8 & a \\
\hline 7 & 0.3434 & 8 & $\mathbf{a}$ \\
\hline 6 & 0.3433 & 8 & a \\
\hline 3 & 0.3425 & 8 & a \\
\hline 2 & 0.3389 & 8 & $\mathbf{a}$ \\
\hline 10 & 0.3374 & 8 & a \\
\hline 1 & 0.2231 & 8 & b \\
\hline
\end{tabular}

Médias seguidas por letras distintas diferem entre si ao nível de 5\% de significância. 
Tabela 9: Análise da Variância dos valores médios do rendimento em etanol

\begin{tabular}{|l|c|c|c|c|l|}
\hline $\begin{array}{l}\text { Causa de de do } \\
\text { Variação }\end{array}$ & $\begin{array}{l}\text { Graus de } \\
\text { Liberdade }\end{array}$ & $\begin{array}{l}\text { Soma dos } \\
\text { Quadrados }\end{array}$ & $\begin{array}{l}\text { Quadrado } \\
\text { Médio }\end{array}$ & Valor F & Prob.>F \\
\hline Modelo & 28 & 0.1664 & 0.0059 & 12.65 & 0.0001 \\
Resíduo & 91 & 0.0428 & 0.0005 & & \\
Total & 119 & 0.2092 & & & \\
Bloco & 14 & 0.0511 & 0.0036 & 7.76 & 0.0001 \\
Tratamento & 14 & 0.1191 & 0.0085 & 18.10 & 0.0001 \\
\hline
\end{tabular}

Coeficiente de variação: $6,41 \%$

Por outro lado, quando linhagens foram cultivadas separadamente, a levedura Candida krusei apresentou maior rendimento celular (tabela 10), indicando que esta levedura em condições de fermentação utiliza a maior parte do açúcar para o crescimento celular e outros compostos.

Tabela 10.Teste Tukey para médias dos valores do rendimento celular $(\mathrm{g} / \mathrm{g})$.

\begin{tabular}{|c|c|c|cc|}
\hline Tratamento & Média & Repetição & Teste Tukey \\
\hline 1 & 0.2894 & 8 & a & \\
3 & 0.2486 & 8 & $\mathrm{a}$ & $\mathrm{b}$ \\
5 & 0.2367 & 8 & $\mathrm{a}$ & $\mathrm{b}$ \\
8 & 0.2357 & 8 & $\mathrm{a}$ & $\mathrm{b}$ \\
13 & 0.2226 & 8 & $\mathrm{a}$ & $\mathrm{b}$ \\
11 & 0.2206 & 8 & $\mathrm{a}$ & $\mathrm{b}$ \\
9 & 0.2130 & 8 & $\mathrm{a}$ & $\mathrm{b}$ \\
10 & 0.2129 & 8 & $\mathrm{a}$ & $\mathrm{b}$ \\
2 & 0.2119 & 8 & $\mathrm{a}$ & $\mathrm{b}$ \\
14 & 0.2112 & 8 & $\mathrm{a}$ & $\mathrm{b}$ \\
6 & 0.2097 & 8 & $\mathrm{a}$ & $\mathrm{b}$ \\
12 & 0.2092 & 8 & $\mathrm{a}$ & $\mathrm{b}$ \\
15 & 0.2081 & 8 & $\mathrm{a}$ & $\mathrm{b}$ \\
4 & 0.1745 & 8 & & $\mathrm{~b}$ \\
7 & 0.1657 & 8 & & $\mathrm{~b}$ \\
\hline
\end{tabular}

Médias seguidas por letras distintas diferem entre si ao nível de $5 \%$ de significância.

Tabela 11: Análise da Variância dos valores médios do rendimento celular.

\begin{tabular}{|l|c|c|c|c|l|}
\hline $\begin{array}{l}\text { Causa de } \\
\text { Variação }\end{array}$ & $\begin{array}{l}\text { Graus de } \\
\text { Liberdade }\end{array}$ & $\begin{array}{l}\text { Soma dos } \\
\text { Quadrados }\end{array}$ & $\begin{array}{l}\text { Quadrado } \\
\text { Médio }\end{array}$ & Valor F & Prob.>F \\
\hline Modelo & 28 & 0.4578 & 0.0164 & 6.25 & 0.0001 \\
Resíduo & 91 & 0.2379 & 0.0026 & & \\
Total & 119 & 0.6957 & & & \\
Bloco & 14 & 0.3639 & 0.0260 & 9.94 & 0.0001 \\
Tratamento & 14 & 0.0635 & 0.0045 & 1.73 & 0.0620 \\
\hline
\end{tabular}

Coeficiente de variação: $23,46 \%$ 


\subsection{Cinética de Crescimento Celular}

A tabela 12 apresenta $o$ valor de $\mu_{\text {máx }}$, que é bastante útil quando queremos comparar a velocidade de crescimento de várias linhagens, já que este parâmetro é uma característica própria de cada microrganismo. Os dados originais encontram-se no APÊNDICE 3.

A levedura $S$. cerevisiae (fermento Fleischmann prensado) apresentou o maior valor de $\mu_{\text {máx }}$ durante a propagação quando cultivada separadamente das demais, porém teve seu $\mu_{\text {máx }}$ reduzido consideravelmente quanto maior o número de leveduras associadas.

Ao contrário, a levedura $S$. uvarum obteve o menor valor de $\mu_{\text {máx }}$ quando cultivada separadamente das demais, e só apresentou seu valor reduzido quando associada com a levedura $S$. cerevisiae M-300-A.

A associação da levedura $C$. krusei com outras leveduras, resultou em $\mu_{\text {máx }}$ reduzido quando comparado com a cultura pura desta mesma levedura.

Observa-se também que os tratamentos com 2 leveduras associadas apresentam os valores de $\mu_{\text {máx }}$ reduzidos quando comparados com as culturas puras e valores mais baixos ainda apresentam os tratamentos com associação de 3 leveduras.

Com relação à fase lag, onde não ocorre crescimento celular, mas sim, uma adaptação do inóculo ao meio (COPERSUCAR, 1987; LEVEAU \& BOUIX, 1985; PELCZAR et al, 1980) pode ser observado que a levedura Saccharomyces uvarum apresenta uma fase lag mais demorada que as demais culturas. PAMMENT et al (1978) estudaram a fase lag da levedura Saccharomyces cerevisiae e encontraram uma relação inversa entre o tempo da fase lag e a quantidade de inóculo, sugerindo que a levedura precisa sintetizar níveis adequados de enzimas glicolíticas e respiratórias (PAMMENT \& HALL, 1978). Porém, com relação aos tratamentos, não houve diferença significativa na fase lag, pois o tempo de adaptação ao meio foi o mesmo para todos os tratamentos. 
Tabela 12. Velocidade específica de crescimento máxima ( $\left.\mu_{\operatorname{máx}}\right)$

\begin{tabular}{|c|c|c|}
\hline TRATAMENTO & $\boldsymbol{\mu}_{\mathbf{m a ́ x}}\left(\mathbf{h}^{-1}\right)$ & $\mathbf{r}$ \\
\hline 1 & 0.2018 & 0.999 \\
2 & 0.2535 & 0.992 \\
3 & 0.1706 & 0.992 \\
4 & 0.1442 & 0.996 \\
5 & 0.1925 & 0.993 \\
6 & 0.1593 & 0.993 \\
7 & 0.1654 & 0.996 \\
8 & 0.1468 & 0.993 \\
9 & 0.1634 & 0.998 \\
10 & 0.1477 & 0.994 \\
11 & 0.1355 & 0.997 \\
12 & 0.1321 & 0.997 \\
13 & 0.1141 & 0.985 \\
14 & 0.1362 & 0.984 \\
15 & 0.1576 & 0.995 \\
\hline
\end{tabular}




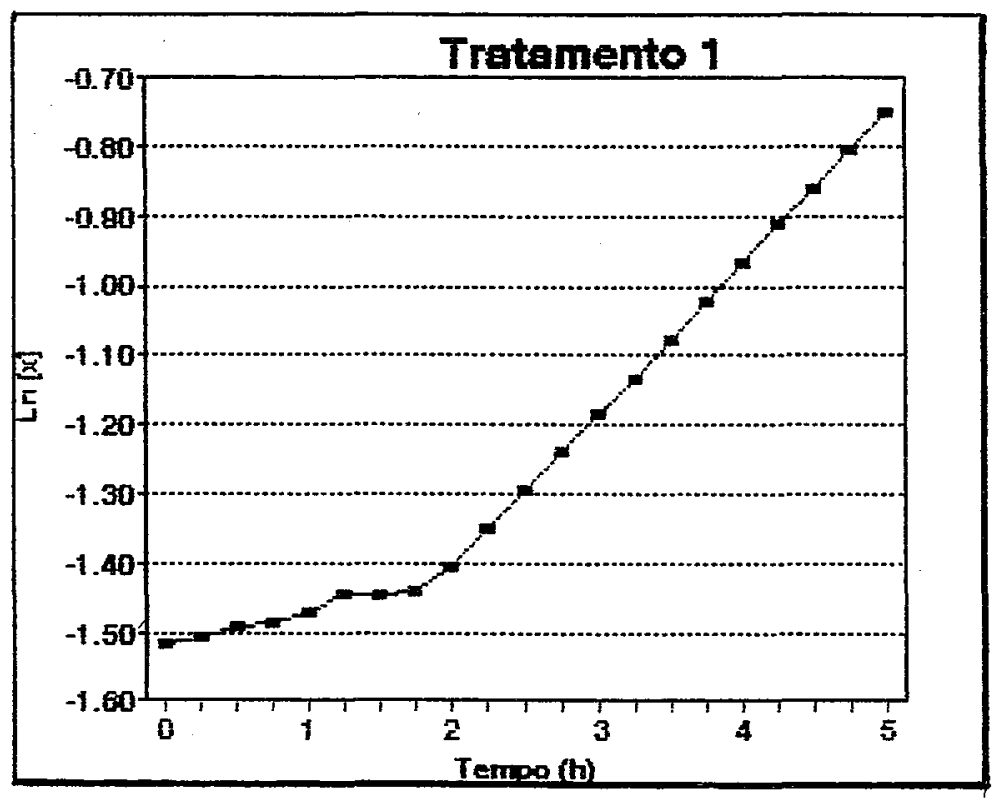

Figura 4. Curva de crescimento celular com $\mu_{\operatorname{máx}}=0,2018 \mathrm{~h}^{-1}$ Período de tempo do cálculo de $\mu_{\mathrm{max}}=2 \mathrm{~h} 00-4 \mathrm{~h} 45$

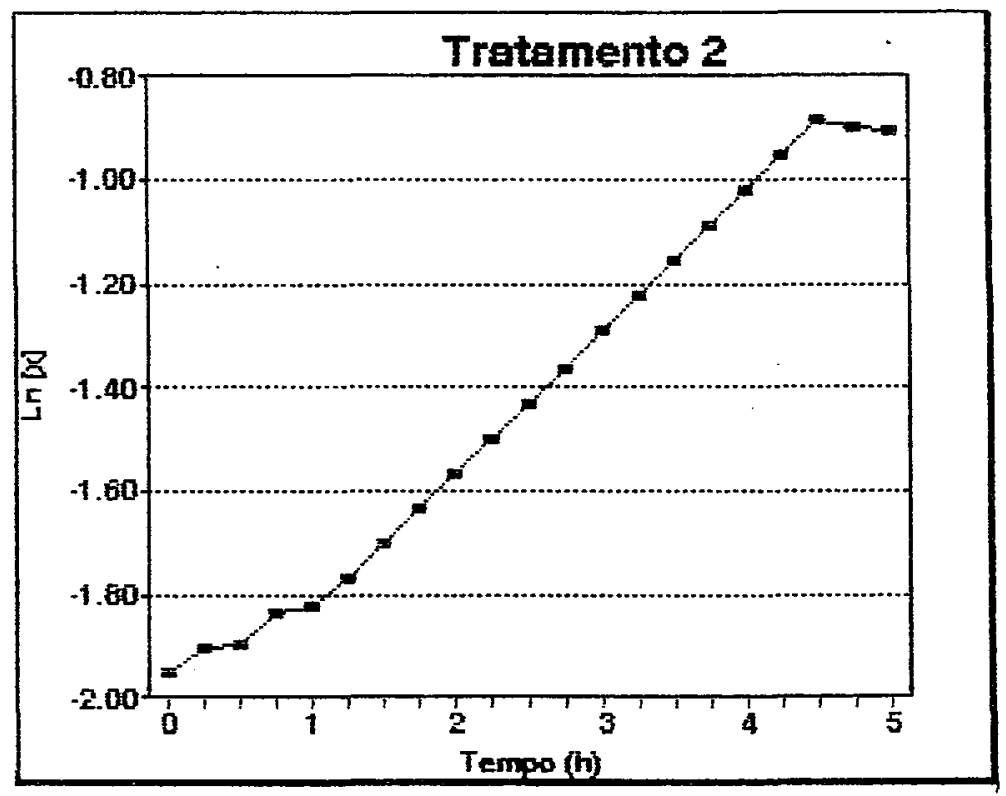

Figura 5. Curva de crescimento celular com $\mu_{\operatorname{máx}}=0,2535 \mathrm{~h}^{-1}$ Período de tempo do cálculo de $\mu_{\text {máx }}=1 \mathrm{~h} 15-4 \mathrm{~h} 30$ 


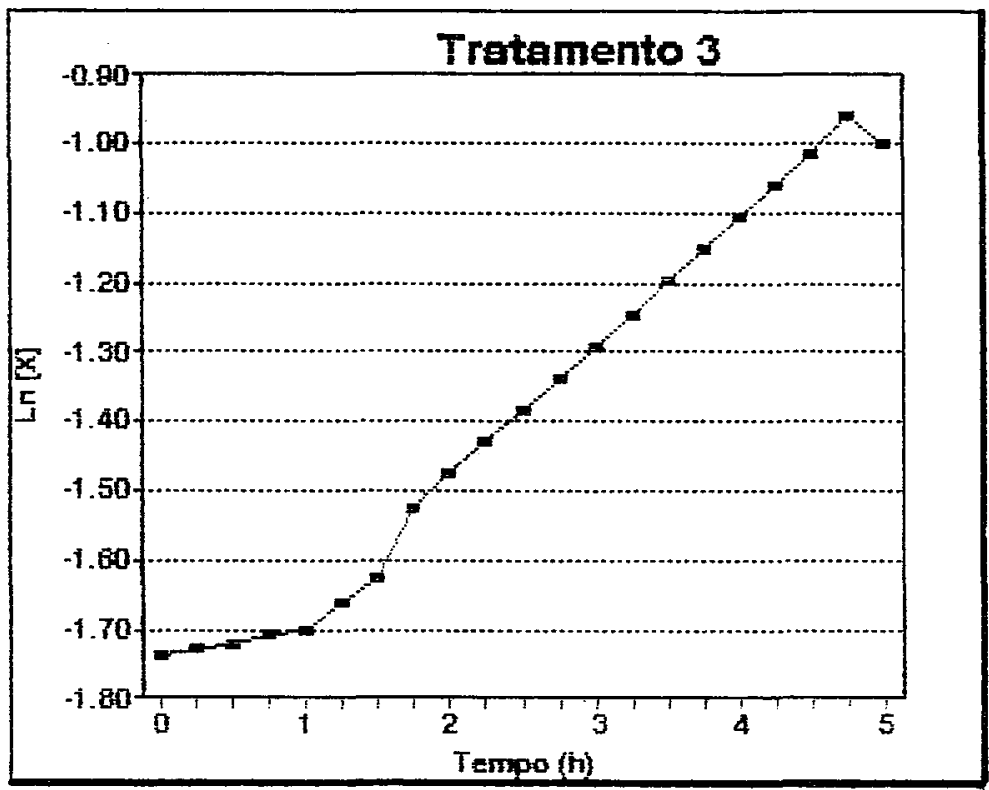

Figura 6. Curva de crescimento celular com $\mu_{\max }=0,1706 \mathrm{~h}^{-1}$ Período de tempo do cálculo de $\mu_{\text {máx }}=1 \mathrm{~h} 45-4 \mathrm{~h} 30$

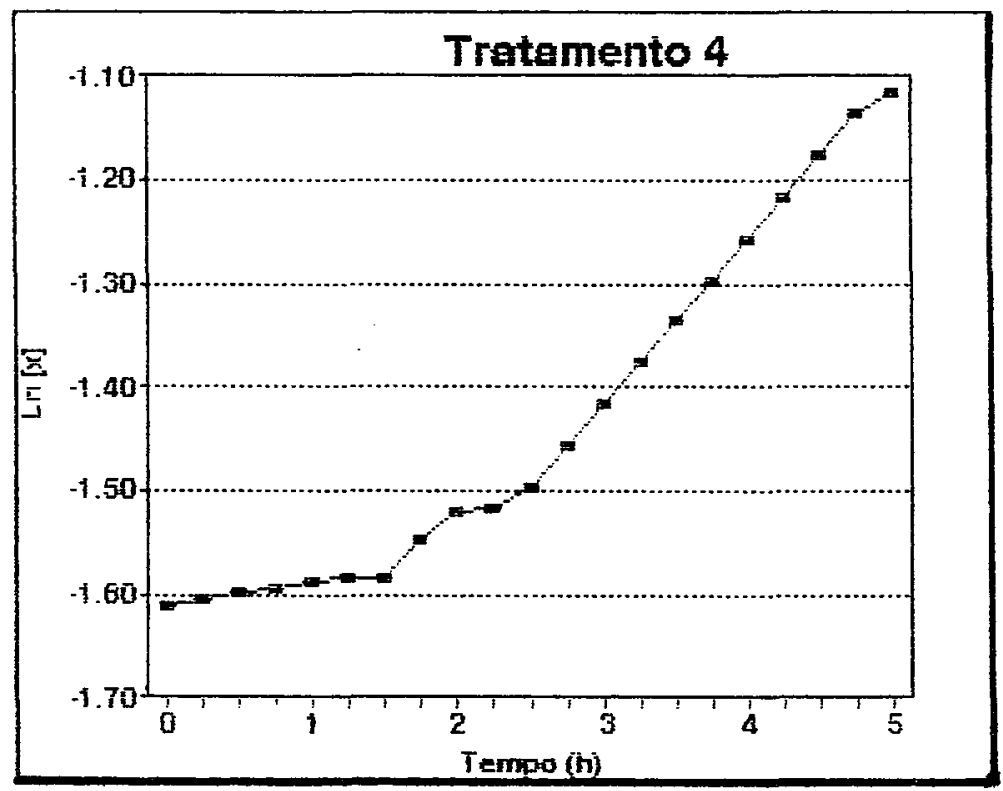

Figura 7. Curva de crescimento celular com $\mu_{\operatorname{máx}}=0,1442 \mathrm{~h}^{-1}$ Período de tempo do cálculo de $\mu_{\text {máx }}=2$ h30 - 4h45 


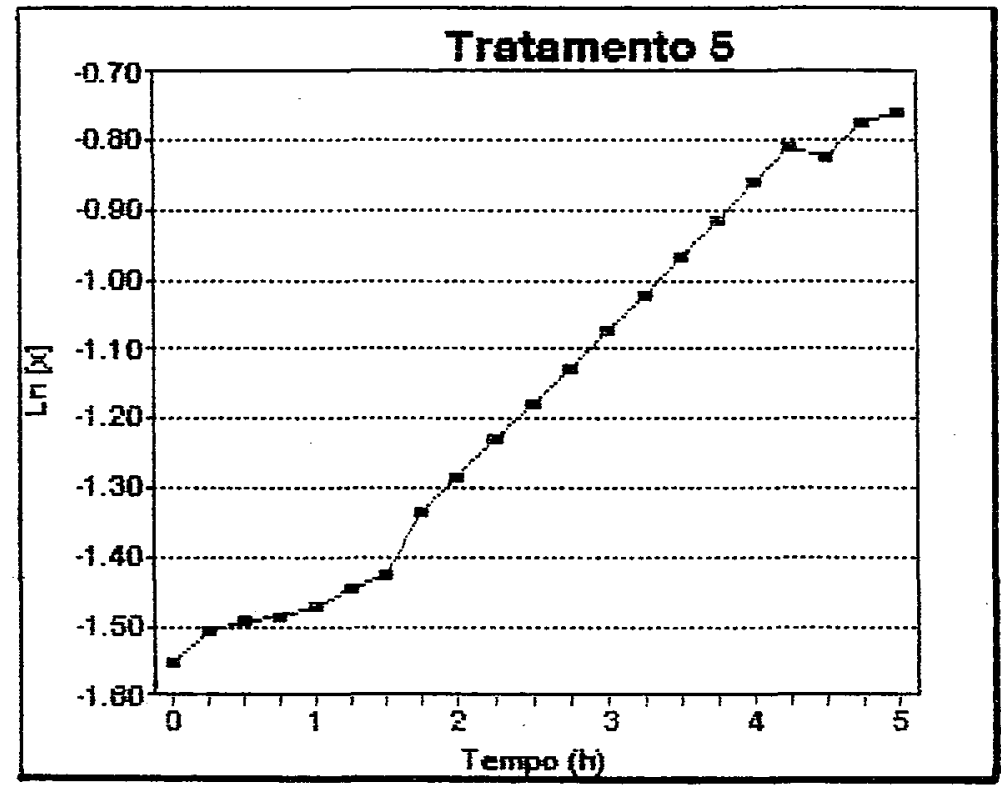

Figura 8. Curva de crescimento celular com $\mu_{\operatorname{máx}}=0,1925 \mathrm{~h}^{-1}$ Período de tempo do cálculo de $\mu_{\max }=1 \mathrm{~h} 45-4 \mathrm{~h} 15$

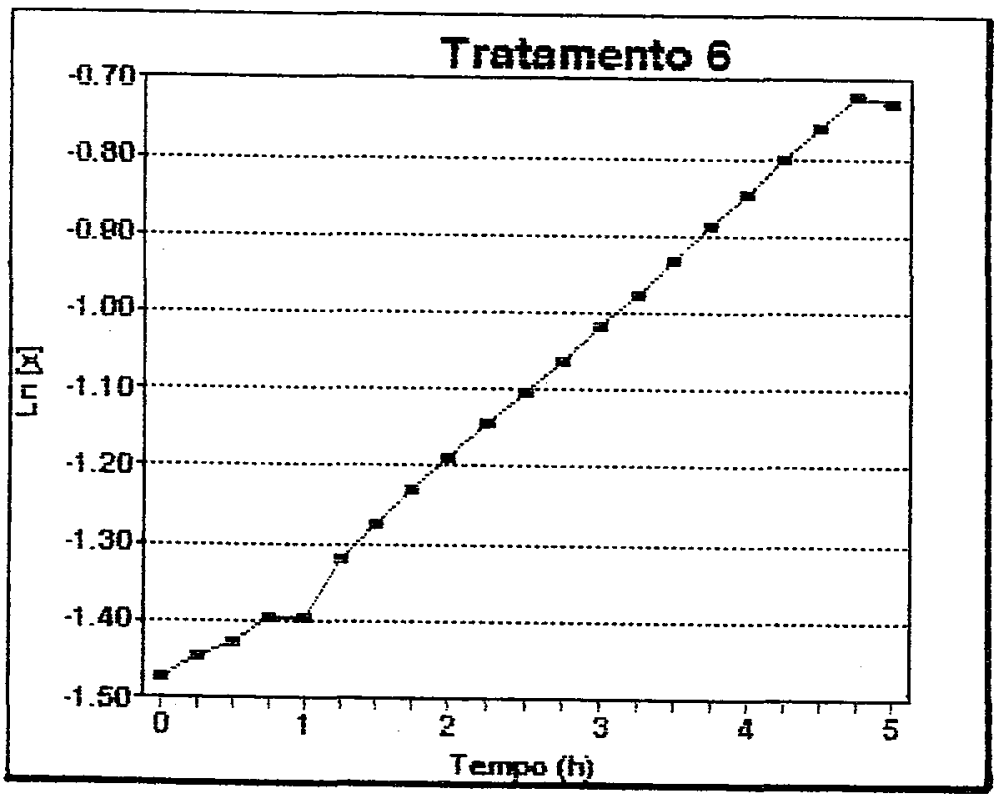

Figura 9. Curva de crescimento celular com $\mu_{\max }=0,1593 \mathrm{~h}^{-1}$ Período de tempo do cálculo de $\mu_{\max }=1 \mathrm{~h} 15-4 \mathrm{~h} 45$ 


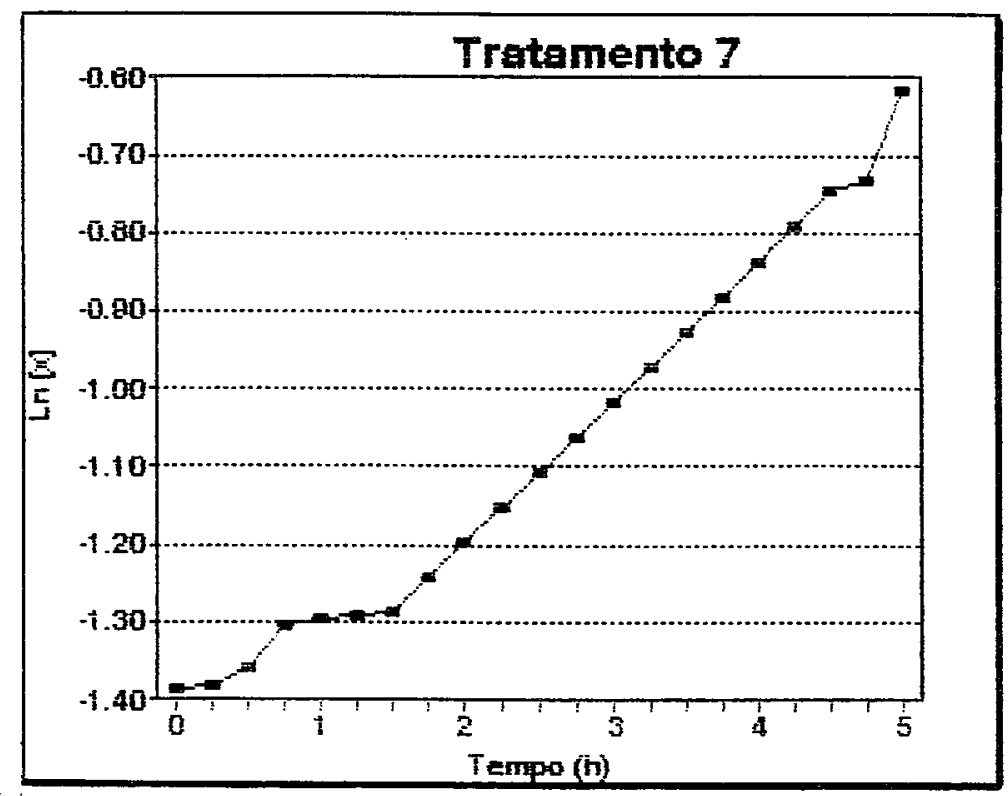

Figura 10. Curva de crescimento celular com $\mu_{\operatorname{máx}}=0,1654 \mathrm{~h}^{-1}$ Período de tempo do cálculo de $\mu_{\max }=1 \mathrm{~h} 30-4 \mathrm{~h} 30$

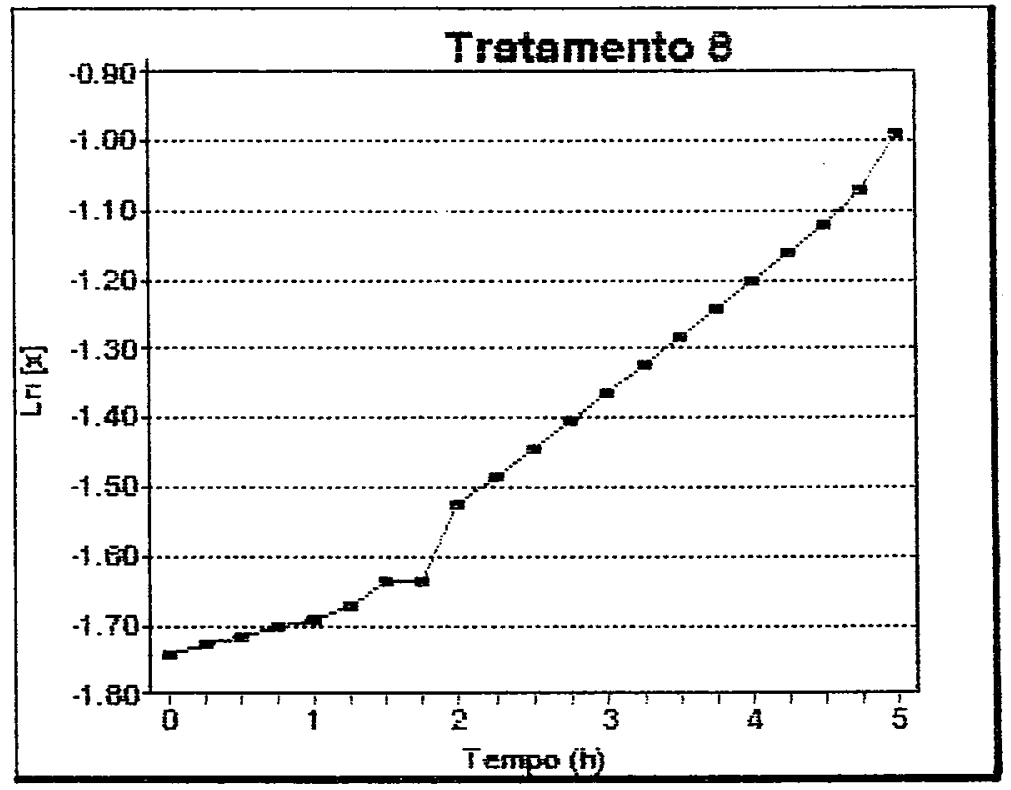

Figura 11. Curva de crescimento celular com $\mu_{\operatorname{máx}}=0,1468 \mathrm{~h}^{-1}$ Período de tempo do cálculo de $\mu_{\mathrm{max}}=2 \mathrm{~h} 00-4 \mathrm{~h} 45$ 


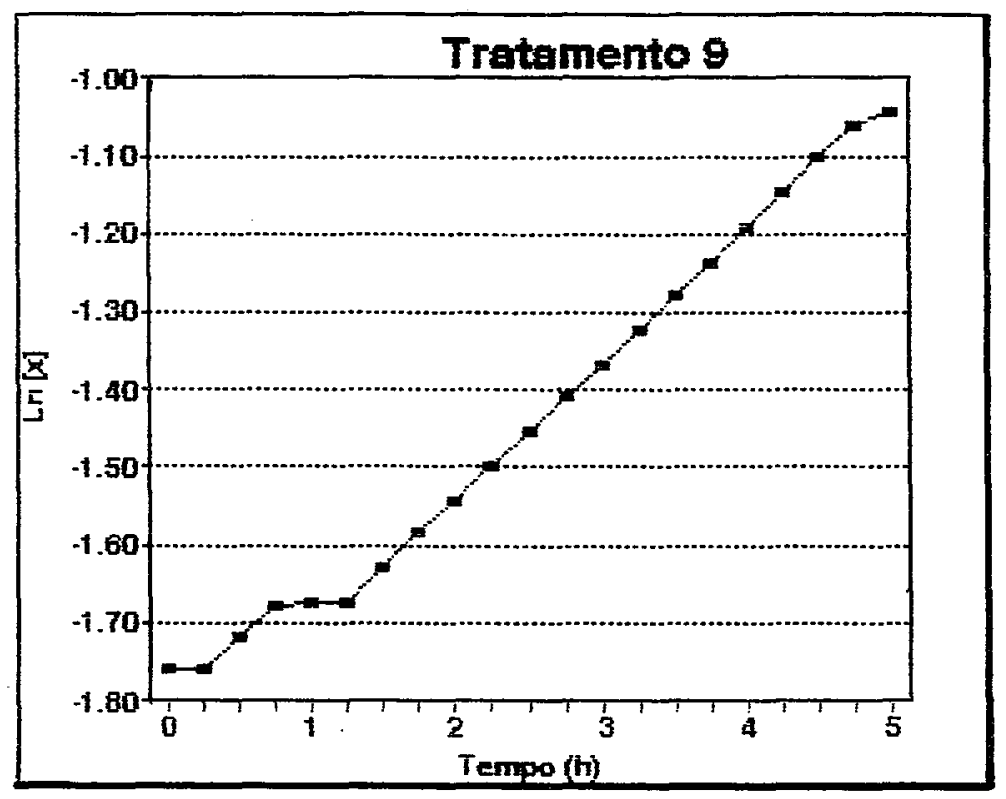

Figura 12. Curva de crescimento celular com $\mu_{\operatorname{máx}}=0,1634 \mathrm{~h}^{-1}$ Período de tempo do cálculo de $\mu_{\text {máx }}=1 \mathrm{~h} 15-4 \mathrm{~h} 45$

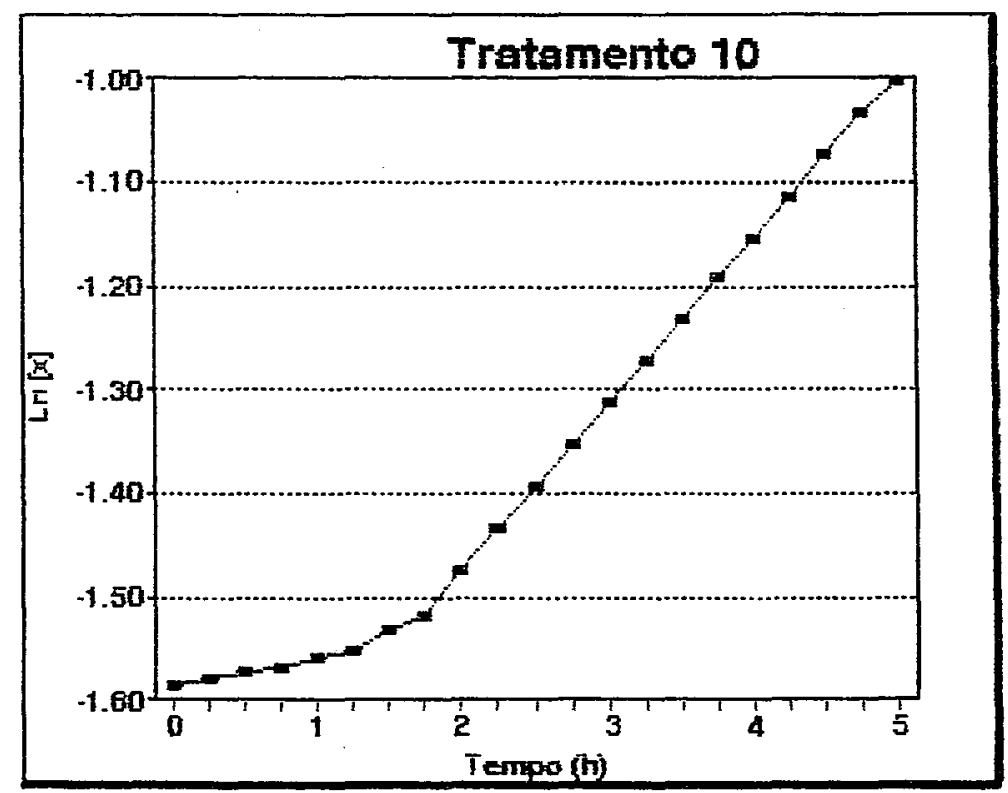

Figura 13. Curva de crescimento celular com $\mu_{\operatorname{máx}}=0,1477 \mathrm{~h}^{-1}$ Período de tempo do cálculo de $\mu_{\text {máx }}=2 \mathrm{~h} 00-4 \mathrm{~h} 45$ 


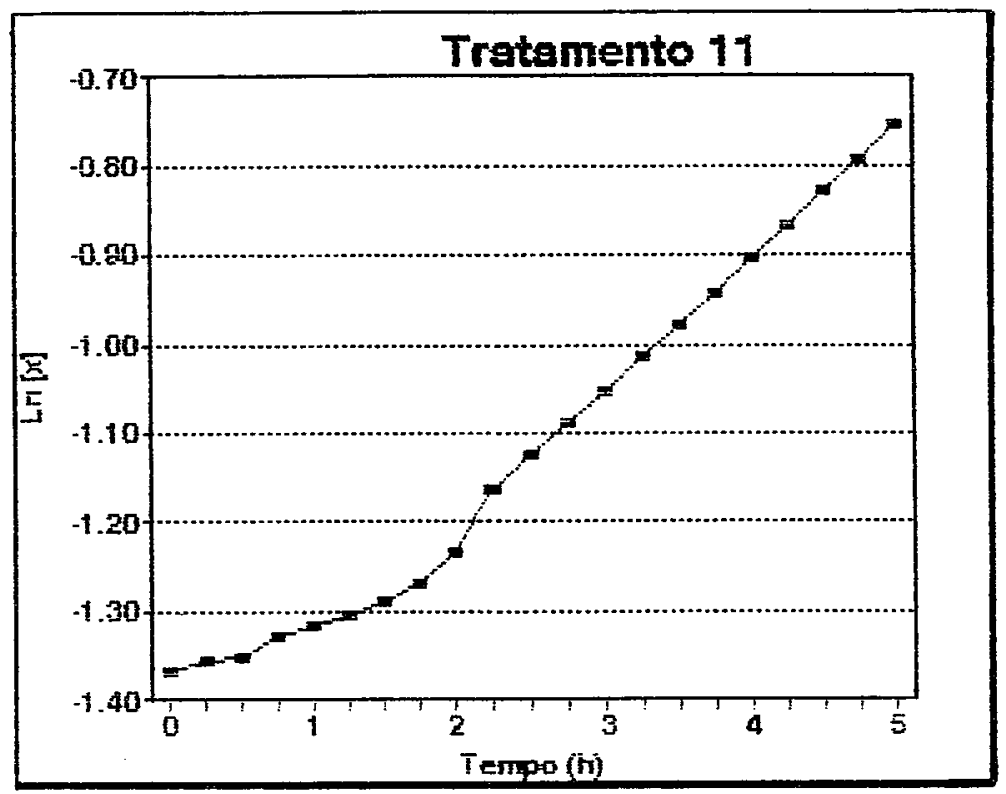

Figura 14. Curva de crescimento celular com $\mu_{\operatorname{máx}}=0,1355 \mathrm{~h}^{-1}$ Período de tempo do cálculo de $\mu_{\operatorname{máx}}=2 \mathrm{~h} 15-5 \mathrm{~h} 00$

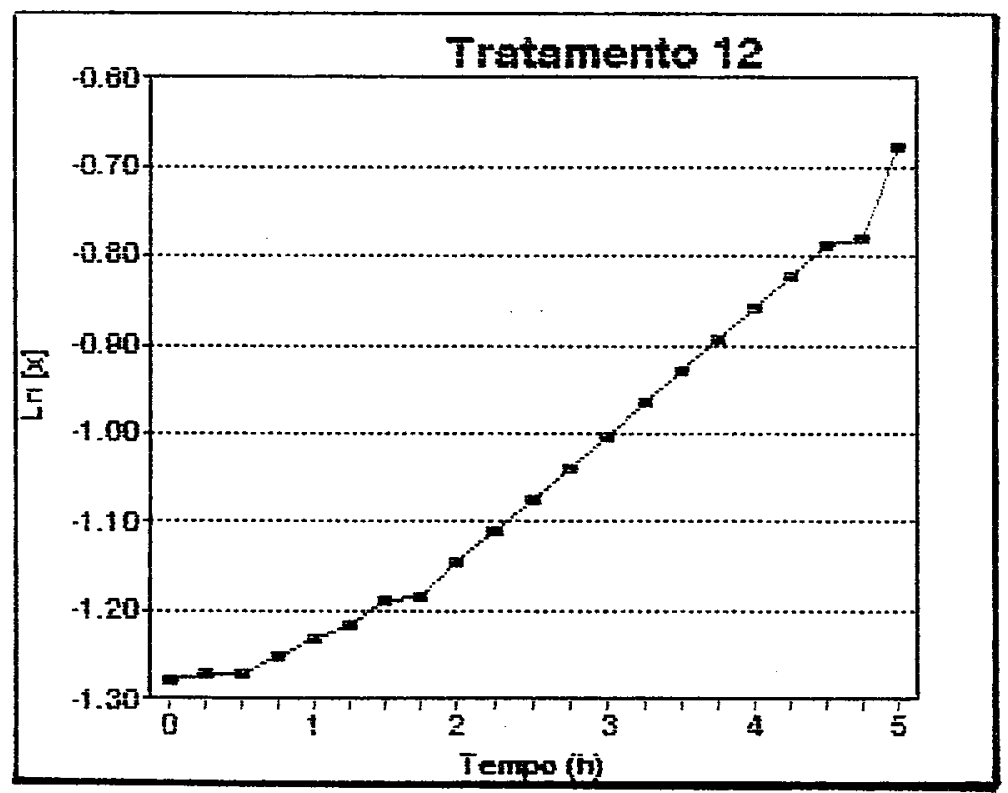

Figura 15. Curva de crescimento celular com $\mu_{\max }=0,1321 \mathbf{h}^{-1}$ Período de tempo do cálculo de $\mu_{\max }=1 \mathrm{~h} 45-4 \mathrm{~h} 30$ 


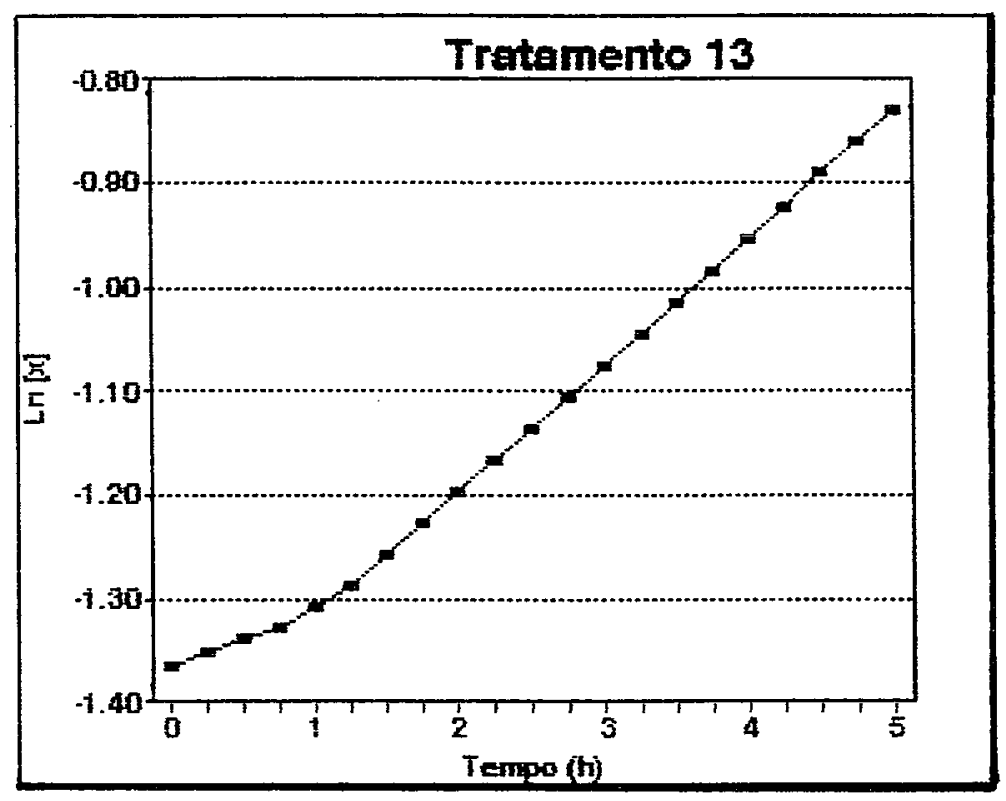

Figura 16. Curva de crescimento celular com $\mu_{\max }=0,1141 \mathrm{~h}^{-1}$ Período de tempo do cálculo de $\mu_{\max }=1$ h30 - 5 h00

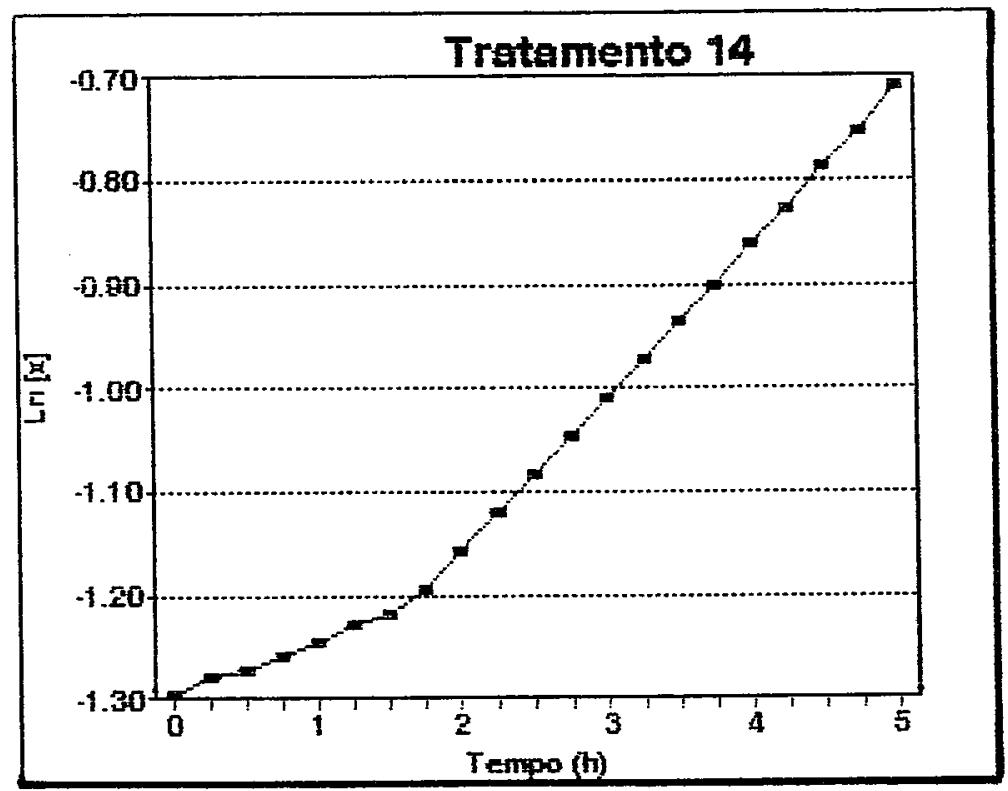

Figura 17. Curva de crescimento celular com $\mu_{\operatorname{máx}}=0,1362 \mathrm{~h}^{-1}$ Período de tempo do cálculo de $\mu_{\max }=1 \mathrm{~h} 45-4 \mathrm{~h} 45$ 


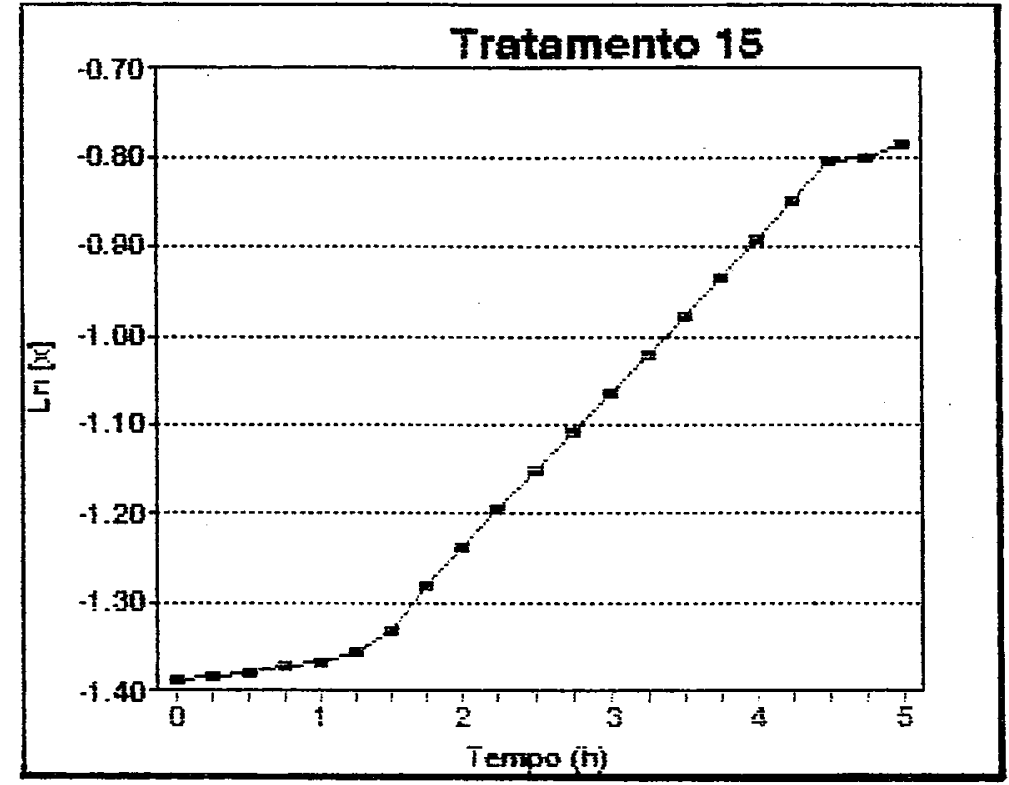

Figura 18. Curva de crescimento celular com $\mu_{\max }=0,1576 \mathrm{~h}^{-1}$ Período de tempo do cálculo de $\mu_{\max }=1 \mathrm{~h} 45-4 \mathrm{~h} 30$ 


\section{CONCLUSÕES}

O presente trabalho, avaliando, por parâmetros não convencionais a presença de leveduras contaminantes de processos de produção de etanol, permite-nos concluir:

- Considerando as condições do experimento, o rendimento em etanol não foi um parâmetro adequado para se detectar a presença de contaminantes, mesmo quando se combinou diferentes linhagens de leveduras.

- O rendimento em massa celular é uma boa indicação do comportamento de linhagens de leveduras quando cultivadas separadamente.

- A combinação das diversas linhagens, resultou em menor produção de massa celular em relação às culturas puras e não foi possível identificar a influência de uma ou de outra linhagem para a maioria dos tratamentos.

- Os dados do presente trabalho indicam que em culturas mistas o $\mu_{\text {máx }}$ é menor do que em linhagens cultivadas em cultura pura.

- Pode-se observar também que quanto maior o número de linhagens num mesmo cultivo, a velocidade específica de crescimento máxima reduz consideravelmente.

- De acordo com os dados obtidos, o $\mu_{\text {máx }}$ é um bom parâmetro para avaliar a presença de possíveis contaminantes. 


\section{REFERÊNCIAS BIBLIOGRÁFICAS}

AMORIM, H.V.; ZAGO, E.A.; OLIVEIRA, A.J. Novos métodos para o controle da fermentação alcoólica. São Paulo, Sociedade Brasileira de Microbiologia, 1982. $58 \mathrm{p}$.

ALVES, D.M.G. Fatores que afetam a produção de ácidos orgânicos bem como parâmetros da fermentação alcoólica. Piracicaba, 1993. 280 p. (Mestrado - Escola Superior de Agricultura "Luiz de Queiroz"/USP).

BARNETT, J.A.; PAYNE, R.W.; YARROW, D. Yeast: characteristics and identification. Cambridge, Cambridge University Press, 1983. 811p.

BENDOVÁ, O.; RICHTER, V.; JANDEROVÁ, B.; HAUSLER, J. Identification of industrial yeast strains of Saccharomyces cerevisiae by fatty acid profiles. Applied Microbiology and Biotechnology, Berlin, 35:810-2, 1991.

BORZANI, W. Objective criteria to confirm the existence of the exponential growth phase in a batch microbial process. Revista de Microbiologia, São Paulo, 24(4):278-80, 1993.

BUSSEY, H. Physiology of killer factor in yeast. Advances in Microbiology and Phisiology, London, 22:93-122, 1981.

CAMPBELL, I. Microbiology of brewing: beer and lager. In: NORRIS, J.R. \& PETTIPHER, G.L. eds. Essays in agricultural and food microbiology. Chichester, New York, 1987a.

CAMPBELL, I. Wild yeasts in brewing and distiling. In: PRIEST, F.G. \& CAMPBELL, I., eds., Brewing microbiology, London, Elsevier, 1987b. cap. 7, p. 187-205. 
COCHRAN, W.G. \& COX, S.M. Experimental designs. New York, Wiley International, 1957. $611 \mathrm{p}$.

COOPERATIVA DE PRODUTORES DE CANA, AÇÚCAR E ÁlCOOL DO ESTADO DE SÃo PAULO. Centro de Tecnologia. Divisão Industrial. Fermentação. São Paulo, COPERSUCAR, 1987. $434 \mathrm{p}$.

DAY, A. Rapid detection of microbial spoilage. In: PRIEST, F.G. \& CAMPBELL, I., edts. Brewing Microbiology, London, Elsevier. 1987. p. 207-31.

DAY, A. \& MEYLING, J.C. Practical experience with rapid methods of detecting yeasts in breweries. Journal of The Institute of Brewing, London, 89:204-206, 1983.

DEGRÉ, R; THOMAS, D.Y.; ASH, J.; MAILHIOT, K.; MORIN, A.; DUBORD, C. Wine yeasts strain identification. American Journal Enology Viticulture, Davis, 40(4):309- 315, 1989.

FLOWERS, T.H. \& WILLIAMS, S.T. Measurement of growth rates of streptomycetes: comparison of turbidimetric and gravimetric techniques. Journal General Microbiology, London, 98:285-9, 1977.

FREDRICKSON, A.G. Behaviour of mixed cultures of microorganisms. Annual Review of Microbiology, Palo Alto, 31:63-87, 1977.

GILLILAND, R.B. Yeast classification. Journal of The Institute of Brewing, London, 77:276-284, 1971.

GORIN, P.A.J. \& SPENCER, J.F.T. Proton magnetic resonance spectroscopy an aid in identification and chemotaxonomy of yeasts. Advances in Applied Microbiology, New York, 13:25-89, 1970.

GRIFFITHS, A.J. A numericlature of the yeasts. Antonie van Leeuwenhock, Amsterdam, 47:547-563, 1981. 
GUINARD, J-X \& LEWIS, M.J. Study of the phenomenon of agglomeration in the yeast Saccharomyces cerevisiae. Journal of the Institute of Brewing, London, 99:487-503. Nov-Dec/1993.

GUTIERREZ, L.E. Estudo comparativo da fermentação alcoólica por linhagens de Saccharomyces cerevisiae e Saccharomyces uvarum. Piracicaba, 1989, 160 p. (Livre-Docência - Escola Superior de Agricultura "Luiz de Queiroz"/USP).

GUTIERREZ, L.E. Acúmulo de trealose em linhagens de Saccharomyces durante fermentação alcoólica. Anais da Escola Superior de Agricultura "Luiz de Queiroz", Piracicaba, 47(2):597-608, 1990.

GUTIERREZ, L.E. Tópicos de bioquímica de leveduras. Piracicaba, ESALQ/Núcleo de Apoio à Pesquisa em Microbiologia Agrícola, 1994. 103 p. (NAPMA Publicação, 1).

HALL, J.F. Detection of wild yeasts in the brewery. Journal of The Institute of Brewing, London, 77:513-516, 1971.

HARALDSON, A. \& BJÖRLING, T. Yeast strains for concentrated substrates. European Journal Applied Microbiology Biotechnology, Berlin, 13:34-38. 1981.

HARRISON, J.S. Yeasts in baking: factors affecting changes in behaviour. Journal of Applied Bacteriology, Oxford, 34:173-179, 1971.

HAUKELI, A.D. \& LIE, S. Experimental conditions affecting yeast growth. Journal of the Institute of Brewing, London, 77:253-8. 1971.

HENSCHKE, P.A. \& THOMAS, D.S. Detection of wine-spoiling yeasts by electronic methods. Journal of Applied Bacteriology, Oxford, 64:123-133, 1988.

HINCHLIFFE, E. Developing new strains of yeast. Journal of the Institute of Brewing, London, 98:27-31, 1992. 
HOWARD, G.A. Recommended methods of analysis. Journal of the Institute of Brewing, London, 77:181-226, 1971.

KILIAN, S.G.; DEEMTER, A.; KOCK, J.L.F.; PREEZ, J.C. Ocurrence and toxonomic aspecto of proton movements coupled to sugar transport in the yeast genus Kluyveromyces. Antonie van Leeuwenhock, Amsterdam, 59:199-206, 1991.

KURTZMAN, C.P. \& PHAFF, H.J. Molecular taxonomy. In: ROSE, A.H. \& HARRISON, J.S. eds. The yeasts. London, Academic Press, 1987. v. 1, p. 6394.

LEVEAU, J.Y. \& BOUIX, M. Cinéticas microbianas. In: Scriban, R., coord. Biotecnologia. São Paulo, Manole. 1985. p.103-23.

MAULE, A.P. \& THOMAS, P.D. Strains of yeast lethal to brewery yeasts. Journal of the Institute of Brewing, London, 79:137-141, 1973.

MILLER, R. \& GALSTON, G. Rapid methods for the detection of yeast and Lactobacillus by ATP bioluminescence. Journal of The Institute of Brewing, London, 95:317-319, 1989.

NORDSTRÖM, K. Formation of ethyl acetate in fermentation with brewer's yeast. IV Metabolism of acetyl-coenzyme A. Journal of The Institute of Brewing, London, 69:142-53, 1963.

NORDSTRÖM, K. Formation of ethyl acetate in fermentation with brewer's yeast. V Effect of some vitamins and mineral nutrients. Journal of The Institute of Brewing, London, 70:209-21, 1964.

OLIVEIRA, M.C.F.L. Leveduras contaminantes da fermentação etanólica. In: Microbiologia da fermentação etanólica. Rio Claro, UNESP/Depto. Bioquímica, 1987. p. 92-104.

PAMMENT, N.B. \& HALL, R.J. Absence of external causes of lag in Saccharomyces cerevisiae. The Journal of General Microbiology, London, 105(2):297-304, 1978. 
PAMMENT, N.B.; HALL, R.J.; BARFORD, J.P. Mathematical modeling of lag phases in microbial growth. Biotechnology and Bioengineering, 20:349-381, 1978.

PELCZAR, M.; REID, R.; CHAN, E.C.S. Microbiologia. São Paulo, McGraw-Hill, 1980. v. 1. 566 p.

PETERING, J.E.; SYMONS, M.R.; LANGRIDGE, P.; HENSCHKE, P.A. Determination of killer yeast activity in fermenting grape juice by using a marked Saccharomyces wine yeast strain. Applied and Enviromental Microbiology, Berlin, 57(11):3232-3236, 1991.

PHAFF, H.J.; MILLER, M.W.; MRAK, E.M. Yeast spoilage of foods and fermentation processes. In: .The life of yeasts. Cambridge, Harvard University Press, 1978. $341 \mathrm{p}$.

PIERCE, J.S. Institute of brewing: analysis committee measurament of yeast viability. Journal of the Institute of Brewing, Cambridge, 76(5):442-3, 1970.

PIRT, S.J. Principles of microbe and cell cultivation. Oxford, Blackwell Scientifc Publ., 1975. 274 p.

QUAIN, D.E. Diferentiation of brewing yeast. Journal of The Institute of Brewing, London, 92:435-437, 1986.

RICHARDS, M. The use of giant-colony morphology for the differentiation of brewing yeasts. Journal of The Institute of Brewing, London, 73:162-166, 1967.

RODRIGUES, M.I. Desenvolvimento de técnicas para o controle da fermentação . In: REUNIÃo TÉCNICA SOBRE FERMENTAÇÃo AlCOÓLICA. 1., Piracicaba, COPERSUCAR, 1989. Anais. s.n.t.. p. 27-37.

RODRIGUEZ, S.B. A system for identifying spoilage yeast in packaged wine. American Journal Enology Viticulture, Davis, 38(4):273-276, 1987.

SATO, H.H.; PASTORE, G.M.; PARK, Y.K. Study of some characteristics of newly isolated Killer yeast. Revista de Microbiologia, São Paulo, 24(1): 71-2, 1993. 
SHEEHAN, C.A. \& WEISS, A.S. Brewing Yeast identification and chromosome analysis using high resolution CHEF gel Electrophoresis. Journal of The Institute of Brewing, London, 97:163-167, 1991.

SHEHATA, A.M.E. Yeast isolated from sugar cane and its juice during the production of aguardente de cana. Applied Microbiology, Berlin, 8:73-5, 1960.

SIMPSON, W.J.; FERNANDEZ, J.L.; HAMMOND, J.R.M. Differentiation of brewery yeasts using a disc-diffusion test. Journal of The Institute of Brewing, London, 98:33-36, 1992.

SOMERS, J.M. \& BEVAN, E.A. The inheritance of the killer character in yeast. Genetical Research, London, 13:71-83, 1969.

STANBURY, P.F. \& WHITAKER, A. Principles of fermentation technology. Oxford, Pergamon Press, 1984. 255 p.

STELLE, D.B. \& STOWERS, M.D. Techniques for selection of industrially important microorganisms. Annual Review of Microbiology, Palo Alto, 45:89-106, 1991.

TAVARES, F.C.A. Processo de controle seletivo de leveduras contaminantes. STAB. Açúcar, Álcool e Subprodutos, Piracicaba, 10(5):45-49, 1992.

TAVARES, F.C.A.; ECHEVERRIGARAY, S.; GOMES, L.H.; SOUBIHE, M. Identificação molecular de leveduras da fermentação alcoólica. STAB. Açúcar, Álcool e Subprodutos, Piracicaba, 10(4):34-39, 1992.

THORNTON, R.J. \& BUNKER, A. Characterization of wine yeasts for genetically modifiable properties. Journal of The Institute of Brewing, London, 95:181$184,1989$. 
TREDOUX, H.G.; KOCK, J.L.F.; LATEGAN, P.M.; MULLER, H.B. A rapid identification technique to differentiate between Saccharomyces cerevisiae strains and other yeast species in the wine industry. American Journal Enology Viticulture, Davis, 38(2):161-164, 1987.

TSUCHIYA, T.; FUKAZAWA, Y.; KAWAKITA, S. Significance of serological studies on yeasts. Mycologia Applicata, Amsterdam, 26:1-5, 1965.

VAN OEVELEN, D.; SPAEPEN, M.; TIMMERMANS, P.; VERACHTERT, H. Microbiological aspects of spontaneous wort fermentation in the production of lambic and gueuze. Journal of The Institute of Brewing, London, 83:356-360, Nov.-Dec./1977.

VAN VURREN, H.J.J. \& VAN DER MEER, L.J. Characterization of brewing yeast strains by numerical analysis of total soluble cell protein patterns. Journal of The Institute of Brewing, London, 94:245-8, 1988.

VISSER, W; SCHEFFERS, A; BATENBURG-VAN DER VEGTE, W.H.; VAN DIJKEN, J.P. Oxygen requirements of yeasts. Applied and Enviromental Microbiology. Berlin, 56(12):3785-92. Dec/1990.

WALSH, R.M. \& MARTIN, P.A. Growth of Saccharomyces cerevisiae and Saccharomyces uvarum in a temperature gradient incubator. Journal of the Institute of Brewing, London, 83:169-172. May-Jun/1977.

WILSON, K. \& McLEOD, B.J. The influence of condition of growth on the endogenous metabolism of Saccharomyces cerevisiae: effect on protein, carbohidrate, sterol and fatty acid cotent and on viability. Antonie van Leeuwenhoek, Amsterdam, 42:397-410, 1976.

WOODS, D.R. \& BEVAN, E.A. Studies on the nature of killer factor produced by Saccharomyces cerevisiae. Journal General Microbiology, London, 51:115126, 1968. 
YAMADA, Y.; NOJIRI, M.; MATSUYAMA, M.; KONDO, K. Co-enzyme Q system in the classification of the ascosporogenous yeast genera Debaryomyces, Saccharomyces, Kluyveromyces and Endomycopsis. Journal General Applied Microbiology, Tokyo, 22:325-39, 1976. 


\section{APÊNDICE 1}

\section{Curvas de Calibração utilizadas nos ensaios de crescimento celular}

\begin{tabular}{|c|c|c|c|c|c|c|c|c|c|}
\hline \multicolumn{2}{|c|}{$\begin{array}{c}\text { TRATAMENTO } \\
1\end{array}$} & \multicolumn{2}{|c|}{$\begin{array}{c}\text { TRATAMENTO } \\
\mathbf{2} \\
\end{array}$} & \multicolumn{2}{|c|}{$\begin{array}{c}\text { TRATAMENTO } \\
3 \\
\end{array}$} & \multicolumn{2}{|c|}{$\begin{array}{c}\text { TRATAMENTO } \\
4 \\
\end{array}$} & \multicolumn{2}{|c|}{ TRATAMENTO 5} \\
\hline Absorb. & $\begin{array}{l}\text { Conc. } \\
\text { cel.(g) }\end{array}$ & Absorb. & $\begin{array}{l}\text { Conc. } \\
\text { cel.(g) }\end{array}$ & Absorb & $\begin{array}{l}\text { Conc. } \\
\text { cel.(g) }\end{array}$ & Absorb & $\begin{array}{l}\text { Conc. } \\
\text { cel.(g) }\end{array}$ & Absorb. & $\begin{array}{l}\text { Conc. } \\
\text { cel.(g) }\end{array}$ \\
\hline 0.091 & 0.04 & 0.080 & 0.07 & 0.080 & 0.05 & 0.083 & 0.09 & 0.104 & 0.10 \\
\hline 0.168 & 0.17 & 0.139 & 0.20 & 0.132 & 0.16 & 0.140 & 0.12 & 0.191 & 0.17 \\
\hline 0.241 & 0.26 & 0.194 & 0.30 & 0.183 & 0.23 & 0.191 & 0.20 & 0.280 & 0.35 \\
\hline 0.302 & 0.41 & 0.247 & 0.40 & 0.234 & 0.35 & 0.241 & 0.25 & 0.347 & 0.48 \\
\hline 0.373 & 0.46 & 0.298 & 0.52 & 0.285 & 0.44 & 0.291 & 0.37 & 0.424 & 0.60 \\
\hline 0.429 & 0.62 & 0.345 & 0.61 & 0.330 & 0.59 & 0.333 & 0.43 & 0.484 & 0.76 \\
\hline 0.484 & 0.69 & 0.386 & 0.69 & 0.371 & 0.65 & 0.380 & 0.53 & 0.547 & 0.83 \\
\hline 0.531 & 0.82 & 0.431 & 0.78 & 0.413 & 0.68 & 0.422 & 0.60 & 0.597 & 0.96 \\
\hline 0.581 & 0.98 & 0.475 & 0.88 & 0.455 & 0.81 & 0.464 & 0.73 & 0.653 & 1.13 \\
\hline 0.625 & 1.07 & 0.509 & 0.90 & 0.495 & 0.94 & 0.497 & 0.85 & 0.684 & 1.25 \\
\hline \multicolumn{2}{|c|}{$\mathbf{r}=0.9915$} & \multicolumn{2}{|c|}{$\mathrm{r}=0.9990$} & \multicolumn{2}{|c|}{$\begin{array}{l}r=0.9956 \\
c=0.0646+c\end{array}$} & \multicolumn{2}{|c|}{$\begin{array}{l}\mathrm{r}=0.9838 \\
\mathrm{C}=\mathbf{0 . 0 8 2 8 + 0 . 5 3 1 0 x}\end{array}$} & \multicolumn{2}{|c|}{$\begin{array}{l}r=0.9915 \\
C=0.0997+0.4998 x\end{array}$} \\
\hline
\end{tabular}

\begin{tabular}{|c|c|c|c|c|c|c|c|c|c|}
\hline \multicolumn{2}{|c|}{$\begin{array}{c}\text { TRATAMENTO } \\
6 \\
\end{array}$} & \multicolumn{2}{|c|}{$\begin{array}{c}\text { TRATAMENTO } \\
7 \\
\end{array}$} & \multicolumn{2}{|c|}{$\begin{array}{c}\text { TRATAMENTO } \\
8 \\
\end{array}$} & \multicolumn{2}{|c|}{$\begin{array}{c}\text { TRATAMENTO } \\
9\end{array}$} & \multicolumn{2}{|c|}{$\begin{array}{c}\text { TRATAMENTO } \\
10\end{array}$} \\
\hline Absorb. & $\begin{array}{l}\text { Conc. } \\
\text { cel.(g) }\end{array}$ & Absorb. & $\begin{array}{l}\text { Conc. } \\
\text { cel.(g) }\end{array}$ & Absorb & $\begin{array}{l}\text { Conc. } \\
\text { cel.(g) }\end{array}$ & Absorb. & $\begin{array}{l}\text { Conc. } \\
\text { cel.(g) }\end{array}$ & Absorb. & $\begin{array}{l}\text { Conc. } \\
\text { cel.(g) }\end{array}$ \\
\hline 0.107 & 0.08 & 0.094 & 0.05 & 0.080 & 0.07 & 0.080 & 0.10 & 0.094 & 0.06 \\
\hline 0.199 & 0.27 & 0.170 & 0.13 & 0.151 & 0.21 & 0.146 & 0.16 & 0.169 & 0.21 \\
\hline 0.283 & 0.33 & 0.240 & 0.29 & 0.212 & 0.32 & 0.206 & 0.34 & 0.246 & 0.44 \\
\hline 0.354 & 0.50 & 0.310 & 0.34 & 0.256 & 0.39 & 0.265 & 0.37 & 0.309 & 0.51 \\
\hline 0.435 & 0.64 & 0.369 & 0.50 & 0.329 & 0.56 & 0.320 & 0.55 & 0.371 & 0.59 \\
\hline 0.493 & 0.76 & 0.428 & 0.56 & 0.386 & 0.67 & 0.370 & 0.65 & 0.425 & 0.69 \\
\hline 0.562 & 0.90 & 0.489 & 0.67 & 0.436 & 0.80 & 0.418 & 0.81 & 0.477 & 0.88 \\
\hline 0.614 & 1.00 & 0.542 & 0.83 & 0.486 & 0.92 & 0.464 & 0.89 & 0.529 & 1.04 \\
\hline 0.658 & 1.24 & 0.584 & 0.98 & 0.529 & 1.01 & 0.506 & 0.92 & 0.573 & 1.10 \\
\hline 0.703 & 1.39 & 0.619 & 1.06 & 0.572 & 1.16 & 0.547 & 1.00 & 0.616 & 1.23 \\
\hline \multicolumn{2}{|c|}{$\mathrm{r}=0.9843$} & \multicolumn{2}{|c|}{$r=0.9879$} & \multicolumn{2}{|c|}{$r=0.9972$} & \multicolumn{2}{|l|}{$\begin{array}{l}r=0.992 \\
C=0.0555+\end{array}$} & \multicolumn{2}{|c|}{$\begin{array}{l}r=0.9934 \\
C=0.0775+0.4994 x\end{array}$} \\
\hline
\end{tabular}




\begin{tabular}{|c|c|c|c|c|c|c|c|c|c|}
\hline \multicolumn{2}{|c|}{$\begin{array}{c}\text { TRATAMENTO } \\
11 \\
\end{array}$} & \multicolumn{2}{|c|}{$\begin{array}{c}\text { TRATAMENTO } \\
12 \\
\end{array}$} & \multicolumn{2}{|c|}{$\begin{array}{c}\text { TRATAMENTO } \\
13 \\
\end{array}$} & \multicolumn{2}{|c|}{$\begin{array}{c}\text { TRATAMENTO } \\
14 \\
\end{array}$} & \multicolumn{2}{|c|}{$\begin{array}{c}\text { TRATAMENTO } \\
15 \\
\end{array}$} \\
\hline Absorb. & $\begin{array}{l}\text { Conc. } \\
\text { cel.(g) }\end{array}$ & Absorb. & $\begin{array}{l}\text { Conc. } \\
\text { cel.(g) }\end{array}$ & Absorb & $\begin{array}{l}\text { Conc. } \\
\text { cel.(g) }\end{array}$ & Absorb. & $\begin{array}{l}\text { Conc. } \\
\text { cel.(g) }\end{array}$ & Absorb. & $\begin{array}{l}\text { Conc. } \\
\text { cel. (g) }\end{array}$ \\
\hline 0.115 & 0.13 & 0.121 & 0.09 & 0.093 & 0.05 & 0.100 & 0.08 & 0.079 & 0.05 \\
\hline 0.198 & 0.20 & 0.218 & 0.25 & 0.170 & 0.21 & 0.183 & 0.24 & 0.151 & 0.15 \\
\hline 0.275 & 0.28 & 0.298 & 0.38 & 0.242 & 0.34 & 0.257 & 0.33 & 0.228 & 0.30 \\
\hline 0.348 & 0.51 & 0.373 & 0.51 & 0.309 & 0.47 & 0.326 & 0.43 & 0.291 & 0.42 \\
\hline 0.412 & 0.65 & 0.446 & 0.69 & 0.372 & 0.59 & 0.393 & 0.57 & 0.353 & 0.54 \\
\hline 0.481 & 0.85 & 0.511 & 0.82 & 0.427 & 0.72 & 0.448 & 0.63 & 0.406 & 0.62 \\
\hline 0.535 & 1.01 & 0.575 & 0.94 & 0.480 & 0.88 & 0.505 & 0.81 & 0.463 & 0.78 \\
\hline 0.583 & 1.07 & 0.623 & 1.12 & 0.533 & 0.99 & 0.555 & 0.90 & 0.507 & 0.87 \\
\hline 0.637 & 1.25 & 0.670 & 1.23 & 0.578 & 1.13 & 0.607 & 1.07 & 0.551 & 0.93 \\
\hline 0.680 & 1.35 & 0.716 & 1.42 & 0.621 & 1.28 & 0.647 & 1.18 & 0.592 & 1.08 \\
\hline \multicolumn{2}{|c|}{$r=0.9910$} & \multicolumn{2}{|c|}{$\mathrm{r}=0.9916$} & \multicolumn{2}{|c|}{$\begin{array}{l}r=0.9952 \\
c=0.0928+\end{array}$} & \multicolumn{2}{|c|}{$\begin{array}{l}r=0.9901 \\
C=0.0896+0.5008 x\end{array}$} & \multicolumn{2}{|c|}{$\begin{array}{l}r=0.9969 \\
C=0.0748+0.5005 x\end{array}$} \\
\hline
\end{tabular}




\section{APÊNDICE 2}

\section{DADOS ORIGINAIS}

\section{TRATAMENTO 1}

\begin{tabular}{|lcccccccc|}
\hline PROPAGAÇÃO & Bloco 2 & Bloco 3 & Bloco 4 & Bloco 6 & Bloco 9 & Bloco 11 & Bloco 12 & Bloco 13 \\
\hline & & & & & & & & \\
Peso Erlen. vazio (g) & 183.00 & 182.50 & 206.50 & 182.50 & 182.50 & 194.50 & 194.50 & 184.00 \\
Peso Erlen. esteril. (g) & 383.00 & 382.50 & 407.00 & 382.50 & 382.50 & 394.50 & 394.50 & 384.00 \\
Peso Erlen. c/ inóc. (g) & 395.50 & 394.00 & 417.00 & 393.50 & 393.00 & 406.00 & 407.00 & 395.50 \\
Peso Erlen após inc. (g) & 388.00 & 388.00 & 408.00 & 389.50 & 387.00 & 400.00 & 400.00 & 389.00 \\
pH inicial & 5.60 & 5.60 & 5.60 & 5.60 & 5.60 & 5.60 & 5.60 & 5.60 \\
pH final & 4.15 & 4.13 & 4.18 & 4.20 & 4.20 & 4.18 & 4.14 & 4.21 \\
Viabilidade (\%) & 98.42 & 98.65 & 99.28 & 99.46 & 98.25 & 99.51 & 98.65 & 98.97 \\
ART final (\%) & 3.3686 & 3.1837 & 4.3224 & 4.3500 & 4.3750 & 3.4177 & 3.7448 & 3.1388 \\
Etanol (v/v) & 2.56 & 2.56 & 2.42 & 2.56 & 2.56 & 2.56 & 2.56 & 2.56 \\
Etanol (g/g) & 2.02 & 2.02 & 1.92 & 2.02 & 2.02 & 2.02 & 2.02 & 2.02 \\
Peso Massa Seca (g) & 0.00481 & 0.00482 & 0.00313 & 0.00385 & 0.00380 & 0.00377 & 0.00319 & 0.00421 \\
Células/m1 10 & 4.9 & 5.0 & 4.8 & 5.1 & 5.1 & 4.9 & 5.4 & 5.3 \\
\hline
\end{tabular}

\begin{tabular}{|lcccccccc|}
\hline FERMENTAÇÃO & Bloco 2 & Bloco 3 & Bloco 4 & Bloco 6 & Bloco 9 & Bloco 11 & Bloco 12 & Bloco 13 \\
\hline & & & & & & & & \\
Peso Erlen. vazio (g) & 219.50 & 218.50 & 190.00 & 189.50 & 190.50 & 205.00 & 206.00 & 206.00 \\
Peso Erlen. esteril. (g) & 321.00 & 318.50 & 294.50 & 291.50 & 292.00 & 305.00 & 306.00 & 306.50 \\
Peso Erlen. c/ inóc. (g) & 322.00 & 320.00 & 295.50 & 293.50 & 294.50 & 305.50 & 307.00 & 307.50 \\
Peso Erlen após inc. (g) & 317.50 & 315.00 & 291.00 & 288.00 & 290.00 & 300.50 & 302.50 & 303.00 \\
pH inicial & 5.60 & 5.60 & 5.60 & 5.60 & 5.60 & 5.60 & 5.60 & 5.60 \\
pH final & 4.83 & 4.86 & 4.87 & 4.91 & 4.76 & 5.00 & 4.87 & 4.83 \\
ART final (\%) & 5.2551 & 5.2812 & 5.0056 & 5.2125 & 5.2036 & 5.3235 & 5.2156 & 5.3183 \\
Etanol (v/v) & 4.06 & 4.48 & 3.24 & 4.06 & 3.24 & 4.06 & 4.06 & 4.06 \\
Etanol (g/g) & 3.22 & 3.56 & 2.56 & 3.22 & 2.56 & 3.22 & 3.22 & 3.22 \\
Peso Massa Seca (g) & 0.00779 & $\mathbf{0 . 0 0 7 5 4}$ & $\mathbf{0 . 0 0 8 8 1}$ & 0.00758 & $\mathbf{0 . 0 0 7 3 3}$ & $\mathbf{0 . 0 0 6 6 3}$ & 0.00796 & 0.00619 \\
ART meio 3 (\%) & 14.3644 & $\mathbf{1 4 . 1 2 2 4}$ & 13.7712 & 13.2500 & 13.2589 & 14.1772 & 13.8075 & 12.2909 \\
\hline
\end{tabular}




\section{TRATAMENTO 2}

\begin{tabular}{|lcccccccc|}
\hline PROPAGAÇÃO & Bloco 1 & Bloco 3 & Bloco 5 & Bloco 10 & Bloco 11 & Bloco 12 & Bloco 13 & Bloco 15 \\
\hline & & & & & & & & \\
Peso Erlen. vazio(g) & 182.50 & 189.50 & 204.00 & 205.00 & 205.50 & 205.50 & 194.50 & 221.00 \\
Peso Erlen. esteril. (g) & 384.00 & 389.50 & 405.50 & 405.00 & 406.50 & 405.50 & 394.50 & 421.00 \\
Peso Erlen. c/ inóc. (g) & 395.50 & 402.00 & 418.00 & 418.00 & 419.00 & 417.50 & 405.00 & 433.50 \\
Peso Erlen após inc. (g) & 387.50 & 392.00 & 409.50 & 408.50 & 409.00 & 408.00 & 396.50 & 423.50 \\
pH inicial & 5.60 & 5.60 & 5.60 & 5.60 & 5.60 & 5.60 & 5.60 & 5.60 \\
pH final & 3.92 & 3.95 & 3.97 & 3.97 & 3.94 & 3.78 & 3.68 & 3.85 \\
Viabilidade (\%) & 99.61 & 99.22 & 99.33 & 97.18 & 98.89 & 98.14 & 96.57 & 99.11 \\
ART final (\%) & 0.2342 & 0.1959 & 0.3068 & 0.2631 & 0.3908 & 0.2144 & 0.2009 & 0.2165 \\
Etanol (v/v) & 4.48 & 4.48 & 4.48 & 4.90 & 4.90 & 4.76 & 4.48 & 5.04 \\
Etanol (g/g) & 3.56 & 3.56 & 3.56 & 3.88 & 3.88 & 3.78 & 3.56 & 4.00 \\
Peso Massa Seca (g) & 0.00619 & 0.00644 & 0.00579 & 0.00604 & 0.00559 & 0.00435 & 0.00480 & 0.00597 \\
Células/ml 108 & 2.8 & 3.5 & 1.6 & 1.9 & 2.0 & 2.6 & 1.3 & 2.4 \\
\hline
\end{tabular}

\begin{tabular}{|lcccccccc|}
\hline FERMENTAÇÃO & Bloco 1 & Bloco 3 & Bloco 5 & Bloco 10 & Bloco11 & Bloco 12 & Bloco 13 & Bloco 15 \\
\hline & & & & & & & & \\
Peso Erlen. vazio (g) & 209.00 & 200.00 & 188.50 & 183.00 & 183.50 & 214.00 & 214.00 & 214.00 \\
Peso Erlen. esteril. (g) & 310.00 & 300.00 & 289.00 & 283.00 & 283.50 & 314.00 & 316.00 & 315.50 \\
Peso Erlen. c/ inóc. (g) & 312.50 & 302.50 & 290.00 & 284.00 & 285.00 & 315.50 & 316.50 & 317.00 \\
Peso Erlen após inc. (g) & 306.00 & 294.50 & 283.00 & 277.50 & 278.00 & 309.50 & 311.00 & 309.50 \\
pH inicial & 5.60 & 5.60 & 5.60 & 5.60 & 5.60 & 5.60 & 5.60 & 5.60 \\
pH final & 3.85 & 3.88 & 3.89 & 3.88 & 3.98 & 3.71 & 3.88 & 3.81 \\
ART final (\%) & 0.3447 & 0.2967 & 0.5023 & 0.3629 & 0.2677 & 0.3473 & 0.2651 & 0.3249 \\
Etanol (v/v) & 6.42 & 5.86 & 6.14 & 6.28 & 6.00 & 6.28 & 6.86 & 6.00 \\
Etanol (g/g) & 5.10 & 4.66 & 4.88 & 5.00 & 4.78 & 5.00 & 5.44 & 4.78 \\
Peso Massa Seca (g) & 0.00999 & 0.01130 & 0.00990 & 0.01042 & 0.00782 & 0.01123 & 0.00874 & 0.01052 \\
ART meio 3 (\%) & 14.4726 & 14.1224 & 13.3636 & 15.0000 & 14.1772 & 13.8075 & 12.2909 & 14.0157 \\
\hline
\end{tabular}




\section{TRATAMENTO 3}

\begin{tabular}{|lcccccccc|}
\hline PROPAGAÇÃO & Bloco 1 & Bloco 2 & Bloco 3 & Bloco 6 & Bloco 8 & Bloco 11 & Bloco 14 & Bloco 15 \\
\hline & & & & & & & & \\
Peso Erlen. vazio (g) & 184.50 & 183.50 & 188.00 & 186.50 & 209.50 & 220.50 & 184.00 & 194.00 \\
Peso Erlen. esteril. (g) & 385.00 & 383.50 & 391.50 & 388.50 & 410.00 & 420.50 & 384.00 & 394.00 \\
Peso Erlen. c/ inóc. (g) & 396.50 & 393.50 & 403.00 & 400.00 & 420.00 & 429.50 & 394.00 & 406.00 \\
Peso Erlen após inc. (g) & 389.00 & 384.00 & 392.00 & 391.50 & 412.50 & 420.50 & 384.50 & 396.00 \\
pH inicial & 5.60 & 5.60 & 5.60 & 5.60 & 5.60 & 5.60 & 5.60 & 5.60 \\
pH final & 3.90 & 3.87 & 3.99 & 4.00 & 4.02 & 4.01 & 3.94 & 3.78 \\
Viabilidade (\%) & 99.17 & 98.56 & 99.60 & 95.86 & 97.95 & 98.69 & 99.24 & 98.05 \\
ART final (\%) & 0.2236 & 0.2002 & 0.3220 & 0.3761 & 0.3167 & 0.5000 & 0.4244 & 0.2278 \\
Etanol (v/v) & 4.48 & 4.76 & 4.48 & 4.62 & 4.76 & 4.76 & 4.48 & 4.76 \\
Etanol (g/g) & 3.56 & 3.78 & 3.56 & 3.66 & 3.78 & 3.78 & 3.56 & 3.78 \\
Peso Massa Seca (g) & 0.00655 & 0.00687 & 0.00511 & 0.00446 & 0.00559 & 0.00530 & 0.00585 & 0.00593 \\
Células/ml 10 & 3.3 & 3.0 & 1.7 & 3.8 & 2.9 & 3.9 & 2.2 & 2.8 \\
\hline
\end{tabular}

\begin{tabular}{|lcccccccc|}
\hline FERMENTAÇÃO & Bloco 1 & Bloco 2 & Bloco 4 & Bloco 5 & Bloco 6 & Bloco 9 & Bloco 10 & Bloco 15 \\
\hline & & & & & & & & \\
Peso Erlen. vazio (g) & 206.00 & 200.50 & 207.00 & 188.00 & 201.00 & 213.00 & 214.50 & 206.00 \\
Peso Erlen. esteril. (g) & 307.00 & 300.50 & 312.50 & 291.50 & 301.00 & 314.00 & 314.50 & 307.50 \\
Peso Erlen. c/ inóc. (g) & 309.00 & 301.00 & 313.00 & 293.00 & 303.00 & 316.00 & 316.00 & 309.50 \\
Peso Erlen após inc. (g) & 302.00 & 293.50 & 308.00 & 286.50 & 296.00 & 310.00 & 308.00 & 303.00 \\
pH inicial & 5.60 & 5.60 & 5.60 & 5.60 & 5.60 & 5.60 & 5.60 & 5.60 \\
pH final & 3.83 & 3.83 & 3.88 & 3.90 & 3.98 & 4.16 & 4.13 & 3.80 \\
ART final (\%) & 0.3234 & 0.3130 & 0.4801 & 0.5182 & 0.4125 & 0.4999 & 0.3966 & 0.3059 \\
Etanol (v/v) & 6.42 & 5.86 & 5.86 & 5.58 & 6.56 & 6.21 & 5.72 & 6.56 \\
Etanol (g/g) & 5.10 & 4.66 & 4.66 & 4.44 & 5.22 & 5.94 & 4.54 & 5.22 \\
Peso Massa Seca (g) & $\mathbf{0 . 0 1 0 1 8}$ & 0.01104 & $\mathbf{0 . 0 0 9 4 6}$ & $\mathbf{0 . 0 0 9 9 5}$ & $\mathbf{0 . 0 0 9 2 8}$ & $\mathbf{0 . 0 1 0 1 0}$ & $\mathbf{0 . 0 0 9 7 8}$ & $\mathbf{0 . 0 1 4 7 7}$ \\
ART meio 3 (\%) & 14.4726 & 14.3644 & 13.7712 & 13.3636 & 13.2500 & 13.2589 & 15.0000 & 14.0157 \\
\hline
\end{tabular}




\section{TRATAMENTO 4}

\begin{tabular}{|c|c|c|c|c|c|c|c|c|}
\hline PROPAGAÇÃO & Bloco 1 & Bloco 2 & Bloco 4 & Bloco 5 & Bloco 6 & Bloco 9 & Bloco 10 & Bloco 15 \\
\hline Peso Erlen. vazio (g) & 189.50 & 190.00 & 188.00 & 193.50 & 191.00 & 209.50 & 194.00 & 190.00 \\
\hline Peso Erlen. esteril. (g) & 389.50 & 390.00 & 388.00 & 397.00 & 391.00 & 409.50 & 394.00 & 390.00 \\
\hline Peso Erlen. c/ inóc. (g) & 400.50 & 401.50 & 400.00 & 407.50 & 404.00 & 422.00 & 406.50 & 400.00 \\
\hline Peso Erlen após inc. (g) & 392.50 & 391.50 & 390.50 & 400.50 & 395.00 & 413.50 & 399.00 & 391.00 \\
\hline pH inicial & 5.60 & 5.60 & 5.60 & 5.60 & 5.60 & 5.60 & 5.60 & 5.60 \\
\hline pH final & 3.78 & 3.76 & 3.77 & 3.93 & 3.56 & 3.83 & 3.55 & 3.71 \\
\hline Viabilidade (\%) & 98.63 & 97.82 & 96.84 & 99.22 & 98.25 & 98.96 & 98.93 & 98.41 \\
\hline ART final (\%) & 0.3924 & 0.2754 & 0.3153 & 0.6958 & 0.7857 & 1.2827 & 0.4449 & 0.5315 \\
\hline Etanol (v/v) & 5.04 & 4.62 & 4.48 & 4.62 & 4.62 & 4.48 & 4.76 & 5.04 \\
\hline Etanol $(g / g)$ & 4.00 & 3.66 & 3.56 & 3.66 & 3.66 & 3.56 & 3.78 & 4.00 \\
\hline Peso Massa Seca (g) & 0.00489 & 0.00520 & 0.00511 & 0.00383 & 0.00449 & 0.00383 & 0.00507 & 0.00443 \\
\hline Células/ml $10^{8}$ & 4.0 & 4.4 & 6.1 & 3.1 & 3.7 & 2.6 & 3.6 & 4.4 \\
\hline
\end{tabular}

\begin{tabular}{|c|c|c|c|c|c|c|c|c|}
\hline FERMENTAÇÃO & Bloco 1 & Bloco 2 & Bloco 3 & Bloco 6 & Bloco 8 & Bloco 11 & Bloco 14 & Bloco 15 \\
\hline Peso Erlen. vazio (g) & 219.00 & 206.00 & 190.50 & 219.00 & 214.50 & 189.50 & 189.00 & 209.50 \\
\hline Peso Erlen. esteril. (g) & 320.50 & 306.50 & 291.00 & 321.50 & 315.50 & 289.50 & 290.00 & 310.00 \\
\hline Peso Erlen. c/ inóc. (g) & 321.50 & 308.50 & 293.50 & 323.50 & 317.00 & 290.00 & 291.50 & 311.00 \\
\hline Peso Erlen após inc. (g) & 315.50 & 302.00 & 286.00 & 317.00 & 310.00 & 282.50 & 284.50 & 304.50 \\
\hline pH inicial & 5.60 & 5.60 & 5.60 & 5.60 & 5.60 & 5.60 & 5.60 & 5.60 \\
\hline pH final & 3.81 & 3.83 & 3.82 & 3.97 & 3.65 & 3.99 & 3.81 & 3.77 \\
\hline ART final (\%) & 0.3213 & 0.3235 & 0.3008 & 0.3812 & 0.3143 & 0.3050 & 0.2951 & 0.3291 \\
\hline $\operatorname{Etanol}(v / v)$ & 6.28 & 6.00 & 5.86 & 6.70 & 6.28 & 6.42 & 6.28 & 6.86 \\
\hline Etanol $(g / g)$ & 5.00 & 4.78 & 4.66 & 5.34 & 5.00 & 5.10 & 5.00 & 5.44 \\
\hline Peso Massa Seca (g) & 0.00811 & 0.00957 & 0.01026 & 0.00745 & 0.00775 & 0.00563 & 0.00810 & 0.01004 \\
\hline ART meio $3(\%)$ & 14.4726 & 14.3644 & 14.1224 & 13.2500 & 13.1429 & 14.1772 & 13.7551 & 14.0157 \\
\hline
\end{tabular}




\section{TRATAMENTO 5}

\begin{tabular}{|lrrrrrrrr|}
\hline PROPAGAÇÃO & Bloco 1 & Bloco 4 & Bloco 8 & Bloco 9 & Bloco 12 & Bloco 13 & Bloco 14 & Bloco 15 \\
\hline & & & & & & & & \\
Peso Erlen. vazio(g) & 194.00 & 184.50 & 209.50 & 209.00 & 183.50 & 190.00 & 190.50 & 182.50 \\
Peso Erlen. esteril. (g) & 394.00 & 388.50 & 412.00 & 410.50 & 383.50 & 390.00 & 392.00 & 382.50 \\
Peso Erlen. c/ inóc. (g) & 406.00 & 400.00 & 424.00 & 423.00 & 395.00 & 403.00 & 404.00 & 394.00 \\
Peso Erlen após inc. (g) & 397.00 & 389.00 & 414.50 & 413.00 & 384.50 & 394.00 & 397.00 & 383.50 \\
pH inicial & 5.60 & 5.60 & 5.60 & 5.60 & 5.60 & 5.60 & 5.60 & 5.60 \\
pH final & 3.89 & 4.08 & 3.73 & 4.12 & 3.72 & 3.71 & 3.68 & 3.74 \\
Viabilidade (\%) & 98.10 & 98.16 & 98.57 & 98.19 & 96.66 & 96.96 & 98.63 & 98.61 \\
ART final (\%) & 0.2120 & 0.3284 & 0.4036 & 0.3125 & 0.2129 & 0.2045 & 0.2357 & 0.2293 \\
Etanol (v/v) & 4.76 & 4.62 & 4.76 & 4.48 & 4.90 & 4.76 & 4.76 & 5.04 \\
Etanol (g/g) & 3.78 & 3.66 & 3.78 & 3.56 & 3.88 & 3.78 & 3.78 & 4.00 \\
Peso Massa Seca (g) & 0.00574 & 0.00557 & 0.00538 & 0.00590 & 0.00379 & 0.00568 & 0.00539 & 0.00572 \\
Células/ml 10 & 2.8 & 2.9 & 3.8 & 3.3 & 1.9 & 2.5 & 3.2 & 3.9 \\
\hline
\end{tabular}

\begin{tabular}{|lrrrrrrrr|}
\hline FERMENTAÇÃO & Bloco 1 & Bloco 4 & Bloco 8 & Bloco 9 & Bloco 12 & Bloco 13 & Bloco 14 & Bloco 15 \\
\hline & & & & & & & & \\
Peso Erlen. vazio (g) & 183.50 & 183.00 & 184.00 & 182.50 & 183.50 & 209.00 & 183.50 & 184.00 \\
Peso Erlen. esteril. (g) & 285.00 & 287.50 & 284.50 & 282.50 & 383.50 & 310.00 & 284.00 & 284.00 \\
Peso Erlen. c/ inóc. (g) & 286.50 & 288.00 & 286.00 & 283.50 & 384.00 & 312.00 & 285.50 & 285.50 \\
Peso Erlen após inc. (g) & 279.50 & 282.50 & 279.50 & 277.50 & 278.50 & 305.00 & 278.50 & 278.00 \\
pH inicial & 5.60 & 5.60 & 5.60 & 5.60 & 5.60 & 5.60 & 5.60 & 5.60 \\
pH final & 4.03 & 4.04 & 3.92 & 4.09 & 3.80 & 3.77 & 3.97 & 4.09 \\
ART final (\%) & 0.3170 & 0.4690 & 0.2571 & 0.4541 & 0.3389 & 0.3132 & 0.2885 & 0.3165 \\
Etanol (v/v) & 6.00 & 6.21 & 6.28 & 5.86 & 6.28 & 6.42 & 6.28 & 6.14 \\
Etanol (g/g) & 4.78 & 5.94 & 5.00 & 4.66 & 5.00 & 5.10 & 5.00 & 4.88 \\
Peso Massa Seca (g) & $\mathbf{0 . 0 0 9 8 2}$ & 0.00872 & 0.01014 & 0.00998 & 0.01017 & 0.00921 & 0.00936 & 0.01040 \\
ART meio 3 (\%) & 14.4726 & 13.7712 & 13.1429 & 13.2589 & 13.8075 & 12.2909 & 13.7551 & 14.0157 \\
\hline
\end{tabular}




\section{TRATAMENTO 6}

\begin{tabular}{|c|c|c|c|c|c|c|c|c|}
\hline PROPAGAÇÃO & Bloco 2 & Bloco 5 & Bloco 6 & Bloco 8 & Bloco 10 & Bloco 12 & Bloco 13 & Bloco 14 \\
\hline Peso Erlen. vazio (g) & 194.50 & 220.50 & 187.50 & 206.50 & 209.50 & 183.00 & 183.00 & 183.00 \\
\hline Peso Erlen. esteril. (g) & 394.50 & 420.50 & 391.50 & 406.50 & 411.50 & 383.00 & 384.50 & 384.00 \\
\hline Peso Erlen. c/ inóc. (g) & 405.50 & 431.00 & 401.50 & 419.50 & 423.00 & 394.00 & 395.50 & 396.50 \\
\hline Peso Erlen após inc. (g) & 395.50 & 422.50 & 394.00 & 409.50 & 413.50 & 384.00 & 386.00 & 388.50 \\
\hline $\mathrm{pH}$ inicial & 5.60 & 5.60 & 5.60 & 5.60 & 5.60 & 5.60 & 5.60 & 5.60 \\
\hline pH final & 3.87 & 3.92 & 4.02 & 3.68 & 3.94 & 3.71 & 3.70 & 3.65 \\
\hline Viabilidade (\%) & 97.20 & 98.09 & 99.14 & 99.18 & 98.78 & 96.40 & 97.31 & 99.16 \\
\hline ART final (\%) & 0.2087 & 0.3250 & 0.3417 & 0.4440 & 0.3619 & 0.2238 & 0.2082 & 0.2388 \\
\hline Etanol (v/v) & 4.76 & 4.48 & 4.76 & 4.76 & 4.48 & 4.76 & 4.76 & 4.76 \\
\hline Etanol (g/g) & 3.78 & 3.56 & 3.78 & 3.78 & 3.56 & 3.78 & 3.78 & 3.78 \\
\hline Peso Massa Seca (g) & 0.00619 & 0.00495 & 0.00534 & 0.00558 & 0.00545 & 0.00431 & 0.00573 & 0.00569 \\
\hline Células $/ \mathrm{m} 1 \quad 10^{8}$ & 4.0 & 4.5 & 3.2 & 3.3 & 4.9 & 1.9 & 2.3 & 3.9 \\
\hline
\end{tabular}

\begin{tabular}{|c|c|c|c|c|c|c|c|c|}
\hline FERMENTAÇAOO & Bloco 2 & Bloco 5 & Bloco 6 & Bloco 8 & Bloco 10 & Bloco 12 & Bloco 13 & Bloco 14 \\
\hline Peso Erlen. vazio (g) & 191.00 & 204.50 & 183.50 & 190.00 & 200.00 & 218.50 & 200.50 & 200.50 \\
\hline Peso Erlen. esteril. (g) & 291.50 & 306.00 & 285.00 & 290.00 & 301.50 & 318.50 & 301.50 & 301.00 \\
\hline Peso Erlen. c/ inóc. (g) & 294.50 & 307.00 & 287.50 & 291.00 & 302.00 & 319.50 & 303.50 & 303.00 \\
\hline Peso Erlen após inc. (g) & 287.50 & 297.00 & 279.00 & 285.00 & 294.50 & 313.00 & 296.50 & 294.50 \\
\hline pH inicial & 5.60 & 5.60 & 5.60 & 5.60 & 5.60 & 5.60 & 5.60 & 5.60 \\
\hline pH final & 4.04 & 4.11 & 4.11 & 3.93 & 4.15 & 3.79 & 3.87 & 3.97 \\
\hline ART final (\%) & 0.3256 & 0.4704 & 0.4000 & 0.4452 & 0.4571 & 0.3556 & 0.3012 & 0.3128 \\
\hline $\operatorname{Etanol}(v / v)$ & 5.86 & 6.14 & 6.28 & 6.28 & 5.86 & 6.70 & 6.42 & 6.28 \\
\hline Etanol $(g / g)$ & 4.66 & 4.88 & 5.00 & 5.00 & 4.66 & 5.34 & 5.10 & 5.00 \\
\hline Peso Massa Seca (g) & 0.01018 & 0.00930 & 0.00910 & 0.01039 & 0.00978 & 0.01086 & 0.00917 & 0.00966 \\
\hline ART meio $3(\%)$ & 14.3644 & 13.3636 & 13.2500 & 13.1429 & 15.0000 & 13.8075 & 12.2909 & 13.7551 \\
\hline
\end{tabular}




\section{TRATAMENTO 7}

\begin{tabular}{|lrrrrrrrr|}
\hline PROPAGAÇÃ $\boldsymbol{O}$ & Bloco 3 & Bloco 4 & Bloco 5 & Bloco 8 & Bloco 9 & Bloco 10 & Bloco 11 & Bloco 14 \\
\hline & & & & & & & & \\
Peso Erlen. vazio(g) & 205.00 & 193.50 & 194.00 & 194.50 & 194.00 & 180.00 & 182.00 & 187.00 \\
Peso Erlen. esteril. (g) & 405.00 & 397.00 & 395.00 & 396.50 & 394.50 & 380.00 & 382.00 & 387.00 \\
Peso Erlen. c/ inóc. (g) & 417.50 & 408.00 & 408.00 & 409.00 & 406.00 & 392.00 & 393.50 & 397.50 \\
Peso Erlen após inc. (g) & 409.00 & 400.00 & 400.00 & 399.50 & 397.50 & 383.00 & 386.50 & 389.50 \\
pH inicial & 5.60 & 5.60 & 5.60 & 5.60 & 5.60 & 5.60 & 5.60 & 5.60 \\
pH final & 3.81 & 4.07 & 3.86 & 3.73 & 4.05 & 4.00 & 4.04 & 3.62 \\
Viabilidade (\%) & 98.19 & 98.81 & 99.52 & 99.47 & 98.03 & 97.29 & 98.96 & 99.28 \\
ART final (\%) & 0.2816 & 1.1283 & 0.7185 & 0.6190 & 0.4018 & 0.4819 & 1.9918 & 0.7959 \\
Etanol (v/v) & 4.90 & 4.20 & 4.48 & 4.20 & 4.34 & 4.76 & 4.06 & 4.76 \\
Etanol (g/g) & 3.88 & 3.34 & 3.56 & 3.34 & 3.44 & 3.78 & 3.22 & 3.78 \\
Peso Massa Seca (g) & 0.00441 & 0.00428 & 0.00404 & 0.00481 & 0.00493 & 0.00479 & 0.00391 & 0.00401 \\
Células/ml 108 & 3.3 & 2.0 & 2.7 & 4.9 & 3.3 & 4.0 & 3.7 & 4.6 \\
\hline
\end{tabular}

\begin{tabular}{|c|c|c|c|c|c|c|c|c|}
\hline FERMENTAÇÃO & Bloco 3 & Bloco 4 & Bloco 5 & Bloco 8 & Bloco 9 & Bloco 10 & Bloco 11 & Bloco 14 \\
\hline Peso Erlen. vazio (g) & 189.00 & 201.00 & 217.50 & 190.00 & 189.50 & 189.00 & 189.50 & 214.00 \\
\hline Peso Erlen. esteril. (g) & 289.50 & 304.50 & 318.50 & 290.00 & 291.00 & 290.00 & 289.50 & 314.00 \\
\hline Peso Erlen. c/ inóc. (g) & 291.00 & 305.50 & 319.50 & 291.50 & 293.00 & 291.00 & 290.50 & 315.50 \\
\hline Peso Erlen após inc. (g) & 284.00 & 298.00 & 313.00 & 285.00 & 285.50 & 284.50 & 286.50 & 308.50 \\
\hline pH inicial & 5.60 & 5.60 & 5.60 & 5.60 & 5.60 & 5.60 & 5.60 & 5.60 \\
\hline pH final & 4.14 & 4.26 & 4.28 & 3.97 & 4.22 & 4.31 & 4.41 & 4.24 \\
\hline ART final (\%) & 0.3382 & 0.6261 & 0.4636 & 0.3929 & 0.5023 & 0.5452 & 0.6436 & 0.3833 \\
\hline Etanol (v/v) & 6.70 & 6.00 & 5.86 & 6.28 & 5.86 & 6.63 & 5.86 & 7.00 \\
\hline Etanol (g/g) & 5.34 & 4.78 & 4.66 & 5.00 & 4.66 & 5.28 & 4.66 & 5.56 \\
\hline Peso Massa Seca (g) & 0.00867 & 0.00798 & 0.00757 & 0.00877 & 0.00901 & 0.00814 & 0.00619 & 0.00673 \\
\hline ART meio $3(\%)$ & 14.1224 & 13.7212 & 13.3636 & 13.1429 & 13.2589 & 15.0000 & 14.1772 & 13.7551 \\
\hline
\end{tabular}




\section{TRATAMENTO 8}

\begin{tabular}{|lrrrrrrrr|}
\hline PROPAGAÇÃO & Bloco 4 & Bloco 6 & Bloco 7 & Bloco 8 & Bloco 10 & Bloco 11 & Bloco 13 & Bloco 15 \\
& & & & & & & & \\
Peso Erlen. vazio(g) & 210.00 & 221.50 & 215.50 & 221.00 & 191.00 & 191.00 & 221.00 & 205.00 \\
Peso Erlen. esteril. (g) & 413.50 & 422.00 & 416.00 & 424.50 & 393.00 & 391.00 & 422.00 & 405.00 \\
Peso Erlen. c/ inóc. (g) & 425.00 & 432.50 & 428.50 & 436.00 & 404.00 & 402.50 & 434.50 & 416.00 \\
Peso Erlen após inc. (g) & 414.00 & 425.50 & 420.50 & 426.50 & 395.50 & 393.00 & 425.50 & 406.00 \\
pH inicial & 5.60 & 5.60 & 5.60 & 5.60 & 5.60 & 5.60 & 5.60 & 5.60 \\
pH final & 3.95 & 4.03 & 3.76 & 3.75 & 3.99 & 3.87 & 3.70 & 3.80 \\
Viabilidade (\%) & 95.65 & 97.63 & 96.42 & 96.39 & 97.21 & 98.50 & 97.50 & 99.45 \\
ART final (\%) & 0.2881 & 0.2552 & 0.2668 & 0.3369 & 0.2369 & 0.3386 & 0.2118 & 0.2141 \\
Etanol (v/v) & 4.76 & 4.48 & 4.76 & 4.76 & 4.48 & 4.90 & 4.90 & 4.76 \\
Etanol (g/g) & 3.78 & 3.56 & 3.78 & 3.78 & 3.56 & 3.88 & 3.88 & 3.78 \\
Peso Massa Seca (g) & $\mathbf{0 . 0 0 4 5 8}$ & $\mathbf{0 . 0 0 5 3 1}$ & $\mathbf{0 . 0 0 5 6 8}$ & $\mathbf{0 . 0 0 5 8 0}$ & $\mathbf{0 . 0 0 6 2 7}$ & $\mathbf{0 . 0 0 5 3 7}$ & $\mathbf{0 . 0 0 4 7 3}$ & $\mathbf{0 . 0 0 6 5 2}$ \\
Células/ml 108 & 1.9 & 2.3 & 1.8 & 2.6 & 3.5 & 3.4 & 1.5 & 2.0 \\
\hline
\end{tabular}

\begin{tabular}{|lrrrrrrrr|}
\hline FERMENTAÇÃ̈O & Bloco 4 & Bloco 6 & Bloco 7 & Bloco 8 & Bloco 10 & Bloco 11 & Bloco 13 & Bloco 15 \\
& & & & & & & & \\
Peso Erlen. vazio (g) & 205.50 & 190.00 & 219.50 & 219.50 & 191.00 & 191.00 & 189.00 & 219.50 \\
Peso Erlen. esteril. (g) & 307.00 & 291.00 & 322.50 & 319.50 & 291.00 & 291.00 & 289.50 & 320.00 \\
Peso Erlen. c/ inóc. (g) & 308.00 & 292.50 & 324.00 & 322.00 & 292.50 & 292.00 & 290.00 & 322.00 \\
Peso Erlen após inc. (g) & 302.00 & 287.00 & 317.00 & 315.00 & 285.50 & 285.00 & 283.50 & 315.00 \\
pH inicial & 5.60 & 5.60 & 5.60 & 5.60 & 5.60 & 5.60 & 5.60 & 5.60 \\
pH final & 3.87 & 3.94 & 3.56 & 3.82 & 4.04 & 4.21 & 3.82 & 3.80 \\
ART final (\%) & 0.4690 & 0.4396 & 0.4579 & 0.4048 & 0.3262 & 0.2908 & 0.2892 & 0.3228 \\
Etanol (v/v) & 6.21 & 6.00 & 5.30 & 6.28 & 5.86 & 6.42 & 6.70 & 6.14 \\
Etanol (g/g) & 5.94 & 4.78 & 4.22 & 5.00 & 4.66 & 5.10 & 5.34 & 4.88 \\
Peso Massa Seca (g) & 0.00987 & 0.01007 & 0.01133 & 0.01002 & 0.01015 & 0.00662 & 0.00908 & 0.01167 \\
ART meio 3 (\%) & 13.7712 & 13.2500 & 12.9911 & 13.1429 & 15.0000 & 14.1772 & 12.2909 & 14.0157 \\
\hline
\end{tabular}




\section{TRATAMENTO 9}

\begin{tabular}{|lrrrrrrrr|}
\hline PROPAGAÇÃO & Bloco 2 & Bloco 3 & Bloco 7 & Bloco 8 & Bloco 9 & Bloco 10 & Bloco 12 & Bloco 15 \\
& & & & & & & & \\
Peso Erlen. vazio(g) & 187.00 & 186.50 & 184.00 & 187.00 & 186.50 & 221.00 & 190.50 & 183.50 \\
Peso Erlen. esteril. (g) & 388.00 & 388.00 & 385.00 & 389.00 & 386.50 & 422.00 & 390.50 & 383.50 \\
Peso Erlen. c/ inóc. (g) & 400.00 & 400.00 & 398.00 & 400.50 & 397.50 & 433.50 & 413.00 & 394.00 \\
Peso Erlen após inc. (g) & 390.00 & 391.50 & 389.00 & 391.50 & 389.00 & 423.50 & 394.00 & 384.00 \\
pH inicial & 5.60 & 5.60 & 5.60 & 5.60 & 5.60 & 5.60 & 5.60 & 5.60 \\
pH final & 3.89 & 3.89 & 3.79 & 3.74 & 4.36 & 3.95 & 3.70 & 3.80 \\
Viabilidade (\%) & 99.30 & 98.35 & 98.89 & 99.18 & 97.87 & 95.62 & 98.01 & 98.93 \\
ART final (\%) & 0.1939 & 0.1990 & 0.3004 & 0.3143 & 0.3125 & 0.2151 & 0.2029 & 0.2185 \\
Etanol (v/v) & 4.48 & 4.90 & 4.76 & 4.34 & 4.48 & 4.90 & 4.76 & 5.04 \\
Etanol (g/g) & 3.56 & 3.88 & 3.78 & 3.44 & 3.56 & 3.88 & 3.78 & 4.00 \\
Peso Massa Seca (g) & 0.00650 & 0.00628 & $\mathbf{0 . 0 0 5 2 6}$ & 0.00531 & 0.00612 & 0.00599 & 0.00390 & 0.00572 \\
Células/ml 10 & 3.9 & 3.6 & 2.5 & 2.7 & 3.3 & 4.8 & 1.6 & 3.9 \\
\hline
\end{tabular}

\begin{tabular}{|c|c|c|c|c|c|c|c|c|}
\hline FERMENTAÇÃO & Bloco 2 & Bloco 3 & Blaco 7 & Bloco 8 & Bloco 9 & Bloco 10 & Bloco 12 & Bloco 15 \\
\hline Peso Erlen. vazio (g) & 214.50 & 205.00 & 206.00 & 206.50 & 205.50 & 205.00 & 200.50 & 201.00 \\
\hline Peso Erlen. esteril. (g) & 315.50 & 307.00 & 309.50 & 307.00 & 307.50 & 307.00 & 301.00 & 302.00 \\
\hline Peso Erlen. c/ inóc. (g) & 318.00 & 309.50 & 312.00 & 309.00 & 310.50 & 308.50 & 302.00 & 303.50 \\
\hline Peso Erlen após inc. (g) & 311.00 & 302.00 & 304.50 & 303.00 & 303.50 & 302.00 & 294.50 & 295.50 \\
\hline pH inicial & 5.60 & 5.60 & 5.60 & 5.60 & 5.60 & 5.60 & 5.60 & 5.60 \\
\hline pH final & 3.86 & 3.85 & 3.59 & 3.70 & 3.99 & 3.95 & 3.78 & 3.80 \\
\hline ART final (\%) & 0.2962 & 0.2884 & 0.4684 & 0.4119 & 0.4564 & 0.3143 & 0.3222 & 0.3186 \\
\hline Etanol (v/v) & 6.42 & 6.42 & 5.86 & 6.14 & 5.86 & 6.42 & 6.70 & 6.70 \\
\hline Etanol (g/g) & 5.10 & 5.10 & 4.66 & 4.88 & 4.66 & 5.10 & 5.34 & 5.34 \\
\hline Peso Massa Seca (g) & 0.01049 & 0.01137 & 0.01015 & 0.00916 & 0.00964 & 0.00989 & 0.01062 & 0.01011 \\
\hline ART meio $3(\%)$ & 14.3644 & 14.1224 & 12.9911 & 13.1429 & 13.2589 & 15.0000 & 13.8075 & 14.0157 \\
\hline
\end{tabular}


TRATAMENTO 10

\begin{tabular}{|lrrrrrrrr|}
\hline PROPAGAÇÃO & Bloco 1 & Bloco 3 & Bloco 4 & Bloco 5 & Bloco 6 & Bloco 7 & Bloco 8 & Bloco 12 \\
& & & & & & & & \\
Peso Erlen. vazio(g) & 220.50 & 182.50 & 183.50 & 182.50 & 206.00 & 194.50 & 183.00 & 190.00 \\
Peso Erlen. esteril. (g) & 421.50 & 382.50 & 388.00 & 385.50 & 409.00 & 397.00 & 384.50 & 390.00 \\
Peso Erlen. c/ inóc. (g) & 433.50 & 394.50 & 400.50 & 399.00 & 420.50 & 409.00 & 396.00 & 401.00 \\
Peso Erlen após inc. (g) & 424.50 & 385.50 & 391.50 & 390.50 & 412.50 & 401.00 & 387.00 & 391.50 \\
pH inicial & 5.60 & 5.60 & 5.60 & 5.60 & 5.60 & 5.60 & 5.60 & 5.60 \\
pH final & 3.86 & 3.86 & 4.05 & 3.96 & 4.03 & 3.74 & 3.75 & 3.72 \\
Viabilidade (\%) & 98.87 & 98.00 & 98.92 & 97.77 & 99.65 & 99.26 & 97.81 & 97.36 \\
ART final (\%) & 0.2004 & 0.2000 & 0.3242 & 0.3182 & 0.3083 & 0.2780 & 0.3167 & 0.1925 \\
Etanol (v/v) & 4.90 & 4.06 & 4.76 & 4.62 & 4.62 & 4.90 & 4.27 & 4.90 \\
Etanol (g/g) & 3.88 & 3.22 & 3.78 & 3.66 & 3.66 & 3.88 & 3.39 & 3.88 \\
Peso Massa Seca (g) & 0.00619 & 0.00606 & $\mathbf{0 . 0 0 5 3 4}$ & 0.00566 & 0.00528 & $\mathbf{0 . 0 0 5 4 1}$ & $\mathbf{0 . 0 0 5 3 4}$ & 0.00458 \\
Células/ml 108 & 2.9 & 2.4 & 1.9 & 2.7 & 3.2 & 2.9 & 3.7 & 2.2 \\
\hline
\end{tabular}

\begin{tabular}{|lrrrrrrrr|}
\hline FERMENTAÇÃO & Bloco 1 & Bloco 3 & Bloco 4 & Bloco 5 & Bloco 6 & Bloco 7 & Bloco 8 & Bloco 12 \\
& & & & & & & & \\
Peso Erlen. vazio (g) & 200.50 & 208.00 & 189.50 & 190.00 & 191.00 & 200.50 & 200.50 & 209.00 \\
Peso Erlen. esteril. (g) & 302.00 & 308.00 & 291.00 & 291.50 & 293.00 & 304.00 & 301.50 & 309.50 \\
Peso Erlen. c/ inóc. (g) & 303.50 & 311.00 & 293.50 & 292.00 & 295.00 & 305.50 & 304.00 & 311.50 \\
Peso Erlen após inc. (g) & 296.00 & 304.00 & 287.50 & 286.00 & 285.50 & 298.00 & 296.00 & 305.00 \\
pH inicial & 5.60 & 5.60 & 5.60 & 5.60 & 5.60 & 5.60 & 5.60 & 5.60 \\
pH final & 3.86 & 3.82 & 3.87 & 3.90 & 3.96 & 3.60 & 3.84 & 3.67 \\
ART final (\%) & 0.3213 & 0.3070 & 0.4690 & 0.4523 & 0.4375 & 0.4658 & 0.3881 & 0.3222 \\
Etanol (v/v) & 6.00 & 5.86 & 6.14 & 5.72 & 6.14 & 6.14 & 6.14 & 6.28 \\
Etanol (g/g) & 4.78 & 4.66 & 4.90 & 4.54 & 4.90 & 4.90 & 4.90 & 5.00 \\
Peso Massa Seca (g) & 0.00940 & 0.01162 & 0.00970 & 0.00959 & 0.00965 & 0.01135 & 0.00999 & 0.01158 \\
ART meio 3 (\%) & 14.4726 & 14.1224 & 13.7712 & 13.3636 & 13.2500 & 12.9911 & 13.1429 & 13.8075 \\
\hline
\end{tabular}




\section{TRATAMENTO 11}

\begin{tabular}{|lrrrrrrrr|}
\hline PROPAGAÇÃO & Bloco 1 & Bloco 2 & Bloco 5 & Bloco 7 & Bloco 8 & Bloco 9 & Bloco 11 & Bloco 13 \\
& & & & & & & & \\
Peso Erlen. vazio (g) & 190.00 & 190.50 & 183.50 & 206.50 & 184.00 & 183.50 & 183.50 & 190.00 \\
Peso Erlen. esteril. (g) & 390.00 & 390.50 & 387.00 & 407.00 & 386.00 & 383.50 & 383.50 & 390.00 \\
Peso Erlen. c/ inóc. (g) & 401.50 & 402.00 & 399.50 & 416.50 & 398.00 & 394.00 & 396.00 & 403.00 \\
Peso Erlen após inc. (g) & 394.00 & 392.00 & 390.50 & 408.50 & 388.00 & 385.00 & 385.50 & 394.00 \\
pH inicial & 5.60 & 5.60 & 5.60 & 5.60 & 5.60 & 5.60 & 5.60 & 5.60 \\
pH final & 3.92 & 3.91 & 3.97 & 3.80 & 3.74 & 4.00 & 3.84 & 3.71 \\
Viabilidade (\%) & 98.42 & 98.13 & 96.16 & 98.83 & 98.07 & 98.59 & 84.75 & 96.96 \\
ART final (\%) & 0.2015 & 0.2002 & 0.2966 & 0.2724 & 0.2679 & 0.2969 & 0.2447 & 0.2045 \\
Etanol (v/v) & 4.76 & 4.48 & 4.62 & 4.90 & 4.34 & 4.76 & 4.90 & 4.76 \\
Etanol (g/g) & 3.78 & 3.78 & 3.66 & 3.88 & 3.44 & 3.78 & 3.88 & 3.78 \\
Peso Massa Seca (g) & 0.00657 & 0.00637 & 0.00576 & 0.00582 & 0.00535 & 0.00501 & 0.00514 & 0.00542 \\
Células/m1 108 & 3.1 & 3.8 & 2.3 & 3.7 & 3.1 & 2.3 & 3.2 & 2.5 \\
\hline
\end{tabular}

\begin{tabular}{|lrrrrrrrr|}
\hline FERMENTAÇÃ O & Bloco 1 & Bloco 2 & Bloco 5 & Bloco 7 & Bloco 8 & Bloco 9 & Bloco 11 & Bloco 13 \\
& & & & & & & & \\
Peso Erlen. vazio (g) & 189.50 & 190.00 & 182.50 & 191.50 & 191.50 & 200.50 & 201.00 & 209.00 \\
Peso Erlen. esteril. (g) & 290.50 & 291.00 & 282.50 & 293.00 & 291.50 & 303.00 & 301.00 & 310.00 \\
Peso Erlen. c/ inóc. (g) & 291.50 & 294.00 & 283.50 & 295.00 & 293.00 & 305.00 & 302.00 & 312.00 \\
Peso Erlen após inc. (g) & 286.00 & 287.50 & 277.00 & 288.00 & 286.00 & 296.50 & 294.00 & 305.00 \\
pH inicial & 5.60 & 5.60 & 5.60 & 5.60 & 5.60 & 5.60 & 5.60 & 5.60 \\
pH final & 4.03 & 4.00 & 4.10 & 3.74 & 3.85 & 4.07 & 4.11 & 3.77 \\
ART final (\%) & 0.3149 & 0.3046 & 0.5273 & 0.4710 & 0.3071 & 0.4541 & 0.2801 & 0.3032 \\
Etanol (v/v) & 6.14 & 6.42 & 5.72 & 6.42 & 6.00 & 6.28 & 6.42 & 6.42 \\
Etanol (g/g) & 4.88 & 5.10 & 4.54 & 5.10 & 4.78 & 5.00 & 5.10 & 5.10 \\
Peso Massa Seca (g) & 0.01031 & 0.01013 & 0.01010 & 0.01132 & 0.00969 & 0.01005 & 0.00782 & 0.00954 \\
ART meio 3 (\%) & 14.4726 & 14.3644 & 13.3636 & 12.9911 & 13.1429 & 13.2589 & 14.1772 & 12.2909 \\
\hline
\end{tabular}


TRATAMENTO 12

\begin{tabular}{|lrrrrrrrr|}
\hline PROPAGAÇÃO & Bloco 5 & Bloco 6 & Bloco 7 & Bloco 9 & Bloco 11 & Bloco 12 & Bloco 14 & Bloco 15 \\
& & & & & & & & \\
Peso Erlen. vazio (g) & 209.00 & 195.00 & 183.50 & 204.50 & 221.50 & 221.00 & 183.50 & 189.50 \\
Peso Erlen. esteril. (g) & 413.00 & 395.00 & 383.50 & 405.00 & 422.00 & 421.00 & 384.50 & 390.00 \\
Peso Erlen. c/ inóc. (g) & 425.50 & 405.00 & 397.00 & 417.00 & 435.00 & 433.00 & 397.50 & 402.50 \\
Peso Erlen após inc. (g) & 417.00 & 398.50 & 388.00 & 408.50 & 425.00 & 423.00 & 389.00 & 392.00 \\
pH inicial & 5.60 & 5.60 & 5.60 & 5.60 & 5.60 & 5.60 & 5.60 & 5.60 \\
pH final & 4.00 & 4.02 & 3.77 & 4.10 & 3.91 & 3.73 & 3.65 & 3.74 \\
Viabilidade (\%) & 97.32 & 99.65 & 97.84 & 96.87 & 98.65 & 94.33 & 98.86 & 98.13 \\
ART final (\%) & 0.2966 & 0.2979 & 0.2803 & 0.3069 & 0.2257 & 0.2113 & 0.2439 & 0.2165 \\
Etanol (v/v) & 4.62 & 4.76 & 4.62 & 4.90 & 4.90 & 4.90 & 5.04 & 4.90 \\
Etanol (g/g) & 3.66 & 3.78 & 3.66 & 3.88 & 3.88 & 3.88 & 4.00 & 3.88 \\
Peso Massa Seca (g) & 0.00599 & 0.00501 & 0.00561 & 0.00571 & 0.00579 & 0.00415 & 0.00589 & 0.00576 \\
Células/m1 108 & 2.8 & 3.7 & 2.7 & 2.4 & 3.3 & 1.8 & 3.8 & 3.8 \\
\hline
\end{tabular}

\begin{tabular}{|lrrrrrrrr|}
\hline FERMENTAÇÃ $\boldsymbol{O}$ & Bloco 5 & Bloco 6 & Bloco 7 & Bloco 9 & Bloco 11 & Bloco 12 & Bloco 14 & Bloco 15 \\
& & & & & & & & \\
Peso Erlen. vazio (g) & 199.50 & 213.50 & 183.00 & 219.00 & 213.00 & 189.50 & 206.00 & 189.50 \\
Peso Erlen. esteril. (g) & 301.00 & 315.50 & 285.00 & 319.50 & 313.00 & 289.50 & 306.00 & 289.50 \\
Peso Erlen. c/ inóc. (g) & 302.50 & 318.00 & 286.00 & 322.00 & 314.50 & 290.50 & 308.00 & 291.00 \\
Peso Erlen após inc. (g) & 295.00 & 310.50 & 278.50 & 315.50 & 308.00 & 284.50 & 304.00 & 284.50 \\
pH inicial & 5.60 & 5.60 & 5.60 & 5.60 & 5.60 & 5.60 & 5.60 & 5.60 \\
pH final & 4.08 & 4.11 & 3.78 & 4.09 & 4.04 & 3.79 & 4.05 & 3.97 \\
ART final (\%) & 0.4704 & 0.4354 & 0.4684 & 0.4518 & 0.2677 & 0.3473 & 0.2974 & 0.3312 \\
Etanol (v/v) & 6.28 & 6.56 & 5.86 & 6.28 & 6.00 & 6.28 & 6.86 & 6.14 \\
Etanol (g/g) & 5.00 & 5.22 & 4.66 & 5.00 & 4.78 & 5.00 & 5.44 & 4.88 \\
Peso Massa Seca (g) & 0.00988 & 0.00724 & 0.01115 & 0.01011 & 0.00643 & 0.01008 & 0.00993 & 0.01066 \\
ART meio 3 (\%) & 13.3636 & 13.2500 & 12.9911 & 13.2589 & 14.1772 & 13.8075 & 13.7551 & 14.0157 \\
\hline
\end{tabular}




\section{TRATAMENTO 13}

\begin{tabular}{|lrrrrrrrr|}
\hline PROPAGAÇÃO & Bloco 2 & Bloco 3 & Bloco 4 & Bloco 5 & Bloco 7 & Bloco 13 & Bloco 14 & Bloco 15 \\
& & & & & & & & \\
Peso Erlen. vazio (g) & 221.00 & 220.00 & 192.50 & 191.50 & 221.00 & 190.00 & 190.00 & 186.50 \\
Peso Erlen. esteril. (g) & 422.00 & 420.00 & 395.00 & 395.50 & 421.50 & 390.00 & 390.00 & 386.50 \\
Peso Erlen. c/ inóc. (g) & 434.00 & 432.50 & 405.50 & 408.50 & 434.50 & 403.00 & 403.00 & 398.50 \\
Peso Erlen após inc. (g) & 425.00 & 423.50 & 396.50 & 400.00 & 426.00 & 394.00 & 395.00 & 388.00 \\
pH inicial & 5.60 & 5.60 & 5.60 & 5.60 & 5.60 & 5.60 & 5.60 & 5.60 \\
pH final & 3.84 & 3.90 & 4.04 & 3.94 & 3.83 & 3.71 & 3.73 & 3.76 \\
Viabilidade (\%) & 96.41 & 98.13 & 97.19 & 98.87 & 98.89 & 96.96 & 98.71 & 96.54 \\
ART final (\%) & 0.1917 & 0.2000 & 0.2945 & 0.2705 & 0.2825 & 0.2045 & 0.2051 & 0.2136 \\
Etanol (v/v) & 4.90 & 4.48 & 4.48 & 4.62 & 4.76 & 4.76 & 5.04 & 4.76 \\
Etanol (g/g) & 3.88 & 3.56 & 3.56 & 3.66 & 3.78 & 3.78 & 4.00 & 3.78 \\
Peso Massa Seca (g) & 0.00632 & 0.00528 & 0.00534 & 0.00528 & 0.00392 & 0.00594 & 0.00660 & 0.00550 \\
Células/ml 108 & 2.7 & 2.9 & 2.4 & 1.2 & 2.9 & 2.5 & 3.1 & 2.3 \\
\hline
\end{tabular}

\begin{tabular}{|lrrrrrrrr|}
\hline FERMENTAÇÃO & Bloco 2 & Bloco 3 & Bloco 4 & Bloco 5 & Bloco 7 & Bloco 13 & Bloco 14 & Bloco 15 \\
Peso Erlen. vazio (g) & 184.00 & 183.00 & 191.00 & 212.50 & 189.50 & 209.00 & 208.50 & 191.50 \\
Peso Erlen. esteril. (g) & 284.50 & 283.50 & 295.00 & 316.00 & 292.00 & 310.00 & 310.50 & 291.50 \\
Peso Erlen. c/ inóc. (g) & 287.00 & 285.50 & 296.00 & 317.00 & 294.00 & 312.00 & 312.00 & 292.50 \\
Peso Erlen após inc. (g) & 281.00 & 278.50 & 290.00 & 311.00 & 287.00 & 305.00 & 304.50 & 286.00 \\
pH inicial & 5.60 & 5.60 & 5.60 & 5.60 & 5.60 & 5.60 & 5.60 & 5.60 \\
pH final & 3.87 & 3.86 & 3.89 & 3.89 & 3.63 & 3.77 & 3.76 & 3.82 \\
ART final (\%) & 0.2941 & 0.2967 & 0.4801 & 0.4545 & 0.4342 & 0.2952 & 0.2775 & 0.3143 \\
Etanol (v/v) & 6.42 & 5.86 & 5.86 & 6.28 & 5.86 & 6.42 & 6.42 & 6.56 \\
Etanol (g/g) & 5.10 & 4.66 & 4.66 & 5.00 & 4.66 & 5.10 & 5.10 & 5.22 \\
Peso Massa Seca (g) & 0.00922 & 0.01178 & 0.00979 & 0.00934 & 0.00947 & 0.01046 & 0.00967 & 0.01010 \\
ART meio 3 (\%) & 14.3644 & 14.1224 & 13.7712 & 13.3636 & 12.9911 & 12.2909 & 13.7551 & 14.0157 \\
\hline
\end{tabular}




\section{TRATAMENTO 14}

\begin{tabular}{|c|c|c|c|c|c|c|c|c|}
\hline PROPAGAÇÃO & Bloco 1 & Eloco 3 & Bloco 6 & Bloco 7 & Bloco 9 & Bloco 10 & Bloce 13 & Bloco 14 \\
\hline Peso Erlen. vazio (g) & 187.00 & 194.00 & 184.50 & 209.00 & 190.50 & 194.50 & 205.00 & 205.00 \\
\hline Peso Erlen. esteril. (g) & 387.00 & 394.00 & 389.50 & 410.00 & 392.00 & 396.50 & 405.00 & 405.00 \\
\hline Peso Erlen. c/ inóc. (g) & 398.50 & 406.50 & 400.00 & 423.50 & 404.00 & 408.00 & 415.50 & 419.00 \\
\hline Peso Erlen após inc. (g) & 391.00 & 397.50 & 392.50 & 414.50 & 394.50 & 399.00 & 405.50 & 411.00 \\
\hline pH inicial & 5.60 & 5.60 & 5.60 & 5.60 & 5.60 & 5.60 & 5.60 & 5.60 \\
\hline $\mathrm{pH}$ final & 3.84 & 3.88 & 4.00 & 3.77 & 4.09 & 4.01 & 3.72 & 3.68 \\
\hline Viabilidade (\%) & 98.02 & 98.22 & 98.16 & 99.26 & 97.61 & 98.04 & 95.21 & 98.94 \\
\hline ART final (\%) & 0.2141 & 0.2082 & 0.3229 & 0.2915 & 0.3460 & 0.2980 & 0.1891 & 0.2163 \\
\hline Etanol (v/v) & 4.48 & 5.04 & 4.48 & 4.76 & 4.48 & 4.48 & 4.48 & 4.76 \\
\hline Etanol (g/g) & 3.56 & 4.00 & 3.56 & 3.78 & 3.56 & 3.56 & 3.56 & 3.78 \\
\hline Peso Massa Seca (g) & 0.00568 & 0.00591 & 0.00456 & 0.00529 & 0.00554 & 0.00545 & 0.00497 & 0.00613 \\
\hline Células $/ \mathrm{ml} \quad 10^{8}$ & 4.4 & 2.7 & 2.9 & 3.7 & 1.8 & - & 3.4 & 3.7 \\
\hline
\end{tabular}

\begin{tabular}{|c|c|c|c|c|c|c|c|c|}
\hline FERMENTAÇÃO & Bloco 1 & Bloco 3 & Bloco 6 & Bloco 7 & Bloco 9 & Bloco 10 & Bloco 13 & Bloco 14 \\
\hline Peso Erlen. vazio (g) & 191.00 & 213.50 & 204.50 & 190.00 & 189.00 & 189.50 & 209.00 & 219.00 \\
\hline Peso Erlen. esteril. (g) & 291.00 & 315.00 & 308.00 & 292.00 & 291.00 & 290.50 & 310.00 & 319.00 \\
\hline Peso Erlen. c/ inóc. (g) & 293.00 & 317.50 & 310.00 & 294.00 & 292.00 & 291.50 & 312.00 & 321.00 \\
\hline Peso Erlen após inc. (g) & 286.20 & 310.50 & 303.50 & 287.00 & 284.50 & 284.50 & 305.00 & 313.50 \\
\hline pH inicial & 5.60 & 5.60 & 5.60 & 5.60 & 5.60 & 5.60 & 5.60 & 5.60 \\
\hline pH final & 4.03 & 4.05 & 4.12 & 3.78 & 4.17 & 4.17 & 3.77 & 3.94 \\
\hline ART final (\%) & 0.3170 & 0.3050 & 0.4708 & 0.4842 & 0.4610 & 0.4095 & 0.2992 & 0.2951 \\
\hline Etanol (v/v) & 6.56 & 6.42 & 6.28 & 5.58 & 5.86 & 6.00 & 6.42 & 6.86 \\
\hline Etanol $(g / g)$ & 5.22 & 5.10 & 5.00 & 4.44 & 4.66 & 4.78 & 5.10 & 5.44 \\
\hline Peso Massa Seca (g) & 0.00941 & 0.01125 & 0.00819 & 0.01061 & 0.00889 & 0.00915 & 0.00961 & 0.00933 \\
\hline ART meio $3(\%)$ & 14.4726 & 14.1224 & 13.2500 & 12.9911 & 13.2589 & 15.0000 & 12.2909 & 13.7551 \\
\hline
\end{tabular}


TRATAMENTO 15

\begin{tabular}{|lrrrrrrrr|}
\hline PROPAGAÇÃO & Bloco 1 & Bloco 2 & Bloco 4 & Bloco 7 & Bloco 10 & Bloco 11 & Bloco 12 & Bloco 14 \\
& & & & & & & & \\
Peso Erlen. vazio (g) & 204.50 & 205.00 & 221.50 & 187.00 & 186.50 & 186.50 & 187.00 & 221.00 \\
Peso Erlen. esteril. (g) & 405.00 & 405.50 & 423.50 & 389.00 & 388.00 & 386.50 & 387.00 & 422.00 \\
Peso Erlen. c/ inóc. (g) & 418.50 & 417.50 & 432.00 & 401.00 & 400.00 & 398.00 & 400.00 & 433.50 \\
Peso Erlen após inc. (g) & 410.00 & 408.50 & 423.00 & 393.00 & 390.00 & 389.00 & 389.50 & 425.50 \\
pH inicial & 5.60 & 5.60 & 5.60 & 5.60 & 5.60 & 5.60 & 5.60 & 5.60 \\
pH final & 3.92 & 3.90 & 4.07 & 3.81 & 4.00 & 3.90 & 3.74 & 3.70 \\
Viabilidade (\%) & 98.76 & 98.48 & 98.05 & 99.17 & 96.96 & 98.70 & 98.04 & 97.70 \\
ART final (\%) & 0.1983 & 0.1896 & 0.3104 & 0.2724 & 0.1889 & 0.2310 & 0.1904 & 0.1990 \\
Etanol (v/v) & 4.48 & 4.76 & 4.62 & 4.90 & 4.83 & 4.90 & 4.90 & 5.04 \\
Etanol (g/g) & 3.56 & 3.78 & 3.66 & 3.88 & 3.83 & 3.88 & 3.88 & 4.00 \\
Peso Massa Seca (g) & 0.00638 & $\mathbf{0 . 0 0 6 4 8}$ & 0.00533 & 0.00517 & 0.00603 & 0.00567 & 0.00476 & 0.00617 \\
Células/ml 10 & 3.9 & 4.3 & 1.4 & 3.3 & 4.9 & 2.4 & 1.9 & 4.4 \\
\hline
\end{tabular}

\begin{tabular}{|lrrrrrrrr|}
\hline FERMENTAÇÃO & Bloco 1 & Bloco 2 & Bloco 4 & Bloco 7 & Bloco 10 & Bloco 11 & Bloco 12 & Bloco 14 \\
& & & & & & & & \\
Peso Erlen. vazio (g) & 214.00 & 210.00 & 204.00 & 214.50 & 218.00 & 219.00 & 190.50 & 191.00 \\
Peso Erlen. esteril. (g) & 316.00 & 310.50 & 310.00 & 317.00 & 320.00 & 320.00 & 290.50 & 291.00 \\
Peso Erlen. c/ inóc. (g) & 317.50 & 313.00 & 311.00 & 320.00 & 321.50 & 321.00 & 292.00 & 292.50 \\
Peso Erlen após inc. (g) & 312.00 & 306.50 & 305.00 & 311.50 & 315.50 & 314.00 & 286.00 & 286.00 \\
pH inicial & 5.60 & 5.60 & 5.60 & 5.60 & 5.60 & 5.60 & 5.60 & 5.60 \\
pH final & 3.98 & 3.94 & 4.10 & 3.68 & 4.19 & 4.16 & 3.75 & 3.90 \\
ART final (\%) & 0.3021 & 0.2962 & 0.4779 & 0.4421 & 0.3167 & 0.2660 & 0.3180 & 0.2819 \\
Etanol (v/v) & 6.56 & 6.42 & 5.86 & 6.14 & 6.56 & 6.42 & 6.56 & 6.70 \\
Etanol (g/g) & 5.22 & 5.10 & 4.66 & 4.88 & 5.22 & 5.10 & 5.22 & 5.34 \\
Peso Massa Seca (g) & 0.01045 & 0.01048 & 0.00921 & 0.01067 & 0.01059 & 0.00722 & 0.01096 & 0.01016 \\
ART meio 3 (\%) & 14.4726 & 14.3644 & 13.7712 & 12.9911 & 15.0000 & 14.1772 & 13.8075 & 13.7551 \\
\hline
\end{tabular}




\section{APÊNDICE 3}

DADOS DE CRESCIMENTO CELULAR

\begin{tabular}{|c|c|c|c|}
\hline \multicolumn{4}{|c|}{ TRATAMENTO 1 } \\
\hline Tempo & $\begin{array}{c}\text { Absor- } \\
\text { bância }\end{array}$ & $\begin{array}{c}\text { Concent. } \\
\text { celular }\end{array}$ & $\begin{array}{c}\text { logaritmo } \\
\text { neperiano }\end{array}$ \\
\hline 0 & 0.237 & 0.2197 & -1.5155 \\
1 & 0.240 & 0.2213 & -1.5082 \\
2 & 0.246 & 0.2244 & -1.4943 \\
3 & 0.250 & 0.2265 & -1.4850 \\
4 & 0.255 & 0.2290 & -1.4740 \\
5 & 0.266 & 0.2347 & -1.4494 \\
6 & 0.267 & 0.2352 & -1.4473 \\
7 & 0.270 & 0.2368 & -1.4405 \\
8 & 0.291 & 0.2476 & -1.3959 \\
9 & 0.313 & 0.2590 & -1.3509 \\
10 & 0.336 & 0.2709 & -1.3060 \\
11 & 0.374 & 0.2905 & -1.2362 \\
12 & 0.394 & 0.3009 & -1.2010 \\
13 & 0.441 & 0.3251 & -1.1236 \\
14 & 0.472 & 0.3412 & -1.0753 \\
15 & 0.505 & 0.3582 & -1.0267 \\
16 & 0.544 & 0.3784 & -0.9718 \\
17 & 0.601 & 0.4078 & -0.8970 \\
18 & 0.634 & 0.4249 & -0.8559 \\
19 & 0.679 & 0.4481 & -0.8027 \\
20 & 0.719 & 0.4688 & -0.7576 \\
\hline
\end{tabular}

\begin{tabular}{|c|c|c|c|}
\hline \multicolumn{4}{|c|}{ TRATAMENTO 2 } \\
\hline Tempo & $\begin{array}{c}\text { Absor- } \\
\text { bância }\end{array}$ & $\begin{array}{c}\text { Concent. } \\
\text { celular }\end{array}$ & $\begin{array}{c}\text { logaritmo } \\
\text { neperiano }\end{array}$ \\
\hline 0 & 0.201 & 0.1426 & -1.9477 \\
1 & 0.214 & 0.1491 & -1.9031 \\
2 & 0.215 & 0.1496 & -1.8998 \\
3 & 0.234 & 0.1592 & -1.8376 \\
4 & 0.239 & 0.1667 & -1.7916 \\
5 & 0.249 & 0.1667 & -1.7916 \\
6 & 0.269 & 0.1768 & -1.7327 \\
7 & 0.297 & 0.1908 & -1.6565 \\
8 & 0.322 & 0.2034 & -1.5926 \\
9 & 0.372 & 0.2285 & -1.4762 \\
10 & 0.401 & 0.2431 & -1.4143 \\
11 & 0.455 & 0.2702 & -1.3086 \\
12 & 0.470 & 0.2777 & -1.2812 \\
13 & 0.524 & 0.3049 & -1.1878 \\
14 & 0.563 & 0.3245 & -1.1255 \\
15 & 0.600 & 0.3431 & -1.0697 \\
16 & 0.658 & 0.3721 & -0.9886 \\
17 & 0.660 & 0.3732 & -0.9856 \\
18 & 0.673 & 0.3797 & -0.9684 \\
19 & 0.728 & 0.4074 & -0.8980 \\
20 & 0.720 & 0.4033 & -0.9081 \\
\hline
\end{tabular}

\begin{tabular}{|c|c|c|c|}
\hline \multicolumn{4}{|c|}{ TRATAMENTO 3 } \\
\hline Tempo & $\begin{array}{c}\text { Absor- } \\
\text { bância }\end{array}$ & $\begin{array}{c}\text { Concent. } \\
\text { celular }\end{array}$ & $\begin{array}{c}\text { logarítmo } \\
\text { neperiano }\end{array}$ \\
\hline 0 & 0.234 & 0.1760 & -1.7373 \\
1 & 0.237 & 0.1774 & -1.7293 \\
2 & 0.239 & 0.1784 & -1.7237 \\
3 & 0.246 & 0.1817 & -1.7054 \\
4 & 0.247 & 0.1821 & -1.7032 \\
5 & 0.263 & 0.1898 & -1.6618 \\
6 & 0.277 & 0.1964 & -1.6276 \\
7 & 0.303 & 0.2088 & -1.5664 \\
8 & 0.337 & 0.2250 & -1.4917 \\
9 & 0.376 & 0.2436 & -1.4122 \\
10 & 0.411 & 0.2602 & -1.3463 \\
11 & 0.426 & 0.2673 & -1.3194 \\
12 & 0.448 & 0.2778 & -1.2809 \\
13 & 0.461 & 0.2840 & -1.2588 \\
14 & 0.498 & 0.3016 & -1.1987 \\
15 & 0.531 & 0.3173 & -1.1479 \\
16 & 0.555 & 0.3287 & -1.1126 \\
17 & 0.594 & 0.3473 & -1.0576 \\
18 & 0.616 & 0.3578 & -1.0278 \\
19 & 0.670 & 0.3835 & -0.9584 \\
20 & 0.639 & 0.3687 & -0.9978 \\
\hline
\end{tabular}

\begin{tabular}{|c|c|c|c|}
\hline \multicolumn{4}{|c|}{ TRATAMENTO 4 } \\
\hline Tempo & $\begin{array}{c}\text { Absor- } \\
\text { bância }\end{array}$ & $\begin{array}{c}\text { Concent. } \\
\text { celular }\end{array}$ & $\begin{array}{c}\text { logarítmo } \\
\text { neperiano }\end{array}$ \\
\hline 0 & 0.220 & 0.1996 & -1.6114 \\
1 & 0.222 & 0.2007 & -1.6059 \\
2 & 0.225 & 0.2022 & -1.5985 \\
3 & 0.227 & 0.2033 & -1.5931 \\
4 & 0.229 & 0.2044 & -1.5877 \\
5 & 0.230 & 0.2049 & -1.5852 \\
6 & 0.231 & 0.2054 & -1.5828 \\
7 & 0.245 & 0.2129 & -1.5469 \\
8 & 0.256 & 0.2187 & -1.5201 \\
9 & 0.257 & 0.2192 & -1.5178 \\
10 & 0.260 & 0.2208 & -1.5105 \\
11 & 0.282 & 0.2325 & -1.4589 \\
12 & 0.300 & 0.2421 & -1.4184 \\
13 & 0.327 & 0.2564 & -1.3610 \\
14 & 0.341 & 0.2638 & -1.3326 \\
15 & 0.370 & 0.2792 & -1.2758 \\
16 & 0.373 & 0.2808 & -1.2701 \\
17 & 0.402 & 0.2962 & -1.2167 \\
18 & 0.423 & 0.3074 & -1.1796 \\
19 & 0.445 & 0.3191 & -1.1423 \\
20 & 0.462 & 0.3281 & -1.1144 \\
\hline
\end{tabular}




\begin{tabular}{|c|c|c|c|}
\hline \multicolumn{4}{|c|}{ TRATAMENTO 5 } \\
\hline Tempo & $\begin{array}{c}\text { Absor- } \\
\text { bância }\end{array}$ & $\begin{array}{c}\text { Concent. } \\
\text { celular }\end{array}$ & $\begin{array}{l}\text { logaritmo } \\
\text { neperiano }\end{array}$ \\
\hline 0 & 0.224 & 0.2117 & -1.5526 \\
1 & 0.243 & 0.2212 & -1.5087 \\
2 & 0.249 & 0.2242 & -1.4952 \\
3 & 0.252 & 0.2257 & -1.4885 \\
4 & 0.259 & 0.2292 & -1.4732 \\
5 & 0.272 & 0.2357 & -1.4452 \\
6 & 0.282 & 0.2407 & -1.4242 \\
7 & 0.307 & 0.2532 & -1.3736 \\
8 & 0.356 & 0.2777 & -1.2812 \\
9 & 0.374 & 0.2867 & -1.2493 \\
10 & 0.428 & 0.3137 & -1.1593 \\
11 & 0.458 & 0.3286 & -1.1129 \\
12 & 0.501 & 0.3501 & -1.0495 \\
13 & 0.533 & 0.3661 & -1.0048 \\
14 & 0.569 & 0.3841 & -0.9569 \\
15 & 0.607 & 0.4031 & -0.9086 \\
16 & 0.641 & 0.4201 & -0.8673 \\
17 & 0.658 & 0.4286 & -0.8472 \\
18 & 0.678 & 0.4386 & -0.8242 \\
19 & 0.724 & 0.4616 & -0.7731 \\
20 & 0.738 & 0.4686 & -0.7580 \\
\hline
\end{tabular}

\begin{tabular}{|c|c|c|c|}
\hline \multicolumn{4}{|c|}{ TRATAMENTO 6 } \\
\hline Tempo & $\begin{array}{c}\text { Absor- } \\
\text { bância }\end{array}$ & $\begin{array}{c}\text { Concent. } \\
\text { celular }\end{array}$ & $\begin{array}{l}\text { logarítmo } \\
\text { neperiano }\end{array}$ \\
\hline 0 & 0.256 & 0.2300 & -1.4697 \\
1 & 0.269 & 0.2360 & -1.4439 \\
2 & 0.277 & 0.2397 & -1.4284 \\
3 & 0.294 & 0.2476 & -1.3959 \\
4 & 0.295 & 0.2480 & -1.3943 \\
5 & 0.326 & 0.2624 & -1.3379 \\
6 & 0.357 & 0.2768 & -1.2845 \\
7 & 0.374 & 0.2846 & -1.2567 \\
8 & 0.423 & 0.3073 & -1.1799 \\
9 & 0.431 & 0.3110 & -1.1680 \\
10 & 0.490 & 0.3384 & -1.0835 \\
11 & 0.524 & 0.3541 & -1.0382 \\
12 & 0.557 & 0.3694 & -0.9959 \\
13 & 0.594 & 0.3866 & -0.9504 \\
14 & 0.638 & 0.4070 & -0.8989 \\
15 & 0.663 & 0.4186 & -0.8708 \\
16 & 0.680 & 0.4264 & -0.8524 \\
17 & 0.716 & 0.4431 & -0.8140 \\
18 & 0.739 & 0.4538 & -0.7901 \\
19 & 0.778 & 0.4718 & -0.7512 \\
20 & 0.800 & 0.4820 & -0.7298 \\
\hline
\end{tabular}

\begin{tabular}{|c|c|c|c|}
\hline \multicolumn{4}{|c|}{ TRATAMENTO 7 } \\
\hline Tempo & $\begin{array}{c}\text { Absor- } \\
\text { bância }\end{array}$ & $\begin{array}{c}\text { Concent. } \\
\text { celular }\end{array}$ & $\begin{array}{l}\text { logarítmo } \\
\text { neperiano }\end{array}$ \\
\hline 0 & 0.280 & 0.2509 & -1.3827 \\
1 & 0.281 & 0.2514 & -1.3807 \\
2 & 0.292 & 0.2570 & -1.3587 \\
3 & 0.321 & 0.2719 & -1.3023 \\
4 & 0.325 & 0.2739 & -1.2950 \\
5 & 0.328 & 0.2754 & -1.2895 \\
6 & 0.335 & 0.2790 & -1.2765 \\
7 & 0.360 & 0.2918 & -1.2317 \\
8 & 0.385 & 0.3046 & -1.1888 \\
9 & 0.412 & 0.3185 & -1.1441 \\
10 & 0.423 & 0.3241 & -1.1267 \\
11 & 0.458 & 0.3420 & -1.0729 \\
12 & 0.471 & 0.3487 & -1.0535 \\
13 & 0.533 & 0.3804 & -0.9665 \\
14 & 0.566 & 0.3973 & -0.9231 \\
15 & 0.600 & 0.4147 & -0.8802 \\
16 & 0.655 & 0.4429 & -0.8144 \\
17 & 0.674 & 0.4526 & -0.7927 \\
18 & 0.712 & 0.4721 & -0.7506 \\
19 & 0.729 & 0.4808 & -0.7323 \\
20 & 0.844 & 0.5396 & -0.6169 \\
\hline
\end{tabular}

\begin{tabular}{|c|c|c|c|}
\hline \multicolumn{4}{|c|}{ TRATAMENT 8 } \\
\hline Tempo & $\begin{array}{c}\text { Absor- } \\
\text { bância }\end{array}$ & $\begin{array}{c}\text { Concent. } \\
\text { celular }\end{array}$ & $\begin{array}{l}\text { logarítmo } \\
\text { neperiano }\end{array}$ \\
\hline 0 & 0.242 & 0.1750 & -1.7430 \\
1 & 0.248 & 0.1778 & -1.7271 \\
2 & 0.251 & 0.1792 & -1.7193 \\
3 & 0.258 & 0.1824 & -1.6896 \\
4 & 0.263 & 0.1846 & -1.6896 \\
5 & 0.270 & 0.1878 & -1.6724 \\
6 & 0.284 & 0.1942 & -1.6389 \\
7 & 0.285 & 0.1947 & -1.6363 \\
8 & 0.343 & 0.2212 & -1.5087 \\
9 & 0.354 & 0.2262 & -1.4863 \\
10 & 0.360 & 0.2290 & -1.4740 \\
11 & 0.409 & 0.2514 & -1.3807 \\
12 & 0.424 & 0.2582 & -1.3540 \\
13 & 0.425 & 0.2587 & -1.3521 \\
14 & 0.473 & 0.2806 & -1.2708 \\
15 & 0.496 & 0.2911 & -1.2341 \\
16 & 0.509 & 0.2971 & -1.2137 \\
17 & 0.540 & 0.3112 & -1.1673 \\
18 & 0.565 & 0.3227 & -1.1310 \\
19 & 0.610 & 0.3432 & -1.0694 \\
20 & 0.671 & 0.3711 & -0.9913 \\
\hline
\end{tabular}




\begin{tabular}{|c|c|c|l|}
\hline \multicolumn{4}{|c|}{ TRATAMENTO 9 } \\
\hline Tempo & $\begin{array}{c}\text { Absor- } \\
\text { bância }\end{array}$ & $\begin{array}{c}\text { Concent. } \\
\text { celular }\end{array}$ & $\begin{array}{l}\text { logaritmo } \\
\text { neperiano }\end{array}$ \\
\hline 0 & 0.244 & 0.1721 & -1.7597 \\
1 & 0.245 & 0.1726 & -1.7568 \\
2 & 0.259 & 0.1793 & -1.7187 \\
3 & 0.274 & 0.1864 & -1.6799 \\
4 & 0.276 & 0.1874 & -1.6745 \\
5 & 0.278 & 0.1884 & -1.6692 \\
6 & 0.291 & 0.1946 & -1.6368 \\
7 & 0.314 & 0.2055 & -1.5823 \\
8 & 0.327 & 0.2118 & -1.5521 \\
9 & 0.349 & 0.2223 & -1.5037 \\
10 & 0.378 & 0.2361 & -1.4435 \\
11 & 0.406 & 0.2495 & -1.3883 \\
12 & 0.416 & 0.2543 & -1.3692 \\
13 & 0.445 & 0.2682 & -1.3160 \\
14 & 0.452 & 0.2715 & -1.3038 \\
15 & 0.494 & 0.2916 & -1.2324 \\
16 & 0.524 & 0.3059 & -1.1845 \\
17 & 0.546 & 0.3164 & -1.1507 \\
18 & 0.588 & 0.3365 & -1.0892 \\
19 & 0.600 & 0.3422 & -1.0724 \\
20 & 0.620 & 0.3518 & -1.0447 \\
\hline
\end{tabular}

\begin{tabular}{|c|c|c|c|}
\hline \multicolumn{4}{|c|}{ TRATAMENTO 10 } \\
\hline Tempo & $\begin{array}{c}\text { Absor- } \\
\text { bância }\end{array}$ & $\begin{array}{c}\text { Concent. } \\
\text { celular }\end{array}$ & $\begin{array}{l}\text { logarítmo } \\
\text { neperiano }\end{array}$ \\
\hline 0 & 0.283 & 0.2047 & -1.5862 \\
1 & 0.286 & 0.2060 & -1.5799 \\
2 & 0.289 & 0.2074 & -1.5731 \\
3 & 0.292 & 0.2087 & -1.5669 \\
4 & 0.295 & 0.2101 & -1.5602 \\
5 & 0.299 & 0.2119 & -1.5516 \\
6 & 0.308 & 0.2160 & -1.5325 \\
7 & 0.315 & 0.2191 & -1.5182 \\
8 & 0.335 & 0.2280 & -1.4784 \\
9 & 0.367 & 0.2425 & -1.4168 \\
10 & 0.386 & 0.2510 & -1.3823 \\
11 & 0.410 & 0.2618 & -1.3402 \\
12 & 0.417 & 0.2650 & -1.3280 \\
13 & 0.440 & 0.2753 & -1.2899 \\
14 & 0.474 & 0.2906 & -1.2358 \\
15 & 0.487 & 0.2964 & -1.2160 \\
16 & 0.516 & 0.3094 & -1.1731 \\
17 & 0.545 & 0.3225 & -1.1317 \\
18 & 0.610 & 0.3517 & -1.0450 \\
19 & 0.641 & 0.3656 & -1.0062 \\
20 & 0.644 & 0.3669 & -1.0027 \\
\hline
\end{tabular}

\begin{tabular}{|c|c|c|c|}
\hline \multicolumn{4}{|c|}{ TRATAMENT 11 } \\
\hline Tempo & $\begin{array}{c}\text { Absor- } \\
\text { bância }\end{array}$ & $\begin{array}{c}\text { Concent. } \\
\text { celular }\end{array}$ & $\begin{array}{l}\text { logaritmo } \\
\text { neperiano }\end{array}$ \\
\hline 0 & 0.328 & 0.2549 & -1.3669 \\
1 & 0.335 & 0.2579 & -1.3552 \\
2 & 0.338 & 0.2592 & -1.3502 \\
3 & 0.353 & 0.2656 & -1.3258 \\
4 & 0.359 & 0.2681 & -1.3164 \\
5 & 0.366 & 0.2711 & -1.3053 \\
6 & 0.377 & 0.2758 & -1.2881 \\
7 & 0.390 & 0.2814 & -1.2680 \\
8 & 0.414 & 0.2916 & -1.2324 \\
9 & 0.458 & 0.3104 & -1.1699 \\
10 & 0.494 & 0.3257 & -1.1218 \\
11 & 0.519 & 0.3364 & -1.0895 \\
12 & 0.550 & 0.3496 & -1.0510 \\
13 & 0.575 & 0.3603 & -1.0208 \\
14 & 0.620 & 0.3795 & -0.9689 \\
15 & 0.637 & 0.3867 & -0.9501 \\
16 & 0.692 & 0.4102 & -0.8911 \\
17 & 0.729 & 0.4260 & -0.8533 \\
18 & 0.756 & 0.4375 & -0.8267 \\
19 & 0.765 & 0.4413 & -0.8180 \\
20 & 0.836 & 0.4716 & -0.7516 \\
\hline
\end{tabular}

\begin{tabular}{|c|c|c|c|}
\hline \multicolumn{4}{|c|}{ TRATAMENTO 12 } \\
\hline Tempo & $\begin{array}{c}\text { Absor- } \\
\text { bância }\end{array}$ & $\begin{array}{c}\text { Concent. } \\
\text { celular }\end{array}$ & $\begin{array}{l}\text { logarítmo } \\
\text { neperiano }\end{array}$ \\
\hline 0 & 0.353 & 0.2785 & -1.2783 \\
1 & 0.357 & 0.2803 & -1.2719 \\
2 & 0.358 & 0.2807 & -1.2705 \\
3 & 0.371 & 0.2866 & -1.2497 \\
4 & 0.382 & 0.2916 & -1.2324 \\
5 & 0.393 & 0.2965 & -1.2157 \\
6 & 0.412 & 0.3051 & -1.1871 \\
7 & 0.418 & 0.3078 & -1.1783 \\
8 & 0.438 & 0.3168 & -1.1495 \\
9 & 0.464 & 0.3285 & -1.1132 \\
10 & 0.489 & 0.3398 & -1.0794 \\
11 & 0.518 & 0.3528 & -1.0419 \\
12 & 0.559 & 0.3713 & -0.9907 \\
13 & 0.583 & 0.3821 & -0.9621 \\
14 & 0.611 & 0.3947 & -0.9296 \\
15 & 0.616 & 0.3970 & -0.9238 \\
16 & 0.678 & 0.4249 & -0.8559 \\
17 & 0.719 & 0.4434 & -0.8133 \\
18 & 0.748 & 0.4565 & -0.7842 \\
19 & 0.751 & 0.4578 & -0.7813 \\
20 & 0.864 & 0.5087 & -0.6759 \\
\hline
\end{tabular}




\begin{tabular}{|c|c|c|c|}
\hline \multicolumn{4}{|c|}{ TRATAMENT 13 } \\
\hline Tempo & $\begin{array}{c}\text { Absor- } \\
\text { bância }\end{array}$ & $\begin{array}{c}\text { Concent. } \\
\text { celular }\end{array}$ & $\begin{array}{l}\text { logaritmo } \\
\text { neperiano }\end{array}$ \\
\hline 0 & 0.374 & 0.2555 & -1.3645 \\
1 & 0.381 & 0.2585 & -1.3529 \\
2 & 0.389 & 0.2620 & -1.3394 \\
3 & 0.395 & 0.2646 & -1.3295 \\
4 & 0.409 & 0.2707 & -1.3067 \\
5 & 0.421 & 0.2759 & -1.2877 \\
6 & 0.442 & 0.2851 & -1.2549 \\
7 & 0.458 & 0.2920 & -1.2310 \\
8 & 0.469 & 0.2968 & -1.2147 \\
9 & 0.482 & 0.3025 & -1.1957 \\
10 & 0.523 & 0.3203 & -1.1385 \\
11 & 0.533 & 0.3246 & -1.1252 \\
12 & 0.588 & 0.3486 & -1.0538 \\
13 & 0.604 & 0.3555 & -1.0342 \\
14 & 0.671 & 0.3847 & -0.9553 \\
15 & 0.675 & 0.3864 & -0.9509 \\
16 & 0.679 & 0.3882 & -0.9462 \\
17 & 0.683 & 0.3899 & -0.9419 \\
18 & 0.727 & 0.4090 & -0.8940 \\
19 & 0.730 & 0.4103 & -0.8909 \\
20 & 0.775 & 0.4299 & -0.8442 \\
\hline
\end{tabular}

\begin{tabular}{|c|c|c|c|}
\hline \multicolumn{4}{|c|}{ TRATAMENTO 14 } \\
\hline Tempo & $\begin{array}{c}\text { Absor- } \\
\text { bância }\end{array}$ & $\begin{array}{c}\text { Concent. } \\
\text { celular }\end{array}$ & $\begin{array}{l}\text { logarítmo } \\
\text { neperiano }\end{array}$ \\
\hline 0 & 0.367 & 0.2734 & -1.2968 \\
1 & 0.376 & 0.2779 & -1.2805 \\
2 & 0.381 & 0.2804 & -1.2715 \\
3 & 0.389 & 0.2844 & -1.2574 \\
4 & 0.396 & 0.2879 & -1.2451 \\
5 & 0.405 & 0.2924 & -1.2296 \\
6 & 0.411 & 0.2954 & -1.2194 \\
7 & 0.418 & 0.2989 & -1.2076 \\
8 & 0.453 & 0.3165 & -1.1504 \\
9 & 0.456 & 0.3180 & -1.1457 \\
10 & 0.481 & 0.3305 & -1.1071 \\
11 & 0.532 & 0.3560 & -1.0328 \\
12 & 0.550 & 0.3650 & -1.0079 \\
13 & 0.576 & 0.3781 & -0.9726 \\
14 & 0.654 & 0.4171 & -0.8744 \\
15 & 0.659 & 0.4196 & -0.8685 \\
16 & 0.670 & 0.4251 & -0.8554 \\
17 & 0.683 & 0.4316 & -0.8403 \\
18 & 0.697 & 0.4387 & -0.8239 \\
19 & 0.748 & 0.4642 & -0.7674 \\
20 & 0.804 & 0.4922 & -0.7089 \\
\hline
\end{tabular}

\begin{tabular}{|c|c|c|c|}
\hline \multicolumn{4}{|c|}{ TRATAMENTO 15 } \\
\hline Tempo & $\begin{array}{c}\text { Absor- } \\
\text { bância }\end{array}$ & $\begin{array}{c}\text { Concent. } \\
\text { celular }\end{array}$ & $\begin{array}{l}\text { logaritmo } \\
\text { neperiano }\end{array}$ \\
\hline 0 & 0.350 & 0.2500 & -1.3863 \\
1 & 0.352 & 0.2510 & -1.3823 \\
2 & 0.354 & 0.2520 & -1.3783 \\
3 & 0.357 & 0.2535 & -1.3724 \\
4 & 0.360 & 0.2550 & -1.3665 \\
5 & 0.366 & 0.2580 & -1.3548 \\
6 & 0.377 & 0.2635 & -1.3337 \\
7 & 0.420 & 0.2850 & -1.2553 \\
8 & 0.421 & 0.2855 & -1.2535 \\
9 & 0.450 & 0.3000 & -1.2040 \\
10 & 0.472 & 0.3111 & -1.1676 \\
11 & 0.520 & 0.3351 & -1.0933 \\
12 & 0.528 & 0.3391 & -1.0815 \\
13 & 0.580 & 0.3651 & -1.0076 \\
14 & 0.607 & 0.3786 & -0.9713 \\
15 & 0.650 & 0.4001 & -0.9160 \\
16 & 0.661 & 0.4056 & -0.9024 \\
17 & 0.691 & 0.4207 & -0.8658 \\
18 & 0.747 & 0.4487 & -0.8014 \\
19 & 0.748 & 0.4492 & -0.8003 \\
20 & 0.760 & 0.4552 & -0.7870 \\
\hline
\end{tabular}

